\title{
Airborne observations of the Eyjafjalla volcano ash cloud over Europe during air space closure in April and May 2010
}

\author{
U. Schumann ${ }^{1}$, B. Weinzierl ${ }^{1}$, O. Reitebuch ${ }^{1}$, H. Schlager ${ }^{1}$, A. Minikin ${ }^{1}$, C. Forster ${ }^{1}$, R. Baumann ${ }^{1}$, T. Sailer ${ }^{1}$, \\ K. Graf ${ }^{1}$, H. Mannstein ${ }^{1}$, C. Voigt $^{1}$, S. Rahm ${ }^{1}$, R. Simmet ${ }^{1}$, M. Scheibe ${ }^{1}$, M. Lichtenstern ${ }^{1}$, P. Stock ${ }^{1}$, H. Rüba ${ }^{1}$, \\ D. Schäuble ${ }^{1}$, A. Tafferner ${ }^{1}$, M. Rautenhaus ${ }^{1}$, T. Gerz ${ }^{1}$, H. Ziereis ${ }^{1}$, M. Krautstrunk ${ }^{2}$, C. Mallaun ${ }^{2}$, J.-F. Gayet ${ }^{3}$, \\ K. Lieke ${ }^{4}$, K. Kandler ${ }^{4}$, M. Ebert ${ }^{4}$, S. Weinbruch ${ }^{4}$, A. Stohl ${ }^{5}$, J. Gasteiger ${ }^{6}$, S. Groß ${ }^{6}$, V. Freudenthaler ${ }^{6}$, M. Wiegner ${ }^{6}$, \\ A. Ansmann ${ }^{7}$, M. Tesche ${ }^{7}$, H. Olafsson ${ }^{8}$, and K. Sturm ${ }^{9}$ \\ ${ }^{1}$ Deutsches Zentrum für Luft- und Raumfahrt (DLR), Institut für Physik der Atmosphäre, Oberpfaffenhofen, Germany \\ ${ }^{2}$ DLR, Flugexperimente, Oberpfaffenhofen, Germany \\ ${ }^{3}$ Laboratoire de Météorologie Physique UMR 6016/CNRS, Université Blaise Pascal, Clermont-Fd, France \\ ${ }^{4}$ Institut für Angewandte Geowissenschaften, Technische Universität Darmstadt, Germany \\ ${ }^{5}$ Norwegian Institute for Air Research (NILU), Kjeller, Norway \\ ${ }^{6}$ Meteorologisches Institut, Ludwig-Maximilians-Universität, München, Germany \\ ${ }^{7}$ Leibniz Institut für Troposphärenforschung, Leipzig, Germany \\ ${ }^{8}$ University of Iceland and Icelandic Meteorological Office, Reykjavik, Iceland, and Bergen School of Meteorology, \\ Geophysical Institute, University of Bergen, Norway \\ ${ }^{9}$ Deutscher Wetterdienst, Offenbach, Germany
}

Received: 25 August 2010 - Published in Atmos. Chem. Phys. Discuss.: 27 September 2010

Revised: 10 February 2011 - Accepted: 1 March 2011 - Published: 11 March 2011

\begin{abstract}
Airborne lidar and in-situ measurements of aerosols and trace gases were performed in volcanic ash plumes over Europe between Southern Germany and Iceland with the Falcon aircraft during the eruption period of the Eyjafjalla ${ }^{1}$ volcano between 19 April and 18 May 2010. Flight planning and measurement analyses were supported by a refined Meteosat ash product and trajectory model analysis. The volcanic ash plume was observed with lidar directly over the volcano and up to a distance of $2700 \mathrm{~km}$ downwind, and up to $120 \mathrm{~h}$ plume ages. Aged ash layers were between a few $100 \mathrm{~m}$ to $3 \mathrm{~km}$ deep, occurred between 1 and $7 \mathrm{~km}$ altitude, and were typically 100 to $300 \mathrm{~km}$ wide. Particles collected by impactors had diameters up to $20 \mu \mathrm{m}$ diameter, with size and age dependent composition. Ash mass concentrations were derived from optical particle spectrometers for a
\end{abstract}

\section{Correspondence to: U. Schumann} (ulrich.schumann@dlr.de)

\footnotetext{
${ }^{1}$ Also known as Eyjafjallajökull or Eyjafjöll volcano, http://www.britannica.com/EBchecked/topic/1683937/ Eyjafjallajokull-volcano
}

particle density of $2.6 \mathrm{~g} \mathrm{~cm}^{-3}$ and various values of the refractive index (RI, real part: 1.59; 3 values for the imaginary part: 0, 0.004 and 0.008). The mass concentrations, effective diameters and related optical properties were compared with ground-based lidar observations. Theoretical considerations of particle sedimentation constrain the particle diameters to those obtained for the lower RI values. The ash mass concentration results have an uncertainty of a factor of two. The maximum ash mass concentration encountered during the 17 flights with 34 ash plume penetrations was below $1 \mathrm{mg} \mathrm{m}^{-3}$. The Falcon flew in ash clouds up to about $0.8 \mathrm{mg} \mathrm{m}^{-3}$ for a few minutes and in an ash cloud with approximately $0.2 \mathrm{mg} \mathrm{m}^{-3}$ mean-concentration for about one hour without engine damage. The ash plumes were rather dry and correlated with considerable $\mathrm{CO}$ and $\mathrm{SO}_{2}$ increases and $\mathrm{O}_{3}$ decreases. To first order, ash concentration and $\mathrm{SO}_{2}$ mixing ratio in the plumes decreased by a factor of two within less than a day. In fresh plumes, the $\mathrm{SO}_{2}$ and $\mathrm{CO}$ concentration increases were correlated with the ash mass concentration. The ash plumes were often visible slantwise as faint dark layers, even for concentrations below $0.1 \mathrm{mg} \mathrm{m}^{-3}$.

Published by Copernicus Publications on behalf of the European Geosciences Union. 
The large abundance of volatile Aitken mode particles suggests previous nucleation of sulfuric acid droplets. The effective diameters range between 0.2 and $3 \mu \mathrm{m}$ with considerable surface and volume contributions from the Aitken and coarse mode aerosol, respectively. The distal ash mass flux on 2 May was of the order of $500(240-1600) \mathrm{kg} \mathrm{s}^{-1}$. The volcano induced about 10 (2.5-50) Tg of distal ash mass and about 3 (0.6-23) $\mathrm{Tg}$ of $\mathrm{SO}_{2}$ during the whole eruption period. The results of the Falcon flights were used to support the responsible agencies in their decisions concerning air traffic in the presence of volcanic ash.

\section{Introduction}

Iceland's Eyjafjallajökull $\left(63.63^{\circ} \mathrm{N}, 19.62^{\circ} \mathrm{W}, 1666 \mathrm{~m}\right.$ a.s.l $)$ erupted on 14 April 2010 ejecting a volcanic ash (VA) plume over $9 \mathrm{~km}$ a.s.l. into the atmosphere (Sigmundsson et al., 2010). Though the eruption of the Eyjafjalla volcano rates among the mid-sized eruptions (Thordarson and Self, 2003; Mason et al., 2004; Mastin et al., 2009), it had strong impact on aviation over Europe. The eruption occurred in a weather situation with strong westerly winds causing VA to drift within 1-2 days from Iceland toward Central Europe where it resided for several days, as observed, e.g., with ground based lidar (Ansmann et al., 2010; Flentje et al., 2010). Advisories of areas at risk from the volcano plume were issued by the responsible Volcanic Ash Advisory Center (VAAC) of UK Meteorological Office based on model predictions. Based on these advisories, European aviation authorities decided on air space closure. As a consequence, air traffic ceased in 23 European countries and $75 \%$ of the European aerodrome network was closed, with more than 100000 flights cancelled, affecting 10 million passenger journeys, in the time period 14 April to 20 April (as reported by EUROCONTROL). Further incursions of VA over Western Europe caused again airspace closures at various places and periods until 18 May 2010, leading to cancelling of about 7000 more flights.

Never before was such a large and busy air space impacted by a volcanic eruption. Existing regulation required an air space to be closed whenever any VA contamination was expected in the air space without specifying an acceptable safety limit of ash loading (Casadevall, 1993). In desert vicinity regions, such as Saudia Arabia and Southern Morocco, annual mean dust mass levels of $0.2 \mathrm{mg} \mathrm{m}^{-3}$ are not uncommon (Schütz, 1980; Weinzierl et al., 2009). In comparison to desert dust, VA is considered more dangerous because of its lower melting temperature (Casadevall, 1993). During the past $30 \mathrm{yr}$, more than 120 airplanes have inadvertently flown through clouds of VA from erupting volcanoes (Webley and Mastin, 2009). In a few cases, serious engine or aircraft damages have been reported, after a few minutes of flight time in volcanic plume with ash loading of possibly
$2 \mathrm{~g} \mathrm{~m}^{-3}$ as estimated from engine damage analysis (Dunn and Wade, 1994; Przedpelski and Casadevall, 1994). Shortly after the Eyjafjalla eruption, on 20 April 2010, aviation experts agreed preliminarily on new thresholds: $0.2 \mathrm{mg} \mathrm{m}^{-3}$ as the limit below which aircraft may fly without special attention and $2 \mathrm{mg} \mathrm{m}^{-3}$ as a contamination limit above which flights should be avoided. At the end of this volcanic eruption (since $21 \mathrm{May}$ ), areas of low $\left(\leq 2 \mathrm{mg} \mathrm{m}^{-3}\right)$, medium ( 2 to $\left.4 \mathrm{mg} \mathrm{m}^{-3}\right)$ and high $\left(\geq 4 \mathrm{mg} \mathrm{m}^{-3}\right)$ contamination were distinguished (ICAO, 2010).

A few airborne studies have been performed in distal plumes of eruptive volcanoes before, as reviewed in Watson and Oppenheimer (2001). The concentrations and fluxes of trace gases were measured in the Mt. St. Helens plume in 1980 (Bandy et al., 1982; Cronn and Nutmagul, 1982). The $\mathrm{SO}_{2}$ concentration reached $440 \mathrm{nmol} \mathrm{mol}^{-1}$, CO was in the order of $200 \mathrm{nmol} \mathrm{mol}^{-1}$. Source rates of $\mathrm{SO}_{2}$ of up to 10 and $140 \mathrm{~kg} \mathrm{~s}^{-1}$ were derived for Mt. St. Helens and Mt. Redoubt, respectively (Hobbs et al., 1982, 1991). Aircraft and balloonborne measurements were made of trace gases, atmospheric particles, and condensed acid volatiles in the plume of El Chichón volcano, Mexico, in November 1982 (Kotra et al., 1983; Arnold et al., 1990). Hydrogen sulfide was the primary gaseous sulfur species in that plume. Lidar and in-situ measurements were used to determine the cross-sectional area and the fluxes of particles and gases from the Mt. Redoubt Volcano in 1990 (Hobbs et al., 1991). The young stratospheric plume of the Mt. Pinatubo eruption in June 1991 was observed mainly by remote sensing techniques, including airborne lidar (Winker and Osborn, 1992; McCormick et al., 1995). The volcanic eruptions of Mt. Kasatochi $\left(52.2^{\circ} \mathrm{N}\right.$, $175.5^{\circ} \mathrm{W} ; 7$ August 2008) injected about $1.5 \mathrm{Mt} \mathrm{SO}_{2}$ into the atmosphere, the eruption reached up to the stratosphere at $15.2 \mathrm{~km}$ altitude, and resulted in a cancellation or delay of 44 aircraft flights (Schmale et al., 2010). Increased $\mathrm{SO}_{2}$ (and particulate sulfate) concentrations up to $0.5 \mathrm{nmol} \mathrm{mol}^{-1}$ were repeatedly detected in the lower stratosphere above Europe up to 4 months after eruption (Martinsson et al., 2009; Heue et al., 2010b; Jurkat et al., 2010; Mattis et al., 2010; Schmale et al., 2010; Voigt et al., 2010). More recently still, Sarychev $\left(48.1^{\circ} \mathrm{N}, 153.2^{\circ} \mathrm{E} ; 12\right.$ June 2009) erupted in June 2009 injecting around $1.2 \mathrm{Tg}$ of $\mathrm{SO}_{2}$ into the stratosphere (Haywood et al., 2010). In February 2000, a $34 \mathrm{~h}$ aged volcanic cloud from Hekla volcano, Iceland, was incidentally encountered by the DC-8 research aircraft during a larger atmospheric observation experiment (Hunton et al., 2005; Rose et al., 2006). During this flight, the DC-8 sampled various gases (including $\mathrm{SO}_{2}, \mathrm{HCl}$ and $\mathrm{HF}$ ) and particulate properties at $10.4 \mathrm{~km}$ altitude, for about $10 \mathrm{~min}$ inside a cirrus cloud. The $\mathrm{SO}_{2}$ concentration exceeded $1 \mu \mathrm{mol} \mathrm{mol}^{-1}$. Engine damages diagnosed for this case (perhaps for other reasons) were later interpreted as an indication that flying in even minor VA plume remnants may cause major damage to the aircraft (Grindle and Burcham Jr., 2002; Pieri et al., 2002; Grindle and Burcham Jr., 2003). 
The size spectra of ash particles available in the literature were mostly derived from tephra deposited at ground (Rose and Durant, 2009; Webley and Mastin, 2009). Samples taken at ground near the Eyjafjalla indicate particle sizes up to $300 \mu \mathrm{m}$, with more than $50 \%$ mass in particles larger than about $50-150 \mu \mathrm{m}$, varying during the eruption period (IES: Institute of Earth Sciences, University of Iceland, http://www.earthice.hi.is). Most of the large particles sediment out of the ash plume in close vicinity of the volcano.

Only a few airborne measurements of the ash size spectrum and total mass concentrations have been taken inside VA plumes (Hobbs et al., 1982). Particle counters inside the fuselage can measure only small particles $(<2 \mu \mathrm{m})$ because of strong losses at the inlets (Hunton et al., 2005). Larger particles can be measured by particle counters mounted outside the fuselage, but care is needed to separate ash particles from cloud particles. For example, the particle size distribution measured in the Hekla ash plume is dominated by cirrus ice crystals (Rose et al., 2006). The mass concentration of ash particles, which is essential for this study, cannot be directly measured. The volume concentration can be derived from particle number size distributions derived from optical laser aerosol spectrometer measurements (Weinzierl et al., 2009). Such spectrometers count the particles and measure the amount of light scattered by single particles into the collection optics of the particular instruments. The scattered light is a function of particle size, complex refractive index and shape of the particles (Mishchenko and Travis, 1994; Borrmann et al., 2000). The optical properties of VA particles (and their material density) are not well known but can be estimated once the composition of the particles is known (Patterson et al., 1983; Kandler et al., 2009).

The predictions of ash plumes by the UK VAAC are based on a Lagrangian model (Jones et al., 2007), which computes the trajectories of ash particles as a function of ambient winds. The results of this and similar models depend crucially on the volcanological input data, such as plume height, plume depth, mass eruption rate, eruption duration, ash distribution with altitude, and particle size distribution. These inputs must be assigned in real time during an event, often with limited observations (Mastin et al., 2009; Webley and Mastin, 2009). Moreover, the results depend strongly on the meteorological fields used for computing the plume transport, and on particle sedimentation and deposition, and on changes of particle properties during the long-range plume transit. Therefore, observations are important for assessing and improving the quality of the volcanic plume predictions.

Besides the obvious operational implications for aviation, the impact of VA and gaseous emissions on the atmosphere is of high scientific interest. Volcanic emissions may contribute to changes of air composition and cloudiness. Much can be learned about atmospheric chemistry and cirrus formation from well-instrumented flights in VA layers (Hunton et al., 2005; Rose et al., 2006; Durant et al., 2008). We were in particular interested in understanding the plume dispersion,

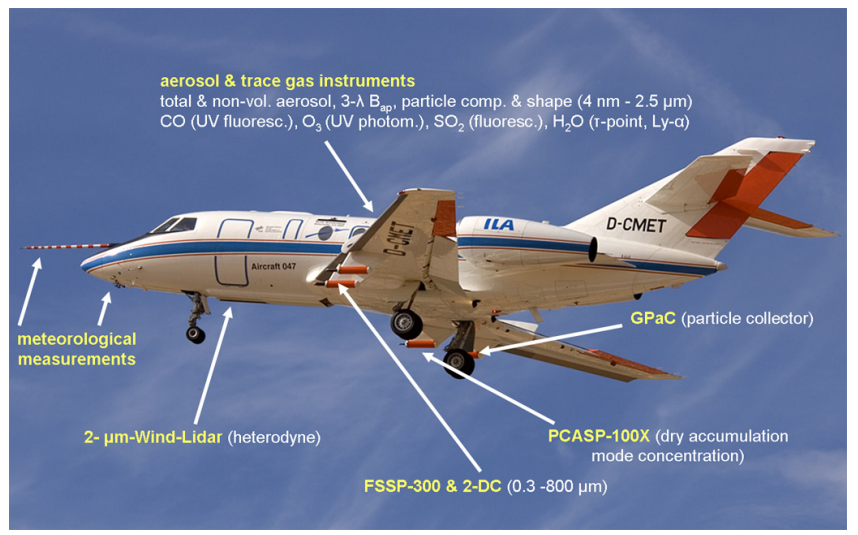

Fig. 1. DLR-research aircraft Falcon and its instrumentation during the volcanic ash flights (Photo: Sergio Domingos, http://www. airliners.net).

the ash particle properties, and the chemical plume composition. The data are of interest also for validation of lidar and satellite based aerosol and sulfur dioxide $\left(\mathrm{SO}_{2}\right)$ observations.

Between 19 April and 18 May 2010, we performed measurements in VA plumes with the research aircraft Falcon of the Deutsches Zentrum für Luft- und Raumfahrt (DLR). The measurements were supported by satellite data analysis, VA model predictions, and weather forecasts. The principal motivation of these measurement flights was to provide as quickly as possible airborne measurements of VA plume properties over Central Europe. The data should provide information useful to assess the VA load predictions, which were used in the decisions on air space closure over Central Europe. This paper describes the Falcon measurements, summarizes the data obtained and presents some early analyses and experiences. It should serve as a basis for more detailed analyses and upcoming studies.

\section{Experimental methods}

\subsection{Falcon measurement system}

The Falcon 20E, a twin-engine jet aircraft, see Fig. 1, was built by Dassault in 1975. The turbofan jet engines of type Honeywell TFE 731-5BR-2C $(2 \times 21 \mathrm{kN}$ thrust $)$ were renewed in 1995 . The aircraft ceiling is $12.8 \mathrm{~km}$, cruise speed near $200 \mathrm{~m} \mathrm{~s}^{-1}$, endurance about $4.5 \mathrm{~h}$, with about $3100 \mathrm{~km}$ range. The aircraft has been used in recent years for many atmospheric research projects (Schlager et al., 1997; Schumann et al., 2002; Minikin et al., 2003; Gayet et al., 2006; Reitebuch et al., 2009; Weinzierl et al., 2009; Voigt et al., 2010). In particular, the Falcon has been measuring in desert dust regions at dust loads of up to $5 \mathrm{mg} \mathrm{m}^{-3}$, without notable damage to the engines (Weinzierl et al., 2009).

For the VA flights, the aircraft had been instrumented within a few days after the volcanic eruption onset with 
Table 1. Falcon instrumentation for the DLR volcanic ash missions in April/May 2010.

\begin{tabular}{|c|c|}
\hline Instrumentation & Measured quantity \\
\hline \multicolumn{2}{|c|}{ Remote sensing instrument } \\
\hline 2- $\mu \mathrm{m}$ Wind-lidar & $\begin{array}{l}\text { Vertical profile of attenuated aerosol backscatter and wind } \\
\text { vector below the aircraft }\end{array}$ \\
\hline \multicolumn{2}{|c|}{ Aerosol in-situ instruments sampling sub- $2.5 \mu \mathrm{m}$ particles behind the aerosol inlet } \\
\hline $\begin{array}{l}\text { Multi-channel condensation particle counter (CPC; } 3 \text { unheated, } \\
2 \text { heated channels) }\end{array}$ & $\begin{array}{l}\text { Integral number of ultrafine particles }(D>4 \mathrm{~nm}) \text { and } \\
\text { non-volatile fraction }\end{array}$ \\
\hline 2-channel Optical Particle Counter (Grimm SKY-OPC 1.129) & $\begin{array}{l}\text { Total and } \\
\text { non-volatile size distribution }(D>0.25 \mu \mathrm{m})\end{array}$ \\
\hline $\begin{array}{l}\text { Three-wavelength Particle Soot Absorption Photometer } \\
\text { (3- } \lambda \text {-PSAP) }\end{array}$ & Absorption coefficient at $\lambda=467, \lambda=530$ and $\lambda=660 \mathrm{~nm}$ \\
\hline Impactor sampler & Chemical composition and shape of particles \\
\hline
\end{tabular}

Aerosol in-situ instruments at wing stations

\begin{tabular}{ll}
\hline Passive Cavity Aerosol Spectrometer Probe (PCASP-100X) & $\begin{array}{l}\text { Size distribution accumulation mode, dry state } \\
(0.16 \mu \mathrm{m}<D<3.0 \mu \mathrm{m})\end{array}$ \\
Forward Scattering Spectrometer Probe (FSSP-300) & $\begin{array}{l}\text { Size distribution coarse mode, ambient state } \\
(1 \mu \mathrm{m}<D<25 \mu \mathrm{m})\end{array}$ \\
Two-dimensional imaging cloud probe (2D-C) & $\begin{array}{l}\text { Shape and size distribution of very large particles, water } \\
\text { droplets and ice-crystals }(25 \mu \mathrm{m}<D<800 \mu \mathrm{m})\end{array}$ \\
Giant Particle Collector $(\mathrm{GPaC})$ & Chemical composition and shape particles
\end{tabular}

Trace gas in-situ instruments

\begin{tabular}{ll}
\hline $\mathrm{SO}_{2}$ detector (fluorescence) & Sulfur dioxide mixing ratio \\
$\mathrm{O}_{3}$ detector (UV absorption) & Ozone mixing ratio \\
$\mathrm{CO}$ detector (vacuum $\mathrm{UV})$ & Carbon monoxide mixing ratio \\
\hline
\end{tabular}

Meteorological data

Falcon standard instrumentation

CR-2 dew point hygrometer
Position, temperature, pressure, humidity, wind

Dew point, humidity instruments that were available quickly from previous experiments; see Table 1. The instruments include a lidar, in-situ instruments for measuring aerosol microphysical properties, chemical species, and meteorological parameters like temperature, humidity and wind. Furthermore, aircraft navigation parameters (position, aircraft speed, etc.) were recorded. The 2D-C and the particle impactor instruments, see Table 1, were provided by the Laboratoire de Météorologie Physique, Clermont-Ferrand, and by the Technical University Darmstadt, respectively. All other instruments were provided by DLR. For possible early detection of engine damages, the pilots controlled temperature and pressure indicators for normal engine operations during flight. Satellite (Iridium) telephone connections were available and important for real-time communication of the results from the observers on board to the decision-making agencies.

\subsubsection{Lidar}

The 2- $\mu \mathrm{m}$ Doppler wind lidar (light detection and ranging) was deployed on the Falcon aircraft in a downward looking direction performing conical scans for the retrieval of vertical profiles of the horizontal wind vector and attenuated aerosol backscatter. The coherent, heterodyne-detection lidar is based on a transceiver unit from Lockheed Martin Coherent Technologies. The laser is transmitting pulses with a wavelength of $2.02 \mu \mathrm{m}$, duration of $400 \mathrm{~ns}$, energy of $1-2 \mathrm{~mJ}$, and a repetition rate of $500 \mathrm{~Hz}$ (Köpp et al., 2004). Measurements are obtained from an altitude of $400 \mathrm{~m}$ below the aircraft to the ground with a vertical resolution of $100 \mathrm{~m}$. The wind vector is derived by a velocity-azimuth-display technique from 20 line-of-sight (LOS) directions during one conical scan with a horizontal resolution of 4-6 km depending on aircraft ground speed (Reitebuch et al., 2001). Accuracies of 
better than $1 \mathrm{~m} \mathrm{~s}^{-1}$ can be achieved for the horizontal wind speed (Weissmann et al., 2005a, b). The backscatter signal is obtained after averaging a number of 500 laser pulse-returns during $1 \mathrm{~s}$ for each LOS and applying a correction for range $R$ with a factor of $R^{2}$. Thus, the signal profiles are obtained with a horizontal resolution of $150-200 \mathrm{~m}$ for typical aircraft speeds. The range-corrected signal depends on the vertical profile of the atmospheric backscatter and extinction coefficient, which are both depending on the particle (aerosol, cloud, ash) content of the atmosphere, their size distributions and scattering properties. The $2-\mu \mathrm{m}$ laser wavelength is higher than the typical wavelengths of up to $1.064 \mu \mathrm{m}$ for ceilometers (Flentje et al., 2010) or aerosol lidars (Ansmann et al., 2010), which were used to observe the VA plumes from the ground. Thus, the $2-\mu \mathrm{m}$ lidar observations complement those ground observations for a wavelength, which is comparable to the size of the VA particles. The heterodyne detection method is more sensitive to lower aerosol contents in the atmosphere compared to a direct-detection aerosol lidar, because the heterodyne signal is analyzed in a much lower frequency bandwidth, making it insensitive to the solar background. On the other hand, the volume backscatter and extinction coefficient cannot be derived directly from the heterodyne signal, as it is performed for aerosol lidars (Ansmann et al., 2010). Nevertheless, the real-time display of the signal-to-noise ratio was used during flights to detect the presence of VA layers, their vertical and horizontal extent and their relative signal strength compared to water or ice clouds. Thus, the lidar observations were essential as a pathfinder for subsequent in-situ observations.

In the post-flight analysis, the lower and upper boundary of the measured VA layers was determined from the rangecorrected attenuated backscatter signal of the lidar by visual inspection. Layers were identified where they were clearly separated vertically from the atmospheric aerosol boundary layer, showed signal levels lower than from water clouds but higher than typically observed in the free troposphere, and are characterized by a strong signal vertical gradient. As the VA layers showed high signal levels combined with high signal gradients within 100-200 m, the upper and lower boundaries could be clearly identified. The uncertainty in the determination of the VA layer boundaries is $\pm 150 \mathrm{~m}$ resulting from the range resolution of the lidar $( \pm 50 \mathrm{~m})$ and the applied threshold on the signal strength and gradient $( \pm 100 \mathrm{~m})$.

\subsubsection{In-situ aerosol instruments}

The in-situ aerosol instrumentation covered the whole particle size spectrum including particles in the nucleation mode (4-10 nm diameter), Aitken mode (10-160 nm), accumulation mode $(160 \mathrm{~nm}-1 \mu \mathrm{m})$, coarse mode $(1 \mu \mathrm{m}-25 \mu \mathrm{m})$ and particles in the far super-micron diameter range (up to $800 \mu \mathrm{m})$. The particle fraction above $160 \mathrm{~nm}$ was sized by a combination of optical particle counters: Optical Particle Counter Grimm SKY-OPC model 1.129 (OPC), Passive
Cavity Aerosol Spectrometer Probe (PCASP) of type PMS PCASP-100X, and Forward Scattering Spectrometer Probe (FSSP) of type PMS FSSP-300 (Weinzierl et al., 2009), see Table 1. The measurement principle of these instruments is the sizing of particles based on the detection of the amount of light scattered by single particles. The instruments convert the scattering signal into an electrical signal, which corresponds to size information and is resolved into an array of channels which is fixed in case of the three aerosol spectrometers used in this study. The instruments differ mainly in optical geometry and electronic signal processing, and, as a result, cover different particle size ranges. According to the manufacturers, the PCASP covers nominally the size range $0.12-3.5 \mu \mathrm{m}$ (15 channels), the OPC $0.25-32 \mu \mathrm{m}$ (31 channels) and the FSSP 0.3-20 $\mu \mathrm{m}$ (31 channels). During the Falcon flights discussed in this study, we found the FSSP to show false counts due to electronic noise in the lowest channels as well as unrealistically high count rates in some of its higher channels (in particular channels 24, 25, 30 and 31). Close inspection of the raw data of the instrument suggested disregarding the counts outside the channel range 12-23. This limits in particular the upper end of the size range of the FSSP instrument considerably (for instance, maximum particle diameter of $14 \mu \mathrm{m}$ for channel 23 instead of $30 \mu \mathrm{m}$ for channel 31 , referring to a case of nonabsorbing aerosol). However, we will show below that the maximum of the volume size distribution has been captured even within the reduced FSSP size range. For the PCASP the two lowest channels were disregarded due to electronic noise, raising the lower end of the PCASP size range to about $0.16 \mu \mathrm{m}$. Below this size, the total number of particles larger than $4 \mathrm{~nm}$ and larger than $10 \mathrm{~nm}$ is known from CPC measurements which were operated at different cut-off diameters (Schröder and Ström, 1997). In addition to the total size distribution, the size distribution of the non-volatile aerosol compounds was also measured. For this purpose, a second OPC and two of the CPCs were connected to a thermal denuder heating the aerosol to $250^{\circ} \mathrm{C}$. The heating temperature of the thermal denuder allows the separation of high to medium volatile organics and components of sulfuric acidlike and ammonium sulfate-like behavior from non-volatile or refractory components like crustal material in VA layers (Clarke, 1991). The size range from about 25 to $800 \mu \mathrm{m}$, depending on airspeed, was covered by the $2 \mathrm{D}-\mathrm{C}$ probe (Lawson et al., 2006; Gayet et al., 2009). The 2D-C instrument records the two-dimensional shadows of particles as they pass through a focused laser beam and provides information about particle shape and size from the analysis of the recorded shadow. Beyond particle sizing, the Falcon aerosol instrumentation was designed to provide information on the aerosol absorption coefficient at the wavelengths of 467, 530 and $660 \mathrm{~nm}$ with a $3-\lambda$ Particle Soot Absorption Photometer (PSAP) (Virkkula, 2010). These absorption data can be used to determine the complex refractive index of aerosols (Petzold et al., 2009). Three impactor-sampling devices were 
mounted inside the aircraft to collect VA particles for off-line single particle analysis (Ebert et al., 2002; Kandler et al., 2009). The PCASP, FSSP, 2D-C, and, in addition, the Giant Particle Collector $(\mathrm{GPaC})$ were mounted under the wings of the aircraft. All other instruments were operated in the cabin, sampling air from the Falcon aerosol inlet, which is sampling in forward direction close to isokinetic sampling conditions. For large particles, the sampling efficiency of this inlet falls off rigorously. The cut-off diameter, at which $50 \%$ of the particles pass the isokinetic inlet, depends on outside pressure and air speed. For a typical Falcon speed, the cut-off is near $2.5 \mu \mathrm{m}$ at ground level and decreases to about $1.5 \mu \mathrm{m}$ at $10 \mathrm{~km}$ altitude (Fiebig, 2001; Wendisch et al., 2004).

\subsubsection{Method for derivation of particle size distribution and ash mass concentration}

The mass concentration of ash particles is derived from particle number size distributions measured by the three optical laser aerosol spectrometers, PCASP, OPC, and FSSP, specified above (Table 1) for a given particle refractive index and density. In the literature, many papers discuss the refractive index of mineral dust (Balkanski et al., 2007; Petzold et al., 2009), but only a few data for volcanic ash are reported. For visible wavelengths, the real part of the refractive index varies between 1.5 and 1.6 for silicate glasses similar to volcanic ashes (Patterson, 1981) and between 1.48 and 1.57 for naturally occurring rocks (obsidian, basaltic glass and andesite) (Pollack et al., 1973). While the size distributions for small particles (measured by OPC and PCASP) are rather insensitive to variations of the imaginary part of the refractive index, this is not the case for the FSSP instrument (Weinzierl et al., 2009) because it is much more selective for forward scattering angles. With increasing particle absorption, the size distribution derived from the FSSP data in general shifts toward larger particle sizes. The imaginary part of the refractive index of volcanic ash varies widely. Values between 0.00027 and 0.0015 have been reported for naturally occurring rocks (Pollack et al., 1973). Patterson et al. (1983) investigated ash samples of the 1982 El Chichón eruption collected at three surface sites at distances between 12 and $80 \mathrm{~km}$ from the volcano. The imaginary part of the refractive index at $632 \mathrm{~nm}$ (the laser wavelength of the PCASP and FSSP) decreased from about 0.0015 for the sample collected at a distance of $12 \mathrm{~km}$ to the vent to 0.0008 for an $80 \mathrm{~km}$ distance sample. Clarke et al. (1983) obtained a value of 0.0034 at $550 \mathrm{~nm}$ for the imaginary part of the El Chichón ash. Patterson (1981) found an imaginary part of the refractive index for Fuego ash of 0.02 at $650 \mathrm{~nm}$. In this study, the refractive index value is confined from the measured composition of particles collected by the impactors (see Sect. 3.2 and 3.3). The density $\rho_{\mathrm{P}}$ of the (possibly porous) ash particles varies from 0.7 to $3.2 \mathrm{~g} \mathrm{~cm}^{-3}$ (http://volcanoes.usgs.gov/ash/ properties.html\#density). Here, the density $\rho_{\mathrm{P}}$ is estimated based on the impactor samples of 2 May 2010, see below.
In the analysis of the particle size distributions of the optical aerosol spectrometer probes, we initially use Mie calculations assuming spherical particles. The channels are grouped into larger size bins to account for ambiguities in the Mie scattering cross section as a function of particle size, to improve counting statistics in particular for high channel numbers, and to smooth the resulting size spectra. In principle, prolate ice particles cause a shift in size distribution toward lower sizes (Borrmann et al., 2000). To estimate the impact of particle non-sphericity of ash particles (Munoz et al., 2004) we assessed the FSSP response by T-matrix calculations for randomly-oriented prolate spheroids (Mishchenko and Travis, 1998), see Sect. 3.2.

The specific particle volume $V$ and projected particle cross-section area $A$, both per unit ambient volume, as needed to determine the effective diameter $D_{\text {eff }}=3 \mathrm{~V} /(2 \mathrm{~A})$ (Hansen and Travis, 1974; McFarquhar and Heymsfield, 1998), are computed by integrating over the respective size distributions assuming spherical particles. For ash particles of equal volume but spheroidal shapes and aspect ratio, e.g., 2:1, the effective diameter would be about $10 \%$ larger (Krotkov et al., 1999; Schumann et al., 2011). For the accumulation and coarse mode particles $(D>160 \mathrm{~nm})$ the integrals are taken directly from the PCASP and FSSP measurements. For the size distribution below this size range, we assumed that a single log-normal mode represents all particles in the Aitken mode. This is justified because in all VA cases measured, the contribution of particles below $10 \mathrm{~nm}$ size, i.e. from a nucleation mode, was negligible. For simplicity, we used the same scale and shape parameters for the lognormal Aitken mode and adjusted the fit only to the total number concentration of Aitken particles, which is calculated as the total condensation nuclei concentration from CPC measurement minus the total amount of accumulation mode particles from the PCASP. With a count median diameter of $80 \mathrm{~nm}$ and a geometric standard deviation of 1.5 of the lognormal fit we obtained overall the best overlap of the fitted Aitken mode with the PCASP size distributions, see Sect. 3.3.

\subsubsection{Trace gas instruments}

The trace gases ozone $\left(\mathrm{O}_{3}\right)$, carbon monoxide $(\mathrm{CO})$, and sulfur dioxide $\left(\mathrm{SO}_{2}\right)$, and water vapor $\left(\mathrm{H}_{2} \mathrm{O}\right)$ were measured with in-situ instruments. The individual instruments sampled air inside the cabin through rearward facing inlets mounted on top of the Falcon. Teflon (PFA) was used for the inlet tubes of the $\mathrm{SO}_{2}$ and $\mathrm{O}_{3}$ instruments to avoid wall losses. The inlet tubing of the $\mathrm{CO}$ instrument was stainless steel.

Sulfur dioxide was measured using pulsed fluorescence (Luke, 1997). The instrument deployed was a Thermo Electron $\mathrm{SO}_{2}$ Analyzer (Model 43C Trace Level). In the optical cell of the instrument, $\mathrm{SO}_{2}$ is electronically excited by radiation in the wavelength range $190-230 \mathrm{~nm}$ generated by a Xenon flash lamp pulsed at $10 \mathrm{~Hz}$. Excited $\mathrm{SO}_{2} *$ is partly quenched and photolyzed, and partly fluoresces at 
$320 \mathrm{~nm}$. This radiation is detected by a photomultiplier tube. The photomultiplier sampling gate is delayed by $30 \mu$ from the trigger of the flash lamp to reduce electronic noise associated with the flash. The fluorescence intensity is linearly proportional to the $\mathrm{SO}_{2}$ mixing ratio. The fluorescence technique is subject to a weak positive interference from aromatic hydrocarbons, $\mathrm{CS}_{2}$ and NO. Hydrocarbons are removed from the sample air in the instrument by diffusion through a semi-permeable membrane (hydrocarbon kicker). Rejection ratios (ratio of the concentration of interferant to $\mathrm{SO}_{2}$ required to produce an equivalent instrument signal) for $\mathrm{CS}_{2}$ and $\mathrm{NO}$ were determined in laboratory experiments to 20 (Luke, 1997) and 35 (Roiger, 2007), respectively. Interferences from $\mathrm{CS}_{2}$ and $\mathrm{NO}$ are considered to be negligible for the present measurements in view of observed $\mathrm{CS}_{2} / \mathrm{SO}_{2}$ and $\mathrm{NO} / \mathrm{SO}_{2}$ concentration ratios of about 0.01 (Cronn and Nutmagul, 1982) and 0.001 (Rose et al., 2006) in volcanic plumes. The detection limit of the $\mathrm{SO}_{2}$ monitor is $0.2 \mathrm{nmol} \mathrm{mol}^{-1}$. The precision and accuracy are $3 \%$ and $5 \%$, respectively. The response time of the instrument is $80 \mathrm{~s}\left(t_{95}\right)$.

Ozone was measured with a Thermo Environment ultraviolet (UV) photometric ozone analyzer (Model 49C). The instrument employs a mercury lamp to produce UV light at a wavelength of $254 \mathrm{~nm}$. The degree of absorption of the UV light is linearly proportional to the ozone concentration in the optical cell. The sample air drawn into the instrument is passed to two optical cells, one equipped with an ozone scrubber to serve as a reference gas. The flow to the reference and measurement cell is alternated every $4 \mathrm{~s}$ using solenoid valves. The light intensity of each cell is measured by separate detectors. A particle filter (Teflon, $5 \mu \mathrm{m}$ pore) is installed upstream of the optical cells to avoid scattering or absorption of UV light by particles. A weak interference of the UV absorption technique with $\mathrm{SO}_{2}$ (rejection ratio of 70) was considered during data reduction. The detection limit and response time of the instrument is $1 \mathrm{nmol} \mathrm{mol}^{-1}$ and $15 \mathrm{~s}$ with a $10 \mathrm{~s} \mathrm{lag}$ time. Precision and accuracy are $3 \%$ or $1 \mathrm{nmol} \mathrm{mol}^{-1}$ (whichever is larger) and 5\% respectively.

Carbon monoxide was measured using a fast-response $(<2 s)$ vacuum UV resonance fluorescence detector (Model AEROLASER AL 5001). UV light at a wavelength of $150 \mathrm{~nm}$ is mirrored by an optical filter into a fluorescence cell. The light is produced by a resonance lamp excited by a radio frequency discharge. The fluorescence is detected by a photomultiplier tube. The detection limit of the instrument is $3 \mathrm{nmol} \mathrm{mol}^{-1}$. Precision and accuracy are $3 \%$ and $5 \%$, respectively (Gerbig et al., 1999).

Water vapor was measured with two independent instruments: a Lyman- $\alpha$ absorption water vapor instrument operated by the DLR flight department and a dew point hygrometer (Voigt et al., 2010). The Lyman- $\alpha$ instrument has an accuracy of $5 \%$ for humidity mass mixing ratios above $10^{-4}$. Humidity data with $10 \mathrm{~Hz}$ time resolution are available at altitudes below 8 to $9 \mathrm{~km}$. The dew point hygrometer CR-2
(Buck Research Instruments) measures the temperature of a mirror carrying a thin dew or frost layer held in equilibrium with the ambient water vapor. The detection limit of the frost point hygrometer is better than $2 \mu \mathrm{mol} \mathrm{mol}^{-1}$ at a pressure of $200 \mathrm{hPa}$ for a time resolution of $2 \mathrm{~s}$. The uncertainty in the water vapor mixing ratio is mainly determined by the uncertainty in the temperature measurement and amounts to $\pm 8 \%$. This uncertainty does not include oscillations of the mirror temperature induced by the control circuit after steep gradients in humidity, which have to be removed from the data set. Depending on water vapor gradients, the response time of the frost point hygrometer is in the order of one minute to few seconds. The ambient air temperature was measured with an accuracy of $0.3 \mathrm{~K}$ with a PT100 sensor with a Rosemount inlet.

\subsection{Modeling methods}

For flight planning and for analysis of the plume age and source altitude and strength at time of emission at the volcano, we use the FLEXPART model (run at Norwegian Institute for Air Research (NILU) and DLR) and the HYSPLIT model (run at DLR) in backward or forward mode driven with different meteorological reanalysis data. The use of different models, different atmospheric datasets and different methodologies serves to provide a first guess of the robustness of the corresponding results.

The FLEXPART model (Stohl et al., 2005) driven with ECMWF reanalyzed data with $0.5^{\circ} \times 0.5^{\circ}$ horizontal resolution is used for age analysis from backward trajectories of virtual particles released at the points of measurements along the flight paths. The backward transport method accounts for turbulence and convection and has been validated by comparison to other methods (Seibert and Frank, 2004). For each grid cell along the flight tracks, 10000 particles are released. The particles are classified as passing over the volcano when approaching the volcano within $50 \mathrm{~km}$ distance. Some particles passed over the volcano several times so that their ages spread over several hours or even days. Besides minimum and maximum ages, we report the age occurring most frequently as best estimate.

Alternatively, the ash-plume age was computed using the National Oceanic and Atmospheric Administration (NOAA) Air Resources Laboratory (ARL) HYSPLIT model (Draxler and Hess, 1998; Draxler, 2003). The model was driven with reanalyzed atmospheric data from the Global Forecast System/Global Data Analysis System (GFS/GDAS) model. The calculations were performed using GFS data with $0.5^{\circ} \times 0.5^{\circ}$ or $1^{\circ} \times 1^{\circ}$ horizontal resolution. The physics in HYSPLIT was parameterized using the recommended standard settings. For the forward simulations, the Eyjafjalla ash emission was modeled using a vertical line source located at the volcano with varying mass flow rate and vertical extent. The top height $h_{\mathrm{t}}$ of the source was taken from the 6-h updated graphics issued by the VAAC. The bottom end of the line source 
was estimated to be $\left(h_{\mathrm{t}, \min }+h_{\mathrm{S}}\right) / 2$, were $h_{\mathrm{S}}$ is the volcano height and $h_{\mathrm{t}, \min }$ the minimum top-height reported for the 6-h period. The mass flow rate is computed from

$\dot{m}=\dot{m}_{\mathrm{ref}}\left(\frac{h_{\mathrm{t}}-h_{\mathrm{S}}}{h_{\mathrm{t}, \mathrm{ref}}-h_{\mathrm{S}}}\right)^{1 / a}$

using $a=0.25$, which is between the values 0.241 and 0.259 given in Mastin et al. (2009) and Sparks et al. (1997), respectively. The reference mass flow rate $\dot{m}_{\text {ref }}$ was adjusted such that the total ash mass ejected during the first $72 \mathrm{~h}$ of the volcano eruption equals the total airborne tephra mass, $m_{\mathrm{t}}$ times the fraction of fine-grained ash below $63 \mu \mathrm{m}, m_{63}$ (grain size $\Phi=4)$. For $m_{\mathrm{t}}$ an average value of $5 \times 10^{5} \mathrm{~kg} \mathrm{~s}^{-1}$ during the first three days was used according to the preliminary estimates published by the IES. A lower bound of the fine ash fraction $m_{63}$ was estimated to be $\geq 3 \%$ from an ash sample taken $2 \mathrm{~km}$ west of the active vent on 28 April. The true fineash mass fraction in the eruption column is probably larger if we consider that the largest particles fall out fastest and hence the ground samples may underestimate the finer particle's frequency. The total "fine" ash mass was distributed equally on six representative ash particle size classes with diameters of 2, 6, 15, 25, 40 and $60 \mu \mathrm{m}$, which are handled in HYSPLIT as different pollutant species in order to account for the different sedimentation velocity of the particles. Figure 2 shows the time-series of the source characteristics as used in this study. For a given point of measurements, an ensemble of backward trajectories was computed, to obtain a first estimate of the plume age and source altitude at the time of eruption. The results were checked and corrected based on forward trajectories. The source strength was then taken from the lower panel of Fig. 2.

\subsection{Volcano plume identification from Meteosat SEVIRI data}

In order to monitor the VA plume, we utilize the Spinning Enhanced Visible and Infrared Imager (SEVIRI) "dust" image, which is a standard product used for visualization. This dust image is a red-green-blue (RGB) composite based on the brightness temperature differences between the $12 \mu \mathrm{m}$ and $10.8 \mu \mathrm{m}$ channel in red, the $10.8 \mu \mathrm{m}$ and the $8.7 \mu \mathrm{m}$ channel in green and the brightness temperature of the $10.8 \mu \mathrm{m}$ channel in blue. This imagery allows identification and tracking of the ash cloud 24-h a day and indicates regions where the ash might be obscured by ice on the volcanic ash particles or by overlying clouds. The 15-min frequency of these images allows a very good judgment of the position (but not of altitude and density) of the ash cloud if interpreted correctly. However, such an interpretation is not possible from single images without further information, since the image sometimes exhibits weak contrast between ash and water clouds (see Sect. 3.4, Fig. 14 below). Therefore, we have developed a variant of this method for ash.
It is well known that transparent ash clouds can be detected by evaluation of the brightness temperature (BT) difference of channels at $12 \mu \mathrm{m}$ and $10 \mu \mathrm{m}$ due to the so-called reverse absorption effect (Prata and Grant, 2001; Prata, 2009). Usually, BT $(10 \mu \mathrm{m})-\mathrm{BT}(12 \mu \mathrm{m})<0$ for ash particles and $>0$ for clouds, but atmospheric humidity, surface properties and the satellite viewing angle modify this threshold. For a refined ash product, the threshold was tuned to $-1 \mathrm{~K}$ by visual inspection to provide a fair balance between a low false alarm rate and high detection efficiency. In a further step, the data was low-pass filtered in order to reduce the pixel noise inherent in the temperature difference data. As background we have chosen the BT $(10.8 \mu \mathrm{m})$ grayscale image for better assessment of cloudiness in the meteorological situation. It has to be kept in mind, that the intensity of the ash product is not linearly related to ash concentration.

\subsection{Flight planning}

Flight planning at DLR was based on numerical weather forecasts, trajectory-based particle-dispersion models, satellite observations and ground based lidar observations from many sources. The Falcon was operated as a "state aircraft" allowing for operations in otherwise closed air space. If necessary, the Falcon pilots were able to change the flight plan in-flight in direct contact with air traffic control.

In order to estimate the current and future spatial and temporal distribution of VA layers, the flight planning team relied on satellite products from Meteosat SEVIRI. In addition, model predictions were used from various sources, including the VAAC NAME model (http://www.metoffice.gov. uk/aviation/vaac/vaacuk_vag.html), the Lagrangian particle dispersion model FLEXPART (Stohl et al., 2005) of NILU (http://transport.nilu.no/browser/fpi), and calculations with the same model at DLR. Other VA forecasts like those from the EURAD model of the Rheinisches Institut für Umweltforschung, University of Cologne (http://db.eurad.uni-koeln. de/), from the COSMO-ART model of the Deutscher Wetterdienst (DWD, German Weather Service) and FLEXPART results from the Austrian Center for Meteorology and Geodynamics (ZAMG) in Vienna (http://www.zamg.ac.at/) were also available for some cases. Especially during the first days, the ash-dispersion model predictions suffered from incomplete knowledge about the VA source. Hence, the model results were mainly interpreted qualitatively to identify regions with high or low ash concentration.

A critical part of the flight planning process was the forecast of the expected (water) cloud cover to decide on whether the predicted ash plumes were embedded in clouds. Measurements in VA plumes inside clouds had to be avoided, as lidar signals are strongly attenuated in water clouds and the optical particle counters cannot easily distinguish between ash particles and water droplets. For long distance flights, airports had to be selected for refueling which were forecast to be free of VA impact. For these purposes, both 

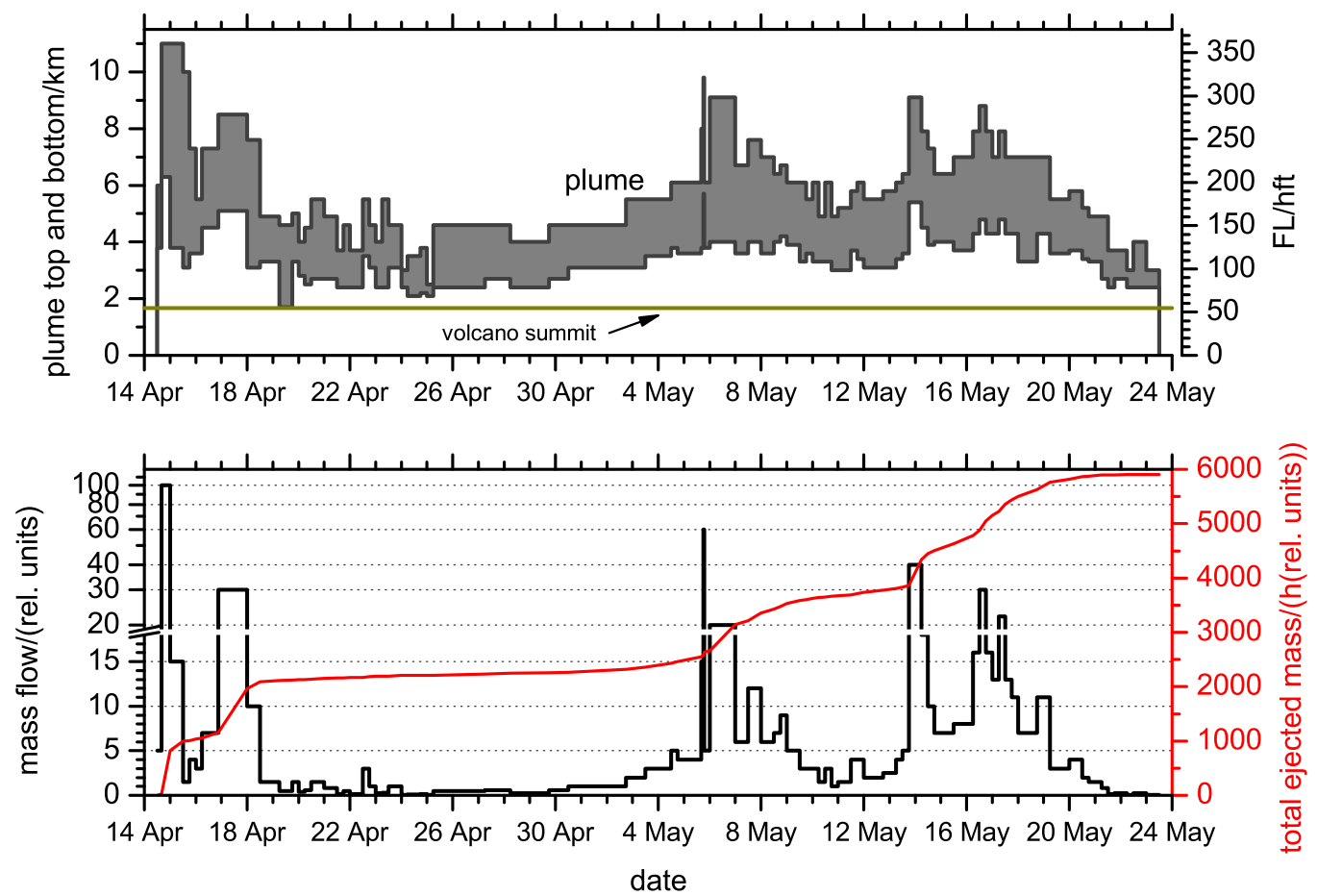

Fig. 2. Ash source characteristics used in the model. The upper panel depicts the ejection height (upper and lower bound, shaded area; $\mathrm{FL}=$ flight level in hectofeet). The lower panel shows the mass flow rate and the cumulative mass (red line) in relative (rel.) units. The unit mass flow rate corresponds to a plume top at $4.6 \mathrm{~km}$ (FL 150).

VA prediction and weather prediction data were inspected simultaneously. Weather prediction was based on deterministic meteorological forecasts from the European Centre for Medium Range Weather Forecasts (ECMWF) and on COSMO-EU and COSMO-DE forecasts of DWD. For forecasting, we strongly built on experience gained in previous campaigns. For instance, refined versions of software used during a recent campaign (Voigt et al., 2010) were employed.

When possible, the flight path of the Falcon was directed over several ground-based lidars: Munich-Maisach $\left(48.21^{\circ} \mathrm{N}, 11.26^{\circ} \mathrm{E}\right.$, operated by the Meteorological Institute of the Ludwig-Maximilians University, MIM-LMU), Leipzig $\left(51.35^{\circ} \mathrm{N}, 12.44^{\circ} \mathrm{E}\right.$; Leibniz Institute for Tropospheric Research, IfT), Cabauw and Bilthoven, Netherlands $\left(52^{\circ} \mathrm{N}, 5^{\circ} \mathrm{E}\right.$, Royal Netherlands Meteorological Institute, KNMI, and National Institute for Public Health and the Environment, RIVM), and Stuttgart $\left(48.71^{\circ} \mathrm{N}, 9.21^{\circ} \mathrm{E}\right.$, Institute of Physics and Meteorology of the University Hohenheim).

After landing and cooling of the engines (minimum $2 \mathrm{~h}$ duration), the Falcon engines were inspected for ash deposits or damage visually and by using boroscopy (endoscopy with a $1.5 \mathrm{~m}$ flexible video probe of $5 \mathrm{~mm}$ diameter). Moreover, samples of engine oil were analyzed in standard laboratories for sulfur content. On 20 April, several of the fuel injection nozzles in the combustion chamber of the Falcon engines showed corrosion damage slightly exceeding standard tolerance, because of erosion since last replacement in July 2003.
Inspection showed that the nozzle damages were not caused by the VA. The engines were repaired within 3 days.

\section{Results}

\subsection{Overview}

In this section, we describe the observation results for eight missions, partly comprising several flights. Table 2 lists information on the 17 flights performed by the DLR Falcon research aircraft to survey and sample the emissions of the Eyjafjalla volcano on Iceland. The table includes takeoff/landing times and a brief summary of the mission objective. A compilation of the flight tracks is shown in Fig. 3. Data from the instruments listed in Table 1 are available for all flights with following exceptions: Impactor sampling and $\mathrm{SO}_{2}$ detector were not flown on the first flight. The $\mathrm{GPaC}$ instrument sampled large particles successfully only on 2 May 2010. The dew point hygrometer was only flown on 8 flights between 22 April and 3 May 2010. The 2D-C probe was added for all flights from 29 April onward.

From all flights, 34 flight legs were identified, when the Falcon was clearly inside a VA plume. Table 3 lists 12 representative examples. These legs were selected based on increases in the particle concentration of coarse mode particles and $\mathrm{SO}_{2}$ mixing ratio significantly above background. The 
Table 2. List of Falcon flights during the DLR volcanic ash missions in April/May 2010.

\begin{tabular}{lccl}
\hline Date & $\begin{array}{c}\text { Take-off } \\
\text { time (UTC) }\end{array}$ & $\begin{array}{c}\text { Landing } \\
\text { time (UTC) }\end{array}$ & $\begin{array}{l}\text { Mission } \\
\text { objective }\end{array}$ \\
\hline 19 Apr & $14: 12: 02$ & $17: 54: 50$ & Aged ash plume over Germany and the Netherlands (air space in Europe largely closed) \\
$22 \mathrm{Apr}$ & $14: 14: 14$ & $15: 35: 09$ & Lidar survey over Germany \\
$22 \mathrm{Apr}$ & $17: 12: 55$ & $20: 29: 30$ & Aged ash plume south of Norway (embedded in clouds) \\
$23 \mathrm{Apr}$ & $11: 45: 56$ & $14: 57: 46$ & Aged ash plume over Germany, Poland and Baltic Sea \\
$29 \mathrm{Apr}$ & $12: 00: 10$ & $14: 09: 06$ & Ferry flight to Edinburgh \\
29 Apr & $15: 39: 59$ & $18: 28: 50$ & Flight to Iceland with lidar survey of ash plume and in-situ profiling at Keflavik airport \\
1 May & $10: 50: 29$ & $14: 05: 03$ & Lidar survey of fresh ash plume near volcano and in-situ profiling at Keflavik airport \\
2 May & $12: 58: 36$ & $16: 17: 57$ & Flight from Keflavik to Stornoway with in-situ measurement in the top part of the fresh plume \\
& & & over the North Atlantic \\
3 May & $11: 04: 40$ & $13: 31: 27$ & Ferry flight to Oberpfaffenhofen \\
9 May & $14: 26: 52$ & $18: 01: 24$ & Aged ash plume over Germany (Munich and Stuttgart airports and air space closed for 6 h) \\
13 May & $10: 06: 25$ & $11: 20: 04$ & Ferry flight to Niederrhein (Germany) \\
13 May & $12: 44: 26$ & $15: 49: 47$ & Aged ash plume in the southwest North Sea \\
16 May & $9: 11: 17$ & $11: 07: 31$ & Ferry flight to Newquay (UK) \\
16 May & $12: 34: 50$ & $16: 01: 16$ & Aged ash plume over Irish Sea and northern England (UK air space partly closed) \\
17 May & $10: 38: 47$ & $13: 29: 50$ & Aged ash plumes over Germany, the Netherlands and the North Sea \\
17 May & $14: 36: 54$ & $17: 57: 00$ & Aged dense ash plume over North Sea, extensive in-situ measurement \\
18 May & $07: 25: 32$ & $10: 34: 56$ & Aged ash plume survey over Germany and North Sea (German air space closure was under \\
& & & consideration) \\
\hline
\end{tabular}

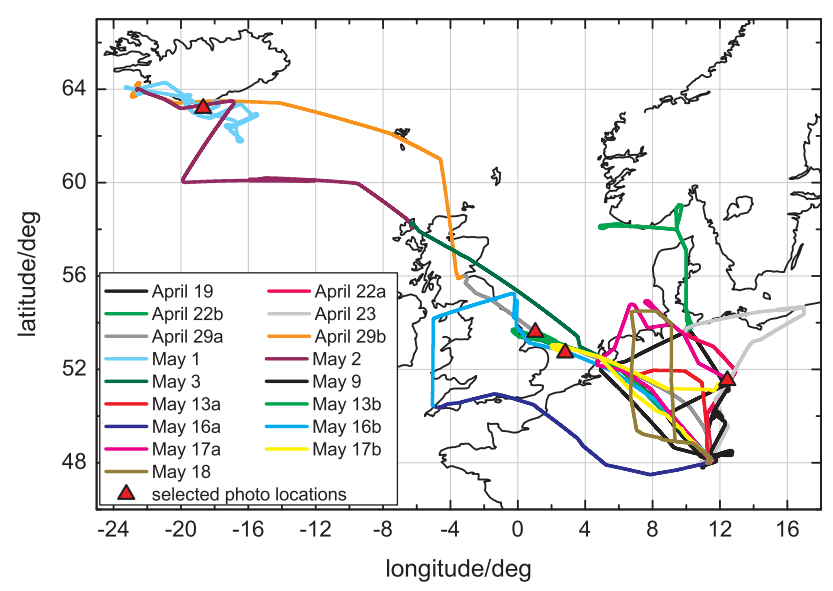

Fig. 3. Flight routes of DLR Falcon during the volcanic ash mission in April/May 2010. The photos shown in Fig. 10 were taken at the positions identified by triangles.

lidar signal was used to check whether a homogeneous ash layer was detectable. Moreover, the legs were checked for consistency of the computed backward trajectories with an ash source from the Eyjafjalla eruption. Most legs extend over a few minutes. The variability of aerosol number concentrations over these times is considerable and about $100 \%$ (standard deviation of the average). The results for 17 May, listed in Table 3 are the mean values over the descending and ascending legs over the North Sea within the altitude range of 3.2 to $6.3 \mathrm{~km}$. Besides leg-mean values, Table 3 also reports the maximum values of the 10 -s mean values in these legs. Though not directly comparable, the maximum values are of interest because the VAAC reported maximum values, not mean values. The Falcon altitude above sea level is derived from Global Positioning System (GPS) data. The aerosol parameters reported in Table 3 refer to ambient pressure and temperature. Moreover, the ratio of maximum and mean values characterizes the scatter of the data. For analysis of $\mathrm{CO}$ and $\mathrm{O}_{3}$ changes in the plumes, background concentrations are estimated from the data near the plumes; for $\mathrm{SO}_{2}$, a constant background of $0.2 \mathrm{nmol} \mathrm{mol}^{-1}$ is assumed for this purpose. The relative humidity RH refers to liquid water. The values listed were measured with the Lyman- $\alpha$ hygrometer. The CR-2 instrument results differ by less than $7 \%$ root-mean-square. Table 3 lists also the effective diameter $D_{\text {eff }}=3 \mathrm{~V} /(2 \mathrm{~A})$. In the VA plumes, the contribution to the total particle surface area of the Aitken mode particles in general exceeds that of the accumulation and coarse modes. Therefore, it was crucial to include the Aitken mode contribution in the calculation of the effective diameter. Based on the lidar signals, many of the VA layers show a multilayer structure with two or even more layers separated by gaps of 100-300 m thickness with significant lower signal. The boundaries given in Table 3 refer to the maximum extent in case of multi-layers. Analysis of the lidar and in-situ 
Table 3. Plume properties at selected flight legs.

\begin{tabular}{|c|c|c|c|c|c|c|c|c|c|c|c|c|c|}
\hline Leg & & 1 & 2 & 3 & 4 & 5 & 6 & 7 & 8 & 9 & 10 & 11 & 12 \\
\hline Position & Unit & Leipzig & Stuttgart & $\begin{array}{l}\text { Munich/ } \\
\text { Maisach }\end{array}$ & Skagerrak & Baltic Sea & $\begin{array}{l}\text { North } \\
\text { Atlantic }\end{array}$ & $\begin{array}{l}\text { Munich/ } \\
\text { Maisach }\end{array}$ & $\begin{array}{l}\text { SW North } \\
\text { Sea }\end{array}$ & $\begin{array}{l}\mathrm{NE} \\
\text { England }\end{array}$ & North Sea & Hamburg & Stuttgart \\
\hline Date & d.mon & 19.04 & 19.04 & 19.04 & 22.04 & 23.04 & 02.05 & 09.05 & 13.05 & 16.05 & 17.05 & 18.05 & 18.05 \\
\hline Leg start time & $\mathrm{h}: \min : \mathrm{s}$ & $15: 08: 35$ & $17: 18: 55$ & $17: 40: 15$ & $19: 10: 35$ & $12: 36: 57$ & $15: 11: 25$ & $14: 56: 15$ & $14: 11: 35$ & $14: 08: 35$ & $15: 50: 45$ & $09: 22: 35$ & $10: 13: 15$ \\
\hline Leg end time & $\mathrm{h}: \min : \mathrm{s}$ & $15: 15: 35$ & $17: 21: 25$ & $17: 43: 45$ & $19: 12: 55$ & $12: 37: 59$ & $15: 14: 35$ & $15: 00: 35$ & $14: 15: 15$ & $14: 15: 55$ & $16: 57: 35$ & 09:30:45 & $10: 16: 45$ \\
\hline Longitude & $\operatorname{deg} E$ & 12.45 & 9.63 & 11.09 & 8.57 & 16.52 & -15.17 & 12.6 & 1.45 & -0.17 & 2.92 & 9.12 & 9.97 \\
\hline Latitude & $\operatorname{deg} \mathrm{N}$ & 51.29 & 48.58 & 47.89 & 58.05 & 54.66 & 60.17 & 48.38 & 53.41 & 54.76 & 52.83 & 53.17 & 48.87 \\
\hline Height & $\mathrm{km}$ & 4.2. \pm 0.2 & $3.8 . \pm 0.1$ & $4.0 . \pm 0.1$ & $2.6 . \pm 0.0$ & 2.7. \pm 0.0 & $3.5 . \pm 0.2$ & 4.1. \pm 0.2 & $5.1 . \pm 0.0$ & $6.1 . \pm 0.4$ & $5.2 . \pm 1.6$ & $3.1 . \pm 0.1$ & $5.2 . \pm 0.1$ \\
\hline Pressure & $\mathrm{hPa}$ & 598 & 634.5 & 621 & 725.4 & 724.4 & 661.5 & 609.4 & 528.6 & 459.9 & 530.7 & 697.3 & 527.9 \\
\hline Temperature & ${ }^{\circ} \mathrm{C}$ & -14.4 & -9.8 & -10.8 & -13.2 & -12.8 & -6.3 & -11.8 & -22.0 & -28.5 & -23.7 & -7.3 & -21.3 \\
\hline Wind speed & $\mathrm{ms}^{-1}$ & 15.8 & 7.4 & 6.7 & 6.4 & 15.8 & 15.4 & 9.1 & 12.9 & 10.2 & 13.9 & 7.5 & 16.2 \\
\hline Wind direction & deg & 270 & 293 & 318 & 288 & 267 & 330 & 250 & 196 & 225 & 340 & 304 & 304 \\
\hline $\mathrm{SO}_{2}$ mixing ratio & $10^{-9}$ & - & - & - & 1.8 & 0.6 & 74.9 & 3.6 & 9.7 & 14.3 & 27 & 14.3 & 4.6 \\
\hline $\mathrm{CO}$ mixing ratio & $10^{-9}$ & 129.5 & 135.7 & 138.5 & 140.5 & 138.4 & 200.9 & 130.6 & 121.8 & 116.6 & 133.9 & 125.4 & 117.2 \\
\hline $\mathrm{CO}$ background & $10^{-9}$ & 129.0 & 135.0 & 138 & 140.5 & 138.5 & 128.5 & 129.0 & 114.0 & 108.0 & 120.0 & 115.0 & 115.0 \\
\hline $\mathrm{O}_{3}$ mixing ratio & $10^{-9}$ & 55.6 & 53.6 & 57.3 & 46.6 & 55.9 & 30.1 & 54.2 & 51.9 & 114.3 & 59.5 & 85.5 & 74.4 \\
\hline $\mathrm{O}_{3}$ background & $10^{-9}$ & 55.0 & 53.5 & 57.0 & 57.0 & 53.0 & 52.0 & 59.0 & 59.0 & 130.0 & & 110.0 & 110.0 \\
\hline Rel. humidity liq. & $\%$ & 17 & 17.7 & 13.7 & 56.1 & 66.5 & 59.2 & 74.6 & 49.2 & 8.3 & 32 & 17 & 11.2 \\
\hline N10 & $\mathrm{cm}^{-3}$ & 744 & 804 & 586 & 5464 & 7466 & 6465 & 2080 & 4944 & 5423 & 4875 & 2179 & 1877 \\
\hline $\mathrm{N} 10_{\text {non-volatile }}$ & $\mathrm{cm}^{-3}$ & 187 & 196 & 227 & 200 & 351 & 3334 & 677 & 189 & 154 & 215 & 278 & 219 \\
\hline N160 & $\mathrm{cm}^{-3}$ & 46 & 44 & 50 & 39 & 57 & 422 & 282 & 78 & 45 & 175 & 202 & 75 \\
\hline $\mathrm{N} 250_{\text {non-volatile }}$ & $\mathrm{cm}^{-3}$ & 5.6 & 5.2 & 4.3 & 0.9 & 0.9 & 21.2 & 0.9 & 1.4 & 5.6 & 11.4 & 7.0 & 2.3 \\
\hline N1500 & $\mathrm{cm}^{-3}$ & 0.27 & 0.22 & 0.18 & 0.03 & 0.05 & 1.48 & 0.08 & 0.12 & 0.28 & 1.34 & 0.56 & 0.25 \\
\hline N6000 & $\mathrm{cm}^{-3}$ & 0.0093 & 0.0048 & 0.0072 & 0.0043 & 0.0090 & 0.1129 & 0.0017 & 0.0011 & 0.0022 & 0.0840 & 0.0194 & 0.0044 \\
\hline Mass conc. (M) & $\mu \mathrm{g} \mathrm{m}^{-3}$ & 25 & 16 & 17 & 16 & 19 & 219 & 11 & 12 & 21 & 186 & 54 & 20 \\
\hline Mass conc. (L-H) & $\mu \mathrm{g} \mathrm{m}^{-3}$ & $17-42$ & $13-29$ & $12-27$ & $11-21$ & $13-16^{\ddagger}$ & $121-301$ & $10-16$ & $11-20$ & $19-40$ & $105-283$ & $38-93$ & $16-38$ \\
\hline Max mass c. $(\mathrm{N})$ & $\mu \mathrm{g} \mathrm{m}^{-3}$ & 48 & 22 & 52 & 40 & 24 & 558 & 22 & 32 & 54 & 544 & 110 & 52 \\
\hline Max mass c. (L-H) & $\mu \mathrm{g} \mathrm{m}^{-3}$ & $31-107$ & $19-42$ & $26-105$ & $21-58$ & $15-27$ & $283-765$ & $16-36$ & $13-56$ & $48-112$ & $282-830$ & $66-214$ & $26-88$ \\
\hline$D_{\text {eff }}(\mathrm{M})$ & $\mu \mathrm{m}$ & 1.5 & 1.1 & 1.3 & 0.3 & 0.2 & 1.8 & 0.3 & 0.2 & 0.3 & 2.1 & 1.2 & 0.7 \\
\hline$D_{\text {eff }}(\mathrm{L}-\mathrm{H})$ & $\mu \mathrm{m}$ & $1.1-2.2$ & $0.9-1.7$ & $0.9-1.9$ & $0.2-0.4$ & $0.2-0.2$ & $1.1-2.2$ & $0.3-0.4$ & $0.2-0.4$ & $0.3-0.6$ & $1.3-2.8$ & $0.9-1.9$ & $0.6-1.3$ \\
\hline$D_{\max }(\mathrm{M})$ & $\mu \mathrm{m}$ & 9.1 & 5.9 & 6.3 & 13.5 & 7.6 & 8.9 & 5.4 & 3.3 & 3.6 & 11.3 & 9.5 & 11.6 \\
\hline$D_{\max }(\mathrm{L}-\mathrm{H})$ & $\mu \mathrm{m}$ & $4.9-8.5$ & $3.6-6.0$ & $5.0-6.3$ & $10.3-21.9$ & $5.8-16.1$ & $5.9-16.8$ & $4.2-5.4$ & $2.6-4.6$ & $2.8-4.1$ & $6.2-18.2$ & $5.1-19.9$ & $3.5-19.6$ \\
\hline Age FLEXPART & $\mathrm{h}$ & 111 & 108 & 108 & 50 & 58 & 12 & 129 & 78 & 66 & $66-82$ & 81 & 66 \\
\hline Age HYSPLIT & $\mathrm{h}$ & 105 & 104 & 105 & 49 & 40 & 7.1 & 97 & 71 & 58 & $76-88$ & 100 & 78 \\
\hline Source altitude & $\mathrm{km}$ & $4.5-5.7$ & $3.5-6$ & $4.6-5.5$ & na & $2.8-3.2$ & $2.6-2.9$ & $3-6$ & $2-7$ & $1.8-3$ & $1.8-3$ & $2.5-4.5$ & $3-8$ \\
\hline Source strength & rel. units & $5-20$ & $3-15$ & $3-15$ & $0.2-1.5$ & $0.2-3$ & $0.5-1.5$ & $2-10$ & $1-6$ & $5-20$ & $3-50$ & $3-15$ & $3-15$ \\
\hline Layer top & $\mathrm{km}$ & $5.6^{*}$ & 3.8 & 4.2 & $5.5^{* *}$ & $3.4 *$ & $3.7 *$ & 4.9 & $5.4 * * *$ & $7.0^{*}$ & $6.3^{*}$ & 3.4 & $5.7^{*}$ \\
\hline Layer bottom & $\mathrm{km}$ & $3.9^{*}$ & 3.5 & 3.9 & $0.7 * *$ & $2.1 *$ & $1.6^{*}$ & 3.5 & $2.8 * * *$ & $3.6^{*}$ & $3.2^{*}$ & 2.8 & $4.0^{*}$ \\
\hline
\end{tabular}

Explanations: Height $=$ flight altitude above sea level from Global Positioning System data, GPS. Particle number concentrations: N10=total particles $>10$ nm. N10 $n_{\text {non }}$ volile $=$ total non-volatile particles $>10 \mathrm{~nm}$. N160 $=$ accumulation mode, $>160 \mathrm{~nm}$, PCASP. N250 non - volatile $=$ non-volatile particles $>250 \mathrm{~nm}$, OPC. N1500 $=$ coarse particles, FSSP channels $11-23,>1.5 \mu \mathrm{m}$ for case M. N6000 = super super-coarse particles, FSSP channels $17-23$, $>6 \mu \mathrm{m}$ for case M. Mass conc. $=$ mass concentration average Max mass c. $=$ Maximum of 10 -s mean values of mass concentration. $D_{\text {eff }}=3 \times$ specific volume $/(2 \times$ specific cross-section area $)=$ effective diameter. $D_{\text {max }}=$ diameter of maximum coarse mode volume-size spectrum, $d V / \mathrm{d} \log D(D)$. Age $=$ plume age from backward trajectories (resolution of FLEXPART: $0.5^{\circ} \times 0.5^{\circ}, \mathrm{HYSPLIT}^{\circ} 1^{\circ} \times 1^{\circ}$ ). Altitude $=$ altitude above sea level of backward trajectory above the volcano. Source = source strength of volcano at the time when the trajectory started from the volcano (from Fig. 2 ). Layer depth $=$ geometrical depth of the ash layer as derived from the lidar observations (layer top/bottom values with *: include multiple layers; $* *$ : no clear layer identified; $* * *$ : tilted layer of depth 400-700 m). ${ }^{\ddagger}$ : For leg 5 , the mass concentration $(M)$ exceeds that for case $\mathrm{H}$; this exception occurs once among the 34 legs analyzed, and is a consequence of a local maximum in the volume size distribution and the different channel assignments for cases $\mathrm{M}$ and $\mathrm{H}$.

data for 9 May over Munich show a mass detection limit for separated VA layers with enhanced aerosol backscatter of the order of $10 \mu \mathrm{g} \mathrm{m}^{-3}$.

\subsection{Volcanic particle properties}

Well-loaded samples of VA particles suitable for single particle analysis were collected by the impactor-sampling devices inside the cabin downstream of the Falcon aerosol inlet on 2 May and 17 May, legs 6 and 10 of Table 3. These samples were taken in VA clouds of different eruption periods and different plume ages over the North Atlantic (7$12 \mathrm{~h}$ age) and over the North Sea (60-84h). GPaC samples are available for 2 May. The particles were collected on TEM (transmission electron microscopy) grids covered with formvar foil and adhesive carbon substrate for electron microscopy. In the post-flight analysis, several hundred particles were investigated in a scanning electron microscope with an attached energy dispersive X-ray (EDX) detector. This analysis yields particle size, aspect ratio, morphology, and the element chemical composition for each single particle. Based on morphology, chemical composition and beam stability, the particles are assigned to one of the following groups: silicates, quartz, oxides, chlorides, phosphates, carbonates, sulfates, soot, biological, secondary, and mixtures of these groups. The particles inside VA plumes were found to consist of a mixture of ash particles and sulfuric acid droplets or sulfate particles. Figure 4 shows typical ash particles, with maximum size of $20 \mu \mathrm{m}$. Figure 5 shows sulfuric acid droplets and aggregates. Based on TEM studies (selected area electron diffraction) of the samples of both days, most particles are crystalline, i.e. no glasses.

The particles collected on the TEM grids of the impactors operated downstream of the aerosol inlet have sizes up to about $3 \mu \mathrm{m}$ (equivalent projected area diameter). The mean 

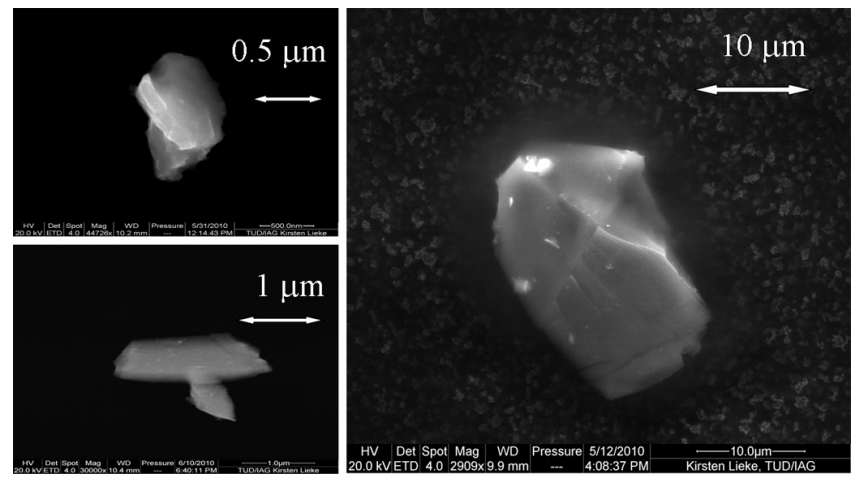

Fig. 4. Typical volcanic ash particles from the plume penetration over the North Atlantic on 2 May 2010. Left: sampled inside the fuselage, right: sampled outside. Particle sizes $0.7,2$, and $20 \mu \mathrm{m}$.
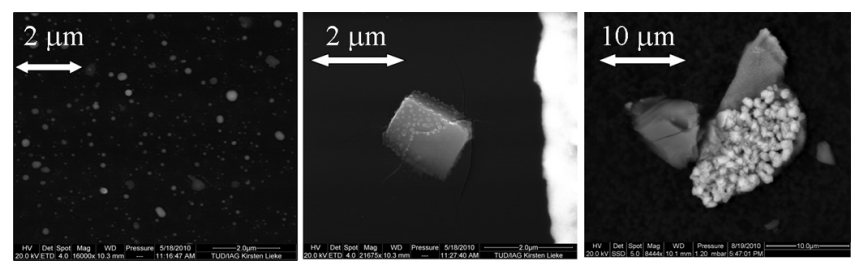

Fig. 5. Examples of ammonium sulfate particles (left), a silicate particle with droplets of ammonium sulfate (middle) and an agglomerate of large silicate particles with iron oxide (small particles; right) from the sample of 2 May.

aspect ratio is about 1.8 for particles smaller $500 \mathrm{~nm}$ and about 2 for larger particles. The relative number abundance of the different particle groups is shown for the two sampling days in Fig. 6 as function of size. Below $500 \mathrm{~nm}$, the aerosol is dominated on both days by secondary particles (ammonium sulfates/nitrates). For the larger particles, silicates and mixed particles are the most abundant groups (Fig. 4). The mixed particles mostly consist of silicates with small ammonium sulfate particles on their surface, which crystallized out of droplets (Fig. 5).

In both samples, most silicate grains (more than $90 \%$ ) are mixtures of various minerals. Based on the chemical composition, the mixtures predominantly consist of feldspars, amphiboles/pyroxenes, and pure $\mathrm{SiO}_{2}$ minerals in variable proportions. The composition of the silicates (external and within the mixtures) is different for the two sampling days (reflecting variable proportions of the different silicate minerals). For example, the $\mathrm{Si} / \mathrm{Al}$ atomic ratio ( \pm one-sigma standard deviation) decreases from $3.6 \pm 2.8$ on 2 May to $2.8 \pm 1.2$ on 17 May indicating an increasing feldspar component. The iron content is higher on 2 May with an atomic $\mathrm{Fe} / \mathrm{Si}$ ratio of 0.33 compared to $\mathrm{Fe} / \mathrm{Si}=0.08$ for 17 May. The lower iron content will lead to less absorption in the older plume. Furthermore, the sodium content is higher and the calcium concentration lower on 17 May.
The element chemical composition of the particles can be used to infer the complex index of refraction with an effective medium mixing rule (Ouimette and Flagan, 1982). Applying this mixing rule, the real and imaginary part of the refractive index is calculated as a linear combination of the refractive indices of the individual components weighted by their volume fraction. The refractive index of the individual components is taken from the literature, for details of the procedure refer to Kandler et al. (2009). As no further phase information on the specific iron minerals present in the volcanic dust is available, hematite is assumed to be the main absorbing component. The according refractive index data are taken from Sokolik and Toon (1999). The estimated uncertainties are 0.02 for the real part and possibly a factor of 3 for the imaginary part. (Balkanski et al. (2007) estimate 0.04 and $50 \%$ for the real and imaginary part based on an extensive study for mineral dust).

Table 4 shows the calculated refractive indices at $630 \mathrm{~nm}$ and $2 \mu \mathrm{m}$ (wavelengths of the FSSP and lidar lasers) for 2 May and 17 May. While there is no variation between the two ash clouds for the particles smaller than $0.5 \mu \mathrm{m}$, consisting mainly of sulfates, the data suggest larger composition changes from 2 May to 17 May for the larger particles. There could certainly be changes in the composition of the volcanic material ejected during the course of the eruption. The highest values of light absorption are generally found between 0.5 and $1 \mu \mathrm{m}$ in diameter, decreasing toward larger particles sizes in the volcanic mineral dust fraction. Particles larger than $2 \mu \mathrm{m}$ and up to $20 \mu \mathrm{m}$ collected with the $\mathrm{GPaC}$ instrument in the wing station showed imaginary refractive index values of 0.001 with low variation. While on 2 May $40 \%$ of the particles had imaginary refractive index values at $630 \mathrm{~nm}$ wavelength smaller than $0.0005,47 \%$ between 0.0005 and 0.002 and $13 \%$ of greater than 0.002 , on 17 May $64 \%$ were weakly light-absorbing $(<0.0005), 29 \%$ were between 0.0005 and 0.002 and only $7 \%$ of the particles showed higher values of greater than 0.002 .

The mean particle density $\rho_{\mathrm{P}}$ derived from the relative number abundance of particle classes and published densities for the individual minerals (Tröger, 1982) is about $2.7 \mathrm{~g} \mathrm{~cm}^{-3}$. The smaller particles with large sulfate content probably have a density similar to that of ammonium sulfate $\left(1.77 \mathrm{~g} \mathrm{~cm}^{-3}\right)$. We assumed $\rho_{\mathrm{P}}=2.6 \mathrm{~g} \mathrm{~cm}^{-3}$ to hold for all VA layers investigated in this study.

\subsection{Volcanic particle size distributions and mass concentrations}

The particle size distributions and mass concentrations are computed from the data of the optical sensors assuming three different but constant particle refractive index values, and a constant density value as given before. For the FSSP data, we consider three cases (see Table 5) which should embrace the true values as low $(\mathrm{L})$, medium $(\mathrm{M})$ and high $(\mathrm{H})$ estimates. Case $\mathrm{M}$ is considered to serve as best guess for the 

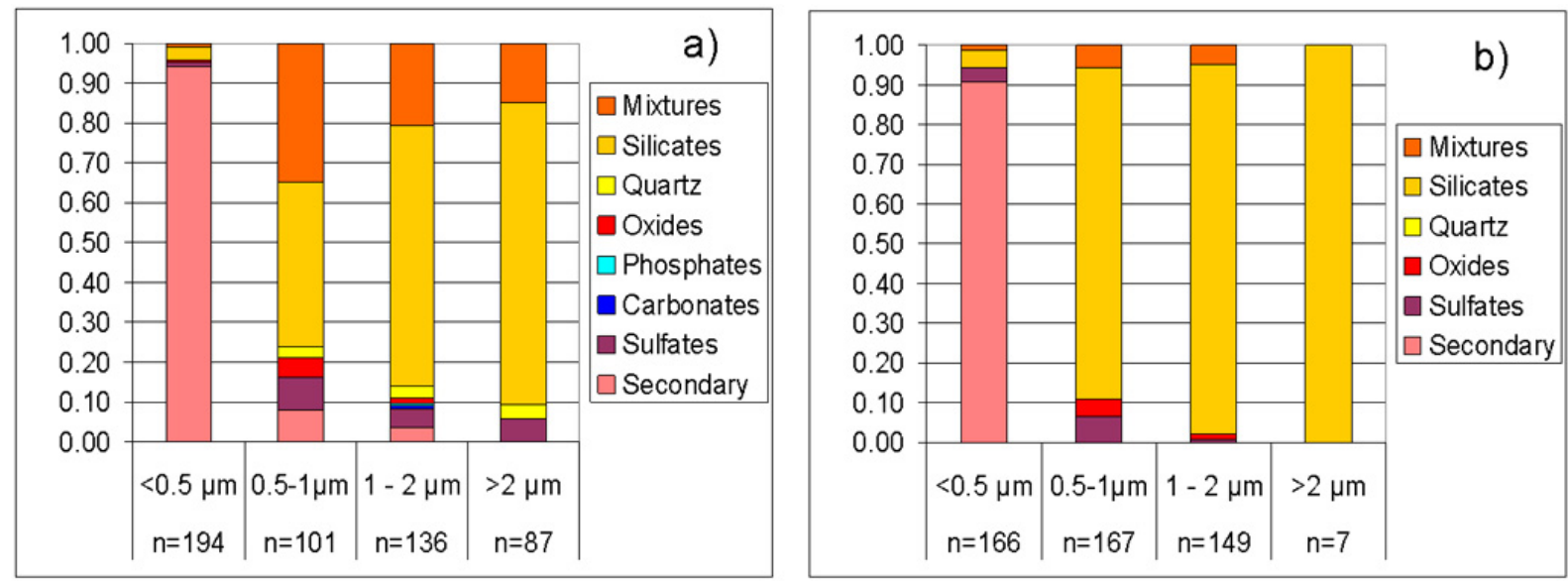

Fig. 6. Relative number abundance of particles with different chemical composition in different size bins for two sampling days ((a) 15:0115:15 UTC 2 May, (b) 16:20-16:24 UTC 17 May). Here, $n$ is the total number of particles analyzed in each size bin.

Table 4. Number of investigated particles, measured two-dimensional aspect ratio and calculated density and complex refractive index (RI) values for different particle size classes and wavelengths.

\begin{tabular}{|c|c|c|c|c|c|c|c|c|}
\hline \multirow[b]{2}{*}{$\mathrm{Size} / \mu \mathrm{m}$} & \multicolumn{4}{|c|}{2 May 2010} & \multicolumn{4}{|c|}{17 May 2010} \\
\hline & $<0.5$ & $0.5-1$ & $1-2$ & $>2$ & $<0.5$ & $0.5-1$ & $1-2$ & $>2$ \\
\hline Number & 194 & 101 & 136 & 87 & 166 & 167 & 149 & 7 \\
\hline Aspect ratio & 1.9 & 2.2 & 2 & 2.1 & 1.8 & 2.1 & 2.1 & 2 \\
\hline Density & 1.8 & 2.6 & 2.7 & 2.7 & 1.7 & 2.8 & 2.7 & 2.7 \\
\hline $\mathrm{RI}(630 \mathrm{~nm})$ & $\begin{array}{l}1.53+ \\
0.001 \mathrm{i}\end{array}$ & $\begin{array}{l}1.60+ \\
0.004 \mathrm{i}\end{array}$ & $\begin{array}{l}1.58+ \\
0.002 \mathrm{i}\end{array}$ & $\begin{array}{l}1.56+ \\
0.001 \mathrm{i}\end{array}$ & $\begin{array}{l}1.55+ \\
0.001 \mathrm{i}\end{array}$ & $\begin{array}{l}1.59+ \\
0.003 \mathrm{i}\end{array}$ & $\begin{array}{l}1.57+ \\
0.001 \mathrm{i}\end{array}$ & - \\
\hline $\mathrm{RI}(2 \mu \mathrm{m})$ & $\begin{array}{l}1.50+ \\
2 \times 10^{-6} \mathrm{i}\end{array}$ & $\begin{array}{l}1.56+ \\
40 \times 10^{-6} i\end{array}$ & $\begin{array}{l}1.55+ \\
20 \times 10^{-6} \mathrm{i}\end{array}$ & $\begin{array}{l}1.54+\mathrm{i} \\
10 \times 10^{-6} \mathrm{i}\end{array}$ & $\begin{array}{l}1.53+ \\
7 \times 10^{-6} \mathrm{i}\end{array}$ & $\begin{array}{l}1.56+ \\
20 \times 10^{-6} i\end{array}$ & $\begin{array}{l}1.55+ \\
10 \times 10^{-6} \mathrm{i}\end{array}$ & - \\
\hline
\end{tabular}

Table 5. Refractive index (RI) values used for case studies.

\begin{tabular}{llll}
\hline Case & L (“low”) & M (“median”) & H (“high") \\
\hline RI, real part & 1.59 & 1.59 & 1.59 \\
RI, imaginary part & 0 & 0.004 & 0.008 \\
\hline
\end{tabular}

observed VA properties in this study. Since larger particles appear to be less absorbing (Table 4), the true values may be also between the results for cases $L$ and $M$. The PCASP results are analyzed assuming absorbing particles, case $M$ (note, the PCASP and OPC size spectra are only weakly dependent on refractive index variations). Table 3 lists the mass concentration and size results as obtained for these three refractive index values.

Figure 7 shows the size distributions of number, surface area and volume concentrations for 19 April, 2 May and 17 May, i.e. for cases with relatively low (19 April) and high ash concentration. The results of the PCASP and OPC agree well in the overlapping size range below approximately $1.5 \mu \mathrm{m}$ particle diameter. Above this size, the FSSP data are selected to define the size distribution, while the sharp decrease of the OPC data reflects the decrease of particle penetration through the inlet with increasing particle sizes. The FSSP resolves the size ranges up to $14 \mu \mathrm{m}, 23.3 \mu \mathrm{m}$, and $27.4 \mu \mathrm{m}$, for cases $\mathrm{L}, \mathrm{M}$ and $\mathrm{H}$, respectively. The volume size distributions are of asymmetric shape with its maximum close to the upper margin of the entire size range covered by the instruments. However, for cases $\mathrm{L}$ and $\mathrm{M}$ the maximum is within the size range resolved by the FSSP. The coarse-mode volume size distributions take their maximum at a diameter $D_{\max }$ (see Table 3 ). Over all 34 cases, the $D_{\max }$ values range from $2.1-10.3 \mu \mathrm{m}, 2.2-13.5 \mu \mathrm{m}, 4.5-22 \mu \mathrm{m}$ for cases L, M, H, respectively. Extrapolating the volume size distributions with a rather broad log-normal curve fitted to the measured size distribution of the super-micron particles, shows that typically less than $10 \%$ of the total volume could have been missed in case $\mathrm{L}$ and $\mathrm{M}$. Only for case $\mathrm{H}$, larger 

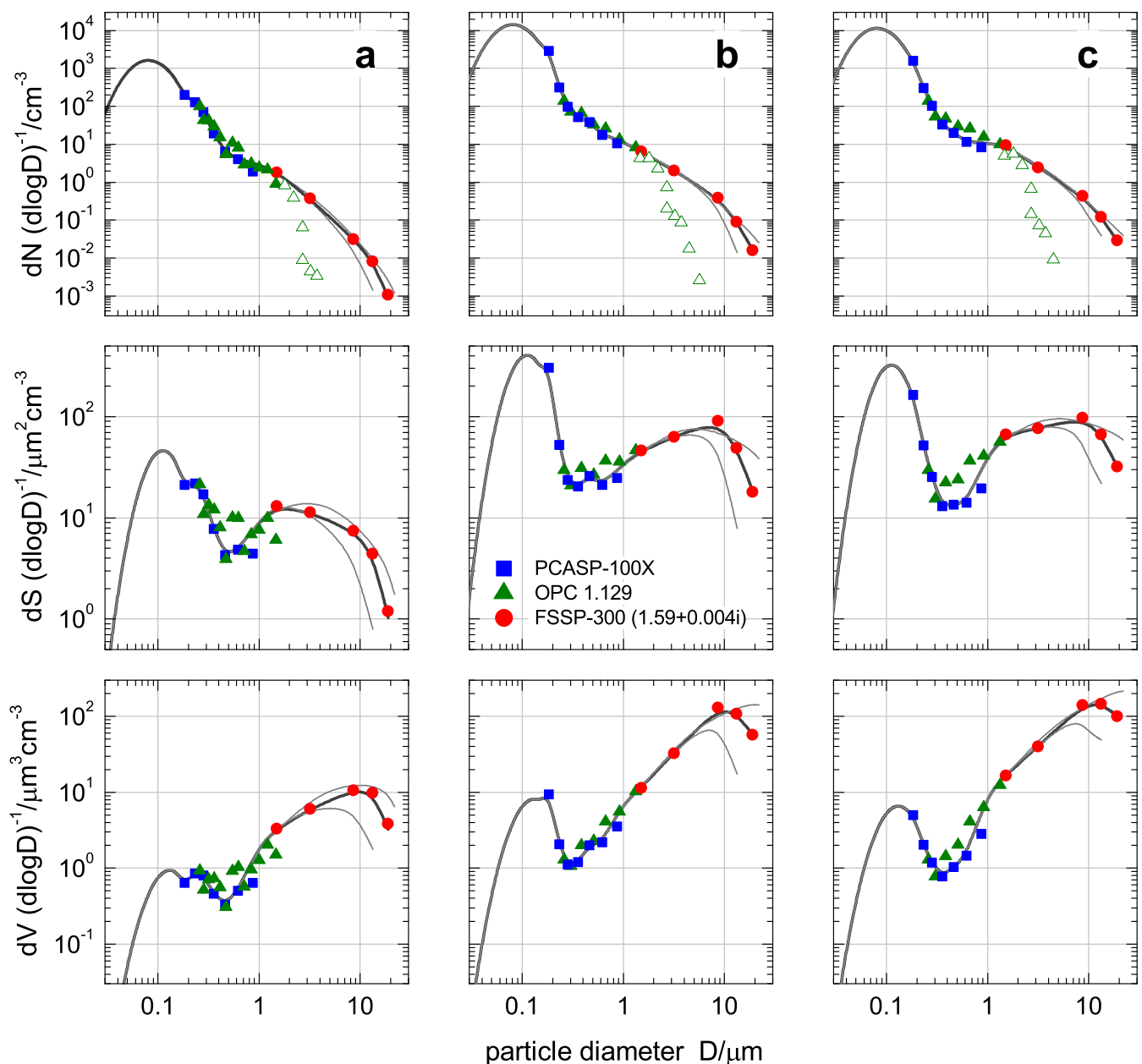

Fig. 7. Particle number $N$, surface $S$, and volume $V$ per unit size interval and unit ambient volume versus particle diameter $D$ averaged over the flight legs 1, 6, and 10 (16:11:45-16:19:55 UTC) of Table 3, i.e. (a) Leipzig, 19 April, (b) North Atlantic, 2 May, and (c) North Sea, 17 May 2010. PCASP data points are given as blue square symbols, OPC data as green triangles (open symbols represent particle sizes affected by low penetration efficiency of the inlet). Red circles represent FSSP data for case M (see Table 5). The analyzed spectra are plotted as grey curves for cases M (thick), L (thin lower), and H (thin upper curves).

volume contributions may result from particles being even larger than the size range resolved.

We note that the total particle volume concentration even in case $\mathrm{M}$ is dominated by the particles around $10 \mu \mathrm{m}$ diameter, corresponding to only a few of the size bins in the FSSP size range (mainly channels $17-21$ ). Because the volume is controlled by the third power of the particle diameter, two thirds of the total particle volume is residing above $3 \mu \mathrm{m}$, and less than $10 \%$ below $1 \mu \mathrm{m}$, for the 2 May plume, for instance. This implies that the VA volume concentration results are entirely dependent on the FSSP instrument.

The largest uncertainty of the size spectra and mass concentration results comes from the large impact of absorption of laser light by the ash particles on the measured signal. As can be seen from Table 3, an increase of the imaginary part of the refractive index of the particles from 0 to $0.004(0.008)$ increases the analyzed ash mass concentration by about a factor of up to 2.2 (3.2) in the individual cases, factor of 1.4 (2.2) on average. In view of the fact, that the imaginary part itself is uncertain to a factor of about 3 , this is the main uncertainty of this analysis. To estimate the impact of particle nonsphericity we assessed the instrument response of the FSSP by T-matrix calculations as explained above. Randomly oriented prolate spheroids with diameters larger than about 7$10 \mu \mathrm{m}$ provide, on average, the same amount of scattering as spheres with 5-10\% larger area-equivalent diameter. This would imply about $20 \%$ smaller ash mass for the same measurements. Part of this difference is accounted for by adjusting the sampling area (see below). However, the computed particle size distributions are far less sensitive to the particle shape than to the refractive index. An increase of the real part of the refractive index from 1.54, as recommended for 
mineral dust (Balkanski et al., 2007), to 1.59 (upper bound for VA according to Table 4) for non-absorbing particles, increases the derived mass concentration for selected legs (1, 6 , and 10) by less than $15 \%$. The sampling area of the FSSP is known only within an estimated uncertainty of $50 \%$. It is adjusted in this study according to the overlap with the OPC/PCASP data for the cases inside VA layers, with low relative humidity (below 40\%). In view of the differences between cases $\mathrm{M}$ relative to $\mathrm{H}$ and $\mathrm{L}$ (and the discussion results, see Sect. 4.), the overall uncertainty of mass concentrations is estimated to be about a factor of two.

\subsection{Volcanic ash observations during individual flight missions}

\subsubsection{Aged volcanic ash layer in closed air space over Germany, 19 April}

The first Falcon measurement flight for probing ash clouds from the Eyjafjalla volcano eruption was performed on 19 April 2010. Based on model predictions and trajectory analysis (Fig. 8), aged ash layers were expected in the southern and middle part of Germany, at altitudes below $6 \mathrm{~km}$ with rather inhomogeneous distribution, with ash concentrations below those predicted the days before. The VA air masses reached Germany first on 16 April (originating from the first strong volcanic eruption on 14-15 April). The maximum mass concentration estimated from the lidar observations over Leipzig and Munich reached about $1 \mathrm{mg} \mathrm{m}^{-3}$ on 16 April (Ansmann et al., 2010). The ash circulated thereafter around a high-pressure system over France before arriving in Germany a second time on 19 April. We note that the two backward trajectory models used (FLEXPART and HYSPLIT) provide age values, which differ by about $6 \%$ in this case, see Table 3. For the ash layer over Leipzig at 4-5 km altitude, the ash was about 4.3-4.6 days old at the time of measurements. For a layer at $3 \mathrm{~km}$ altitude, a slightly shorter age was calculated (3.9-4.2 days). The residence time computed by FLEXPART is the average time an air mass stays in one grid cell (a column of $0.5^{\circ} \times 0.5^{\circ} \times 12 \mathrm{~km}$ in this FLEXPART application). It is the larger the more trajectories pass through this grid cell and the smaller the wind speed. The residence time in a given grid cell gives the contribution of a unit source (in $\mathrm{kg} \mathrm{m}^{-3} \mathrm{~s}^{-1}$ ) in that grid cell to the mass concentration (in $\mathrm{kg} \mathrm{m}^{-3}$ ) at the receptor (Stohl et al., 2003). In the grid cell column near the volcano, the residence is about $200 \mathrm{~s}$. Dividing the measured ash concentration $\left(25 \mu \mathrm{g} \mathrm{m}^{-3}\right.$, see Table 3 , leg 1 , case M) by the residence time at the location of the volcano, and multiplying with the column volume at this place $\left(56 \times 25 \times 12 \mathrm{~km}^{3}\right)$, gives a column-mean emission strength of about $2000 \mathrm{~kg} \mathrm{~s}^{-1}$. This estimate is based on just one single measurement leg, and should be taken with care, therefore.

As depicted in Fig. 9, the flight path of the Falcon was directed to pass over the ground-based lidars in

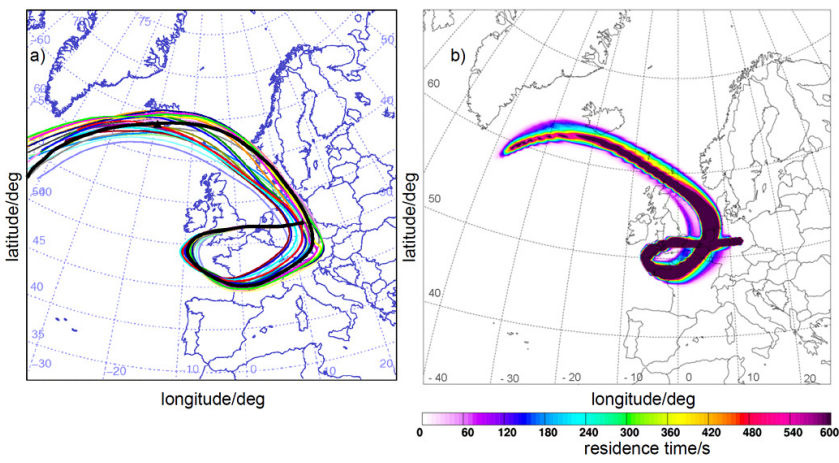

Fig. 8. Backward trajectories starting at $4.2 \mathrm{~km}$ altitude near Leipzig at 15:10 UTC 19 April (Table 3, leg 1). (a) The curves represent an ensemble of 27 backward trajectories, computed with HYSPLIT. (b) Ash mass residence times in grid cell columns of $0.5^{\circ} \times 0.5^{\circ} \times 12 \mathrm{~km}$ along the backward trajectories (back to 18:00 UTC 14 April), computed with FLEXPART.

Munich-Maisach, Leipzig, Cabauw, and Stuttgart. The Falcon flew first at $8 \mathrm{~km}$ altitude, safely above the predicted VA layers. The layers were found at the position and time as expected from the model forecasts. The airborne lidar detected several layers of strong backscatter indicating high particle concentrations at $3.7-5.8 \mathrm{~km}$ altitudes. Near Munich, two elevated layers of 500-1000 m thickness were observed. Near Leipzig, these two layers were partly combined into one layer of $1.7 \mathrm{~km}$ thickness. In general, the ash plumes were horizontally about $100-300 \mathrm{~km}$ wide. On smaller horizontal scales, the ash layers were more homogeneous than water or ice cloud layers. In the vertical, the layers were typically $0.5-2 \mathrm{~km}$ thick. The lidar backscatter in the elevated layers (above $3.7 \mathrm{~km}$ ) was lower than in the polluted boundary layer (below $3 \mathrm{~km}$ ). Between Leipzig (north of $51.9^{\circ} \mathrm{N}$ ) and Hamburg (south of $53.5^{\circ} \mathrm{N}$ ) no elevated aerosol layers were observed. Later in the flight, an ash layer was probed also at an altitude of $3.8 \mathrm{~km}$ near Stuttgart at about 17:20 UTC, see Table 3, leg 2. Under suitable viewing conditions (with the sun in the back), the ash layer was visible as a brownish layer to the observer, see photo, Fig. 10a.

Over Leipzig, the Falcon descended and probed in-situ the layers detected before by lidar, first the layer at $3.8-5.8 \mathrm{~km}$ altitude (at 15:08:35 to 15:15:35 UTC), and then the top of the boundary layer at $2.2-3.2 \mathrm{~km}$ altitude (15:23:25 to $15: 30: 55$ ). The Falcon did not descend lower. Hence, we cannot exclude additional ash layers to exist further down, see Fig. 11. In both layers the total number of particles was dominated by Aitken mode particles corresponding to fairly high condensation particle concentrations seen by the CPC. The two CPC instruments operating with 4 and $10 \mathrm{~nm}$ lower cut-off diameter showed similar concentrations indicating the absence of nucleation mode particles. Still, the Aitken particles in the elevated layer likely originate from nucleation and coagulation of sulfuric acid formed by oxidation of $\mathrm{SO}_{2}$ emitted by the volcano over the last days (Fiedler et al., 2009; Jurkat et al., 


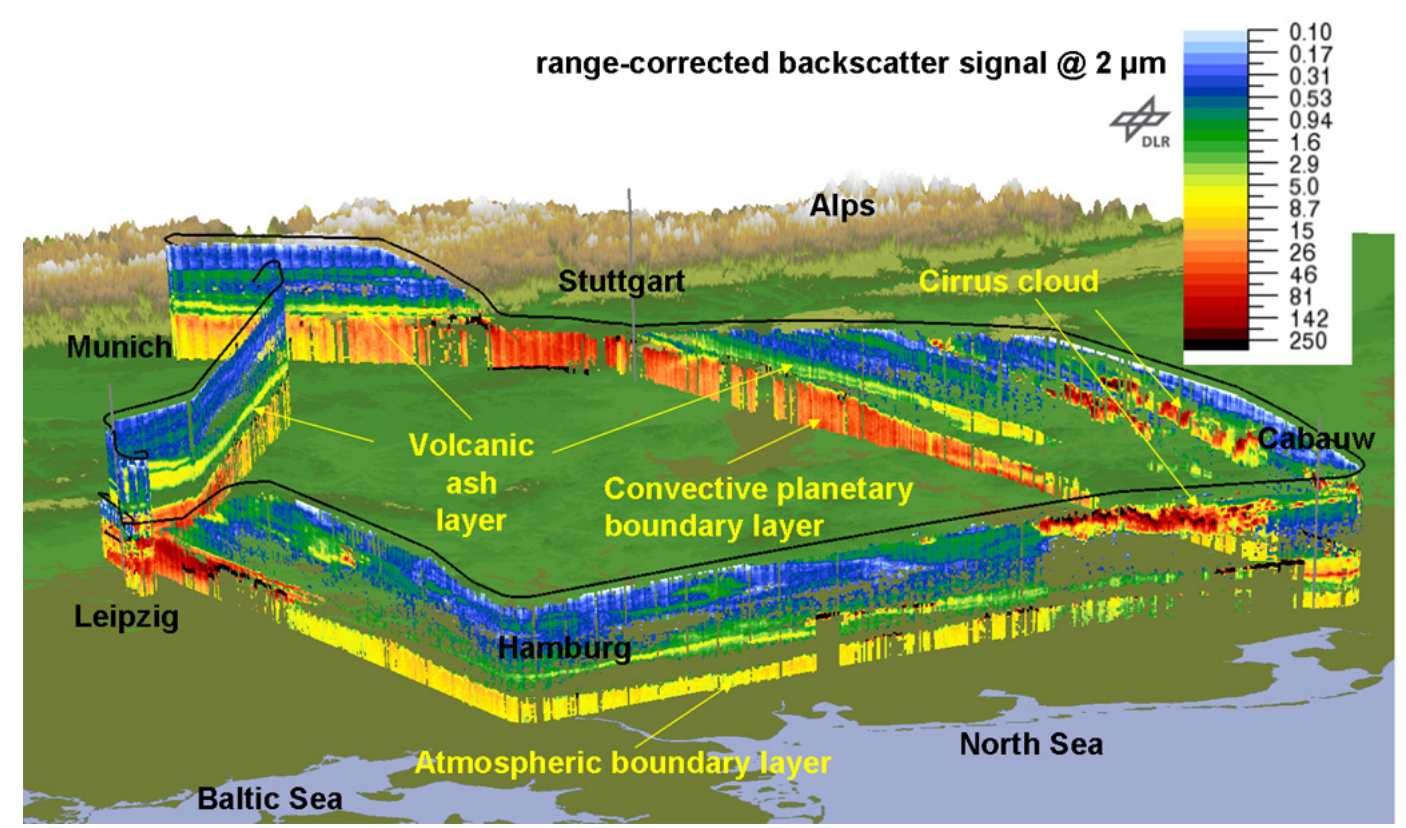

Fig. 9. Lidar cross-section (range corrected backscatter) along flight path over Germany and the Netherlands, with various aerosol layers and cities identified, 19 April 2010. Viewing direction from North to South. The flight altitude above Hamburg was $8.2 \mathrm{~km}$.
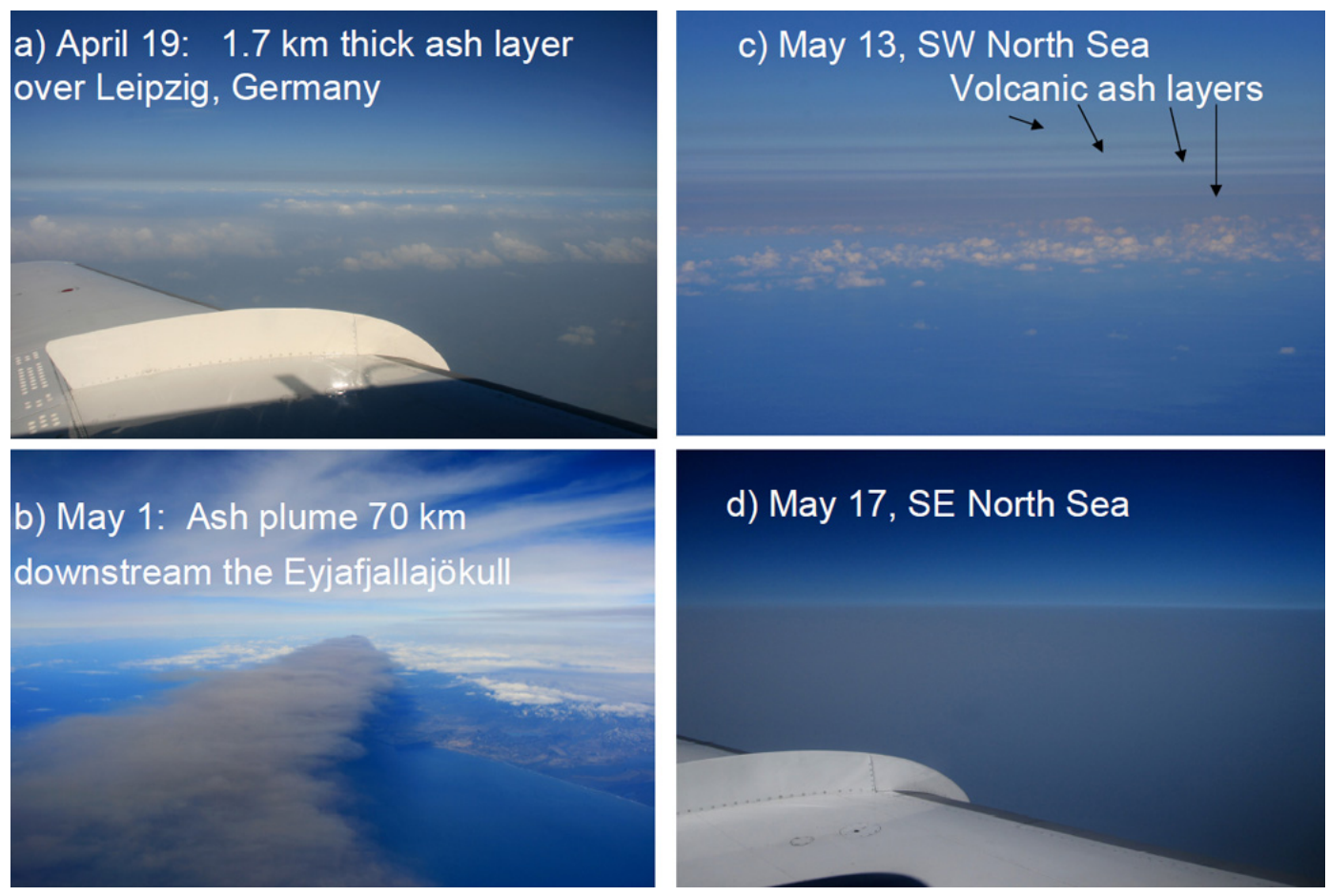

Fig. 10. Photos showing elevated volcanic ash layers (a and c), the fresh VA plume (b) and a deep VA layer (d) at various times and positions, and with various viewing directions as indicated. (a) 15:07 UTC 19 April 2010, 51.51 ${ }^{\circ} \mathrm{N}, 12.44^{\circ} \mathrm{E}, 4.25 \mathrm{~km}$, west. (b) $12: 49 \mathrm{UTC} 1 \mathrm{May}$, $63.18^{\circ} \mathrm{N}, 18.67^{\circ} \mathrm{W}, 6.7 \mathrm{~km}$, northwest. (c) 14:09 UTC 13 May, $53.59^{\circ} \mathrm{N}, 1.04^{\circ} \mathrm{E}, 5.16 \mathrm{~km}$, west. (d) $15: 54 \mathrm{UTC}^{17} \mathrm{May}, 52.70^{\circ} \mathrm{N}, 2.83^{\circ} \mathrm{E}$, $6.39 \mathrm{~km}$, southwest. The positions are identified in Fig. 3. 


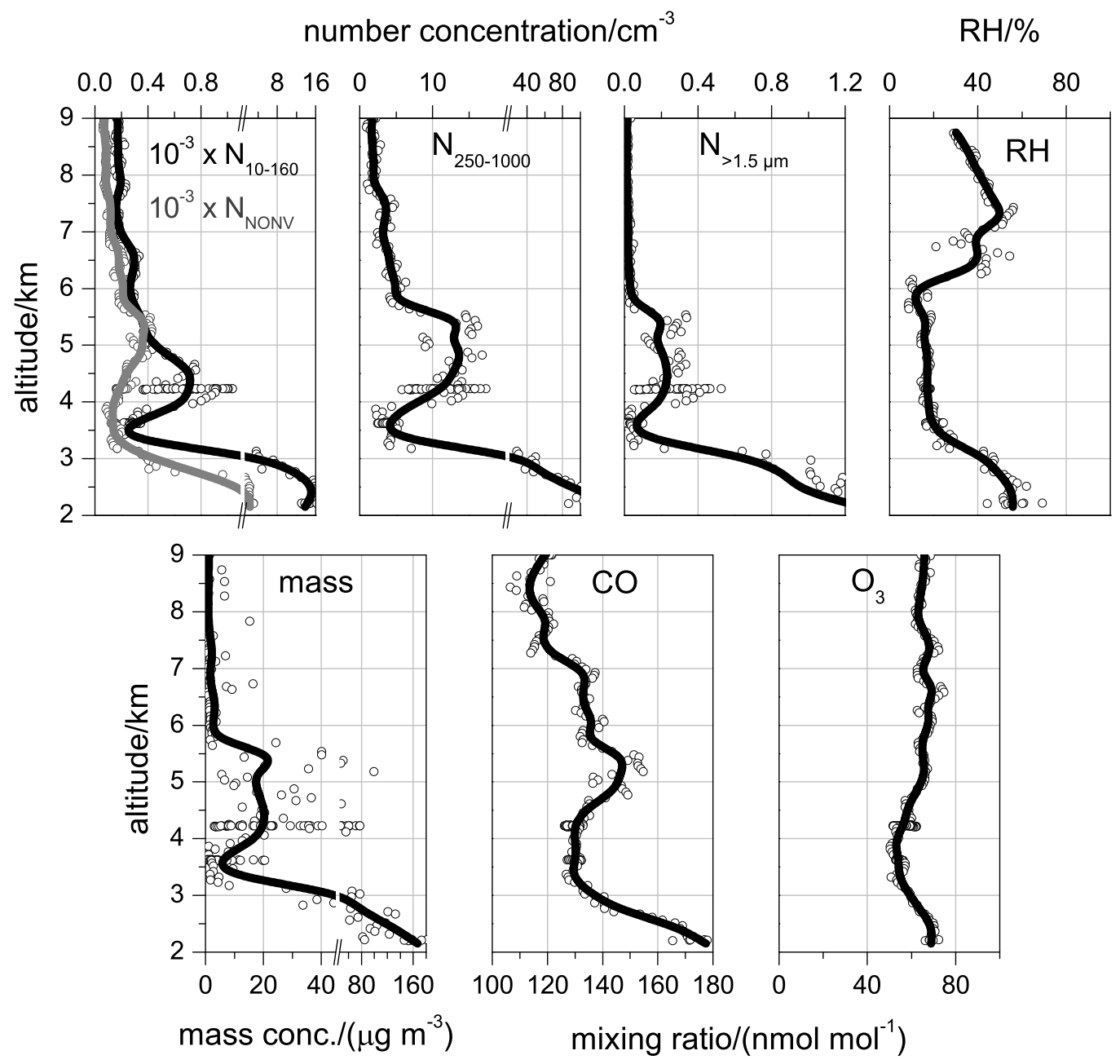

Fig. 11. Number concentrations of total aerosol particles in three size classes $(10-160 \mathrm{~nm}, 0.25-1.0 \mu \mathrm{m}$ and $>1.5 \mu \mathrm{m})$ and non-volatile particles $(>14 \mathrm{~nm}$ ), relative humidity, mass concentration (case M), and trace gas concentrations versus altitude over Leipzig, during Falcon descent, 14:51:00-15:28:00 UTC, 19 April 2010. Dots represent 10-s mean values and curves the 300-m-vertical median values.

2010). Most of the particle volume and mass is contributed by particles larger than $3 \mu \mathrm{m}$. Particles of such sizes are normally not present at these altitudes in the free troposphere. In the clean troposphere outside of VA plumes and outside clouds, the FSSP did not detect any particles above $1 \mu \mathrm{m}$. Besides enhanced aerosol concentrations, the elevated layer showed in its upper part (above $4.5 \mathrm{~km}$; see Fig. 11) high concentrations of $\mathrm{CO}$ up to $150 \mathrm{nmol} \mathrm{mol}^{-1}$, apparently above the background at this altitude of around $129 \mathrm{nmol} \mathrm{mol}^{-1}$ (Table 3), suggesting volcanic emissions. The measurements in the upper part of the boundary layer indicate urban or industrial pollution (more than $15000 \mathrm{~cm}^{3}$ condensation particles; CO mixing ratio up to $200 \mathrm{nmol} \mathrm{mol}^{-1}$ ). However, ground-based lidars show enhanced depolarization in the boundary layer over Leipzig and Munich. Therefore, parts of the large super-micron particle concentration in this layer may also result from volcanic aerosol.
The size spectrum for the first flight leg above Leipzig was shown in Fig. 7. The mean particle mass concentration derived from these spectra for the upper ash plume over Leipzig (leg 1 in Table 3), is $25(17-42) \mu \mathrm{g} \mathrm{m}^{-3}$ for case M (cases $\mathrm{L}$ and $\mathrm{H}$ ), respectively. The maximum values (of 10 -s means) reached up to $48(31-107) \mu \mathrm{g} \mathrm{m}^{-3}$. For the lower layer, the particle mass concentration is calculated to be 100 (77-163) $\mu \mathrm{g} \mathrm{m}^{-3}$; but this may include some non-volcanic aerosol. For case M, the Aitken mode controls the surface area of the VA, while particles larger $10 \mu \mathrm{m}$ form most of the aerosol volume. In the ash layer over Stuttgart, the aerosol properties were similar to those of leg 1 over Leipzig.

The concentrations of large particles measured in the VA on this day were comparable to concentrations measured typically in Saharan dust plumes (Weinzierl et al., 2009). The Falcon operated in the observed VA layers without any indication of technical problems. The windows showed no visible ash traces. Neither silver foils attached to under-wing 
stations nor boroscopy of the Falcon engines showed any damage from the VA. The fact that the Falcon was operating without problems and that the ash mass concentration was well below $0.2 \mathrm{mg} \mathrm{m}^{-3}$ contributed to the decision to reopen air space over Central Europe on 21 April.

\subsubsection{Mixed fresh and aged ash layers over Germany, Norway, and Poland, 22/23 April}

A second three-flight mission was performed on 22 and 23 April 2010, to test the validity of the VAAC predictions. The VA layer was predicted to move over the North Sea northeastward. On 22 April, during the flight from Hamburg, Germany, over Denmark toward Southern Norway and then back to Hamburg, two kinds of VA layers were detected. (1) Along a flight path in east-west direction over the Skagerrak along the south coast of Norway, VA layers were found between 2.2 and $6 \mathrm{~km}$ altitude embedded into cloudy areas, with high mixing ratios of $\mathrm{SO}_{2}$ (up to $4 \mathrm{nmol} \mathrm{mol}^{-1}$ ). The VA was rather fresh ( $36 \mathrm{~h}$ from backward trajectory analysis). One leg (leg 4 in Table 3 ) with high ash/ $\mathrm{SO}_{2}$ ratio $\left(16 \mu \mathrm{g} \mathrm{m}^{-3} / 1.8 \mathrm{nmol} \mathrm{mol}^{-1}\right.$ at $19: 10: 35-$ 19:12:55) was followed by another leg with a lower ratio $\left(15 \mu \mathrm{g} \mathrm{m}^{-3} / 2.8 \mathrm{nmol} \mathrm{mol}^{-1}\right.$ at 19:14:15-19:17:45). (2) In addition, the lidar detected an aged ash plume on the flight backward from Norway to Hamburg. This plume was about $1 \mathrm{~km}$ thick at altitudes up to $5.6 \mathrm{~km}$ in the northern part and decreased in altitude to $3.9 \mathrm{~km}$ with enhanced aerosol backscatter during the return flight toward Hamburg. The particle concentration was in general below the one measured over Germany on 19 April. The observations showed that the ash layers were found roughly at the same places and times as predicted, though details seem to differ by about $100 \mathrm{~km}$ in horizontal position.

\subsubsection{Observations near the Volcano, Iceland, 29 April-3 May}

The mission to Iceland was initiated on request of the Icelandic air-traffic control-agency (ISAVIA), because of frequent closure of the airport Keflavik, $40 \mathrm{~km}$ west of Reykjavik on Iceland. The mission included five flights between 29 April and 3 May (see Table 2).

On 29 April, the volcanic eruption was far lower than in the early eruption period. On arrival to Iceland, the plume was just visible as an enhanced cloud plume up to $3.9 \mathrm{~km}$, i.e. about $600 \mathrm{~m}$ above a low-level cloud layer with $3.3 \mathrm{~km}$ cloud top altitude. This is consistent with the reduced activity depicted in Fig. 2. During descent to Keflavik, thin layers with very low VA traces were found at altitudes between 3.6 and $4.6 \mathrm{~km}$, but nothing critical for flight safety. These results were important for local flight operations.

On 1 May, the volcano was found to have again enhanced activity and the emissions were clearly visible above the boundary layer clouds to the Falcon crew. The Falcon departed from Keflavik and performed visual/photo and lidar observations with a flight path along and perpendicular to the main plume direction, which was southeast, see Fig. 10b. The Falcon profiled first on the windward side of the plume and later again leeward but outside the plume. The ash concentration in the plume itself was obviously high and appeared far too high to allow in-situ measurements. The ash plume appeared black, with some brownish color, far darker than in the aged plumes seen over Central Europe before. This reflects the higher concentrations and higher absorption in the fresh plume. At this time, the ash was no longer in direct contact with glacier water as in the beginning of the eruption period.

At the volcano, the plume showed vigorous and intermittent convection reflecting intermittent eruptions and buoyancy. The crew felt enhanced turbulence in the air above the plume. At a distance of about 10 to $20 \mathrm{~km}$, the plume became less vigorous and the initially apparently well-mixed plume spread laterally because of directional wind shear and possibly because of horizontally variable stratification similar to a cumulonimbus anvil (Lilly, 1988; Sparks et al., 1997). At 2 to $6 \mathrm{~km}$ altitude, the in-situ Falcon profiling near the volcano showed temperatures from $-4^{\circ} \mathrm{C}$ to $-25^{\circ} \mathrm{C}$ and northwesterly winds from 10 to $30 \mathrm{~m} \mathrm{~s}^{-1}$ with weak directional shear $\left(310^{\circ}-320^{\circ}\right)$. At $220 \mathrm{~km}$ distance, the lidar shows values $10-18 \mathrm{~m} \mathrm{~s}^{-1}$ at $2-5 \mathrm{~km}$ altitude. The plume top altitude first ascended from 3.5-3.8 (at the volcano location and up to $70 \mathrm{~km}$ downstream) to $5.1 \mathrm{~km}$ in about $200 \mathrm{~km}$ distance, and then varied between 4.5 and $4.9 \mathrm{~km}$. At $220 \mathrm{~km}$ distance, $62.86^{\circ} \mathrm{N}, 15.50^{\circ} \mathrm{W}$, on 11:49 UTC 1 May 2010 , at a flight perpendicular to the plume axis, the plume had a width of about $35 \mathrm{~km}$, vertical extent from 2.8 to $4.5 \mathrm{~km}$, and a mean speed of about $14 \mathrm{~m} \mathrm{~s}^{-1}$. Hence, the volume flux was about $0.8(0.5-1.2) \mathrm{km}^{3} \mathrm{~s}^{-1}$. This result is of interest for plume dispersion modeling. From the lidar observations, it appeared that the plume was rather well mixed with sharp gradients at the lateral and the upper boundary. A top-hat function appeared more suited than a Gaussian profile to characterize the ash mass concentration inside the plume. There were also indications that the large particles were sedimenting at the lower edge of the plume. The lidar was strong enough to penetrate the total plume layer. The plume was located above the planetary boundary layer topped with stratocumulus water clouds. Above the plume, and partly at the same altitude, thin cirrus was observed. The visibility of the boundary layer cloud below the plume indicates that the optical depth of the plume was below 1.5 at the $2.02 \mu \mathrm{m}$ wavelength of the lidar. Below the sedimenting ash, the boundary layer cloud layer was breaking up.

Outside the visible plume, the atmosphere showed no measurable traces of volcanic emissions. In agreement with the VAAC predictions, Keflavik airport was free of ash on this day. The report that the volcano was more strongly active on 1 May than the days before caused an increase of the source 


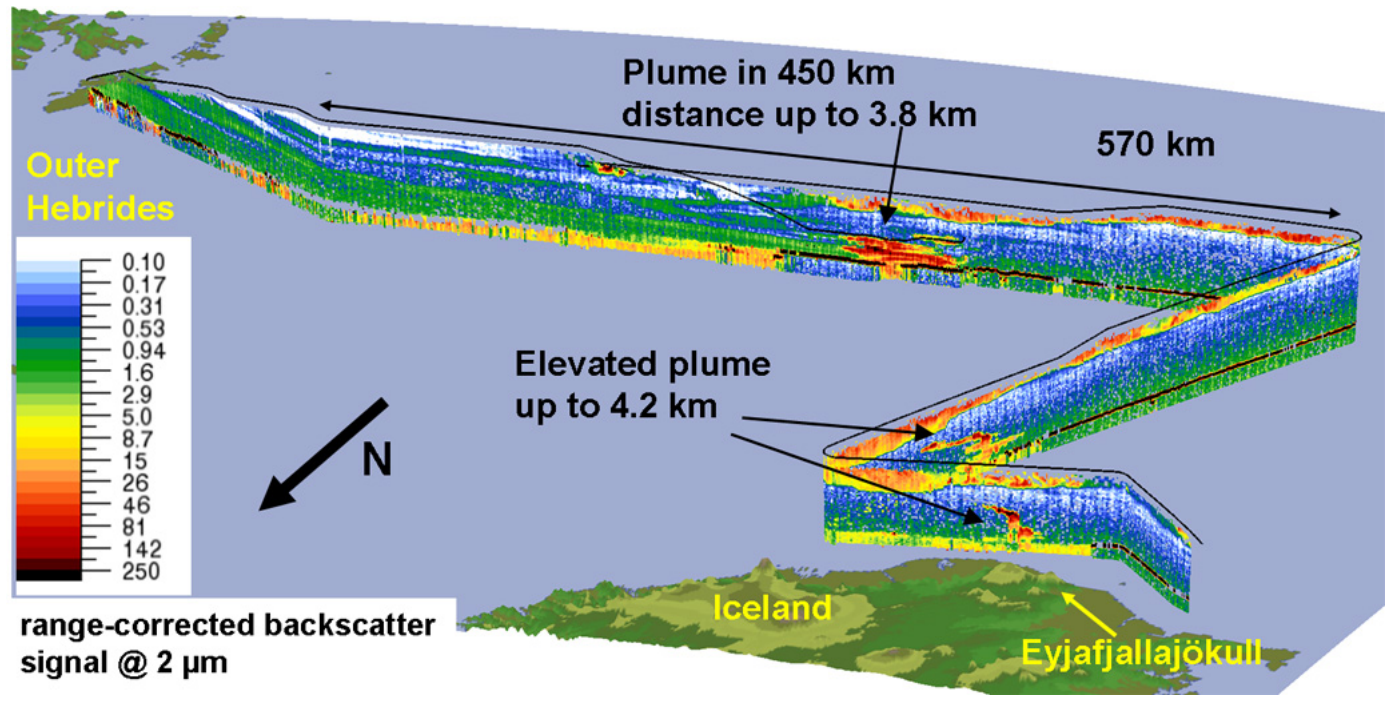

Fig. 12. Lidar cross-section showing the range corrected backscatter signal along the flight path from Iceland to Scotland on 2 May 2010. The flight altitude above the Eyjafjallajökull was $7.3 \mathrm{~km}$.

estimate in the VAAC analyses for the following days (Ian Lisk, personal communication, 2010).

On 2 May, the Falcon departed again from Keflavik and first passed over the VA plume at distances of 50 and $160 \mathrm{~km}$. At the volcano, the plume reached to about $4.2 \mathrm{~km}$ altitude, similar to the day before. From the volcano the Falcon headed south until $60^{\circ} \mathrm{N}$ latitude, where it turned east crossing the plume at a flight altitude of about $6.7 \mathrm{~km}$, and then returned first westward and then again eastward while descending slowly to perform in-situ measurements, see Fig. 12. The plume was located with the lidar at altitudes between around $1.6 \mathrm{~km}$ and $3 \mathrm{~km}$, partly above, partly within maritime boundary layer clouds (cloud top at about $1.6 \mathrm{~km}$ ). The lidar signal indicated again broken cloud cover below the plume.

The plume appeared less brown colored than on the day before, presumably because of dilution, sedimentation, and possibly washout of part of the ash particles. We note that the ash plume was below clouds during the day until shortly before the time of measurements as can be seen in pictures of the sensor MODIS on NASA's Aqua and Terra satellites. The lateral plume edges again appeared very sharp so that the crew decided not to enter the plume from the sides. Instead, the Falcon decreased speed (minimum $116 \mathrm{~m} \mathrm{~s}^{-1}$ ) and descended down to $3.4 \mathrm{~km}$ altitude, about $200-400 \mathrm{~m}$ below plume top. The plume was entered at a distance of $450 \mathrm{~km}$ from the volcano, at about 7 to $12 \mathrm{~h}$ plume age (see Table 3 ). At the bottom of the plume, the ash was about twice that old because of lower wind speed.

After entering the plume, all instruments showed strong increases of the measured values. The crew noted a darkening inside the cabin, and smelled increased $\mathrm{SO}_{2}$ concentrations. Figure 13 shows the corresponding time series of aerosol and trace gas measurements. The signature of the ash plume is obvious in all parameters shown. However, due to the larger instrument's response time, the $\mathrm{SO}_{2}$ signal is smoother and broader than the signal of the other instruments. Inside the plume, the number concentration of the total condensation particles increased by a factor of about 30 , the number concentration of coarse mode particles ( $>$ $1.5 \mu \mathrm{m}$ ) increased from zero to $3 \mathrm{~cm}^{-3}$, and the particle concentration in the accumulation mode increased up to two orders of magnitude (not shown). It is likely that the large number of particles in the Aitken mode again is a result of gasto-particle conversion from sulfuric acid formed from $\mathrm{SO}_{2}$. The CPCs with 4 and $10 \mathrm{~nm}$ cut-off agreed very well, indicating again the absence of particles below $10 \mathrm{~nm}$. Hence, particle formation must have happened earlier closer to the volcano. The Aitken mode showed maxima near the plume edges, indicating reduced formation rates in the plume center possibly because of larger coarse-mode particle surface-area. $\mathrm{SO}_{2}$ was strongly enhanced with measured maximum values of $150 \mathrm{nmol} \mathrm{mol}^{-1}$ (mean value $75 \mathrm{nmol} \mathrm{mol}^{-1}$; background is about $0.2 \mathrm{nmol} \mathrm{mol}^{-1}$ ). The actual maximum value may be larger because of the instrument's inertia. Furthermore, $\mathrm{CO}$ was enhanced ( 110 to $280 \mathrm{nmol} \mathrm{mol}^{-1}$ ), and $\mathrm{O}_{3}$ was reduced (10-60 $\mathrm{nmol} \mathrm{mol}^{-1}$ ) with a strong anti-correlation of the two signals. The reduced $\mathrm{O}_{3}$ indicates ozone loss possibly by halogen chemistry or heterogeneous chemistry (Bonasoni et al., 2004; von Glasow, 2010). The two humidity sensors give consistent results (some differences are due to different response times). In the lowest part of the flight in the plume, the relative humidity reached a minimum of only $45 \%$. The reduced relative humidity is likely caused by precipitation in the young plume. The amount of $\mathrm{SO}_{2}$ remaining at this time is far too low to explain the large amount of water vapor loss, and synoptic motions causing adiabatic warming 


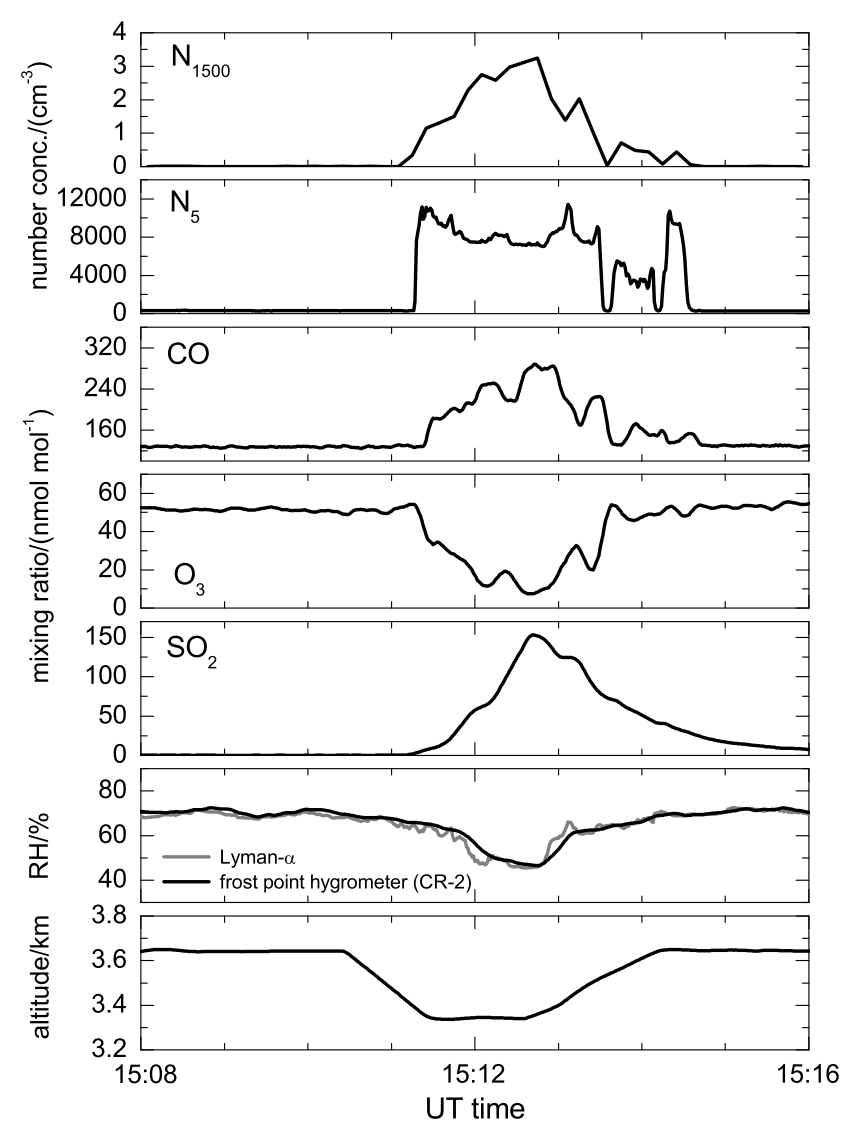

Fig. 13. Time series of aerosol number concentrations $N$ in two size ranges $(>1.5 \mu \mathrm{m}$ and $>5 \mathrm{~nm})$, trace gas mixing ratios of $\mathrm{CO}$, $\mathrm{O}_{3}$, and $\mathrm{SO}_{2}$, relative humidity $\mathrm{RH}$ from the two hygrometers, and flight altitude during the measurements over the North Atlantic versus time (h:min) on 2 May 2010.

should impact the plume as well as its ambience. During the 3-min ash plume penetration, the mean ash mass concentration was $0.2 \mathrm{mg} \mathrm{m}^{-3}$ referring to the absorption case $\mathrm{M}$. The maximum values of the 10-s mean data reached up to $0.6 \mathrm{mg} \mathrm{m}^{-3}$ for case $\mathrm{M}$, and up to $0.8 \mathrm{mg} \mathrm{m}^{-3}$ according to the high estimate, case $\mathrm{H}$. The effective diameter from the particle size distribution is $1.8(1.2-2.2) \mu \mathrm{m}$. The 2D-C probe, with a lower detection size of about $25 \mu \mathrm{m}$ at a flight speed of $120 \mathrm{~m} \mathrm{~s}^{-1}$, did show reasonable particle concentrations in cirrus clouds, but did not show a single particle count inside this and all the other VA layers penetrated by the Falcon. The GPaC impactor results (Fig. 4), show maximum particle sizes of $20 \mu \mathrm{m}$ for this case.

After about $30 \mathrm{~s}$ of measurements inside the plume, the crew decided to leave the plume. This decision was made mainly because of strongly enhanced light absorption by the ash aerosol (indicated by the 3- $\lambda$-PSAP) and increasing $\mathrm{SO}_{2}$ concentration. The Falcon slowly ascended avoiding overpowering the engines. After nearly $3 \mathrm{~min}$ the Falcon was back in clear air. It then continued towards Stornoway on the Outer Hebrides, Scotland. The next day, boroscopy and visual inspections showed no damages to the aircraft. Hence, the Falcon returned without further notable VA penetrations back to Oberpfaffenhofen on 3 May.

Based on the observations, one can again compute the plume volume flux and in addition the ash mass flux, from $F=x y v c$. Here the horizontal extent is $x=61(56-65) \mathrm{km}$, the vertical extent is $y=1.3(1.3-1.8) \mathrm{km}$, the wind speed in plume direction, assumed perpendicular to the flight path, is about $v=11(11-14) \mathrm{m} \mathrm{s}^{-1}$ on average over the plume. These values imply a plume volume flux of $0.9(0.8-1.6) \mathrm{km}^{3} \mathrm{~s}^{-1}$. This value is only slightly larger than the day before, indicating weak mixing of the plume with ambient air. According to Table 3, the mass concentration $c$ is likely $0.2(0.15-$ $0.25) \mathrm{mg} \mathrm{m}^{-3}$. Hence, the mass flux is about $175 \mathrm{~kg} \mathrm{~s}^{-1}$ (range $120-410 \mathrm{~kg} \mathrm{~s}^{-1}$ ). This value is a lower limit for the total mass flux because larger concentrations of larger particles are to be expected in the lower part of the plume. From an estimate of the lidar backscatter, a factor of 2-4 higher concentrations can be expected to occur deeper inside the plume, implying a mass flux of about $500(240-1600) \mathrm{kg} \mathrm{s}^{-1}$.

This result is smaller than the estimate of $2000 \mathrm{~kg} \mathrm{~s}^{-1} \mathrm{de}-$ duced from the FLEXPART result for the earlier eruption period (Sect. 3.4.1). It should be noted that the volcano was only moderately active during the 1-2 May period. Based on Fig. 2, a factor 50 larger eruption rate could be realistic for the maximum eruption period of 14 April. Hence, we may speculate that the mass flux in the distal plume at ages of order $10 \mathrm{~h}$ may have reached up to 25 (12-80) $\mathrm{Mg} \mathrm{s}^{-1}$ during the April/May 2010 Eyjafjalla eruption period. In order to convert this mass flux into total mass during the eruption period, we refer to Fig. 2. From that figure (see also Table 3) we take a mass flow rate of $1(0.5-1.5)$ units (as defined in Fig. 2) during 2 May. The integral over the whole period is $6000 \mathrm{~h}$ units. Hence, the total mass flux is about $6000 \mathrm{~h}$ times the instantaneous mass flux of $500 \mathrm{~kg} \mathrm{~s}^{-1}$ at 2 May. Hence, the volcano ejected about $10(2.5-50) \mathrm{Tg}$ of ash mass for the whole April/May 2010 eruption period. The measured mean $\mathrm{SO}_{2}$ mass concentration $\left(142 \mu \mathrm{g} \mathrm{m}^{-3}\right.$ for $75 \mathrm{nmol} \mathrm{mol}^{-1}$ at the measured ambient conditions, see Table 3 ) is about $0.25-$ 0.5 times the ash mass concentration this day. Hence, we estimate the $\mathrm{SO}_{2}$ mass flux rate to be of the order of $300 \mathrm{~kg} \mathrm{~s}^{-1}$ on 2 May. The $\mathrm{SO}_{2}$ emission rate may have been larger than what was estimated earlier for Mt. St. Helens and Mt. Redoubt: 10 and $140 \mathrm{~kg} \mathrm{~s}^{-1}$ (Hobbs et al., 1982, 1991). Certainly, these values are order of magnitude estimates and have to be checked when the eruption flux history has been more accurately quantified in other studies.

\subsubsection{Less ash than predicted, South Germany, 9 May}

On 9 May, an air mass with some ash content arrived in Southern Germany after 6 days of transport from the volcano southward over the North Atlantic and then over Northern Spain, Southern France, Switzerland or Western Austria, 
to Southern Germany. Meteosat dust images had shown ash signals over the North Atlantic but no indications for significant ash concentrations on its way from Spain to Germany. A flight of the Swiss MetAir-Dimona aircraft (http: //www.metair.ch/; Bruno Neininger, personal communication, 2010) did not find indications for VA at altitudes up to $4.5 \mathrm{~km}$. The VAAC products indicated a few small spots over Southern Germany with ash concentration exceeding $2 \mathrm{mg} \mathrm{m}^{-3}$. With 60 nautical miles added to account for uncertainty ranges, these predictions caused the airports of $\mathrm{Mu}$ nich and Stuttgart to close at 13:00 UTC. At the beginning of the closure, a VA layer of about $1 \mathrm{~km}$ thickness became visible at altitude of about $4 \mathrm{~km}$ in the ground based lidar observations at Munich-Maisach. At about 14:00 UTC, the Falcon took off and performed in-situ measurements profiling over Munich, then flew at larger altitudes toward Stuttgart and Leipzig, and spiraled again near Bayreuth and Munich. The ash mass concentrations measured during that flight were below $18 \mu \mathrm{g} \mathrm{m}^{-3}$. In view of these data and changed VAAC evening predictions, the airports opened again at 19:00 UTC, two hours earlier than planned in the afternoon.

\subsubsection{Multiple thin layers, south-west North Sea, 13 May}

The measurements of this day were triggered by Meteosat dust image observations of 11 May, indicating that a part of the ash cloud had left the area forecasted by the VAAC due to a mesoscale disturbance west of Ireland. On 12 May, this part of the ash cloud was observed over Northern France and southern England. The ash layer was predicted by the FLEXPART tracer model but not identified as critical for aviation $\left(>0.2 \mathrm{mg} \mathrm{m}^{-3}\right)$ by the VAAC. During the flight, which was performed on 13 May, the ash cloud was detected over the North Sea at the Northern end of the English Channel. The situation was not simple: Plumes with different microphysical and chemical properties were found. The photographs showed different layers at different altitudes, see Fig. 10c. The ash layer had a depth of 400 to $700 \mathrm{~m}$ and was inclined (2800-3300 m over the channel and 5000-5400 m over the Norwich area further north). The plume was forecasted at altitudes between 3 and $5 \mathrm{~km}$. The measured location of the plume coincided with the forecast (FLEXPART) position of the plume. The maximum ash concentration (case $\mathrm{M})$ along the flight path was less than $32 \mu \mathrm{g} \mathrm{m}^{-3}$. The maximum was observed at $5.1 \mathrm{~km}$ altitude at $53.5^{\circ} \mathrm{N}, 1.4^{\circ} \mathrm{E}$, at 14:10 UTC, with enhanced concentration of Aitken and coarse mode particles as well as an enhanced absorption coefficient. This layer also contained elevated $\mathrm{SO}_{2}$ at concentrations up to $25 \mathrm{nmol} \mathrm{mol}^{-1}$ (mean $9.7 \mathrm{nmol} \mathrm{mol}^{-1}$ ). The region with high $\mathrm{SO}_{2}$ and large particles was rather humid (50$60 \%$ ). Drier conditions prevailed further North, at 3-7 km altitude, containing smaller particle VA remainders without enhanced $\mathrm{SO}_{2}$, apparently in a different air mass.

\subsubsection{Fresh VA plume arrival over England, 16 May}

On 14 May, the VAAC predicted a strong VA layer, potentially affecting European air space. This ash layer was traced from the British Islands to the Alps in the following days with three Falcon flights on 16, 17, and 18 May (see Table 2). The VA layer arrived at the northern edge of Scotland and western coast of Ireland in the late evening of 15 May. This was first indicated by ground-based observations at Mace Head $\left(53.3^{\circ} \mathrm{N}, 9.9^{\circ} \mathrm{W}\right)$, showing a sudden increase in sulfate concentrations. The lidar at this station showed a subsiding plume (Colin O'Dowd, personal communication, 2010). The enhanced sulfate signal ended after a few hours indicating that Mace Head was touched by the southernmost edge of the ash plume only shortly. Enhanced $\mathrm{SO}_{2}$ columns were detected by an airborne differential optical absorption spectroscopy below $7 \mathrm{~km}$ altitude over Northern Ireland, $55^{\circ} \mathrm{N}$, $7^{\circ} \mathrm{W}, 09: 00$ UTC 16 May (Heue et al., 2010a). The predictions for 12:00 UTC 15 May indicated strong cloud cover over Southeast England (near London), but no high level clouds and only scattered mid level clouds over the Irish Sea.

When the Falcon reached the Irish Sea near $54.2^{\circ} \mathrm{N}$, $4.5^{\circ} \mathrm{W}$ at 13:26 UTC, the Meteosat ash product indicated that the ash plume was located further north and was moving eastward more quickly than predicted, see Fig. 14. Therefore, the Falcon was directed northeast. Immediately after changing the flight route, the lidar detected an ash plume at altitudes between $3.6 \mathrm{~km}$ and $7 \mathrm{~km}$ at $54.7^{\circ} \mathrm{N}, 3^{\circ} \mathrm{W}$, while the Falcon was flying in ash-free air masses at $7.2 \mathrm{~km}$ altitude. At $54.8^{\circ} \mathrm{N}, 0.2^{\circ} \mathrm{W}, 6 \mathrm{~km}$ altitude, at 14:10 UTC, after extensive lidar observations, the Falcon performed in-situ measurements in the upper most part of the VA plume. The lidar backscatter signal was about a factor 20 lower than on 1 and 2 May, indicating far lower ash mass concentration in the VA on this day along the Falcon flight path. The in-situ measurements showed many large particles, with a mean mass concentration of about 10 to $20 \mu \mathrm{g} \mathrm{m}^{-3}, 10$-s maximum ash concentrations up to $52 \mu \mathrm{g} \mathrm{m}^{-3}$ (Table 3 , case $\mathrm{M}$ ), a maximum $\mathrm{SO}_{2}$ concentration exceeding $30 \mathrm{nmol} \mathrm{mol}^{-1}$, and the ash plume was visible as a dark grey layer. The ash plume was clearly identified in the Meteosat ash product; see Fig. 14. As noted before the ash product is not a linear function of the vertically integrated ash concentration. The VAAC product shows the maximum ash concentration expected in the 6-km vertical layer. The observations confirmed the existence of an enhanced concentration VA plume, roughly as predicted by the VAAC, but 100 to $200 \mathrm{~km}$ further north and likely with lower concentration. The horizontal displacement between the plume predicted by the VAAC and the plume visible in the satellite image could be caused by wind field errors in the model driving the NAME model or by vertical wind shear and errors in the plume altitude assumed for these predictions. 

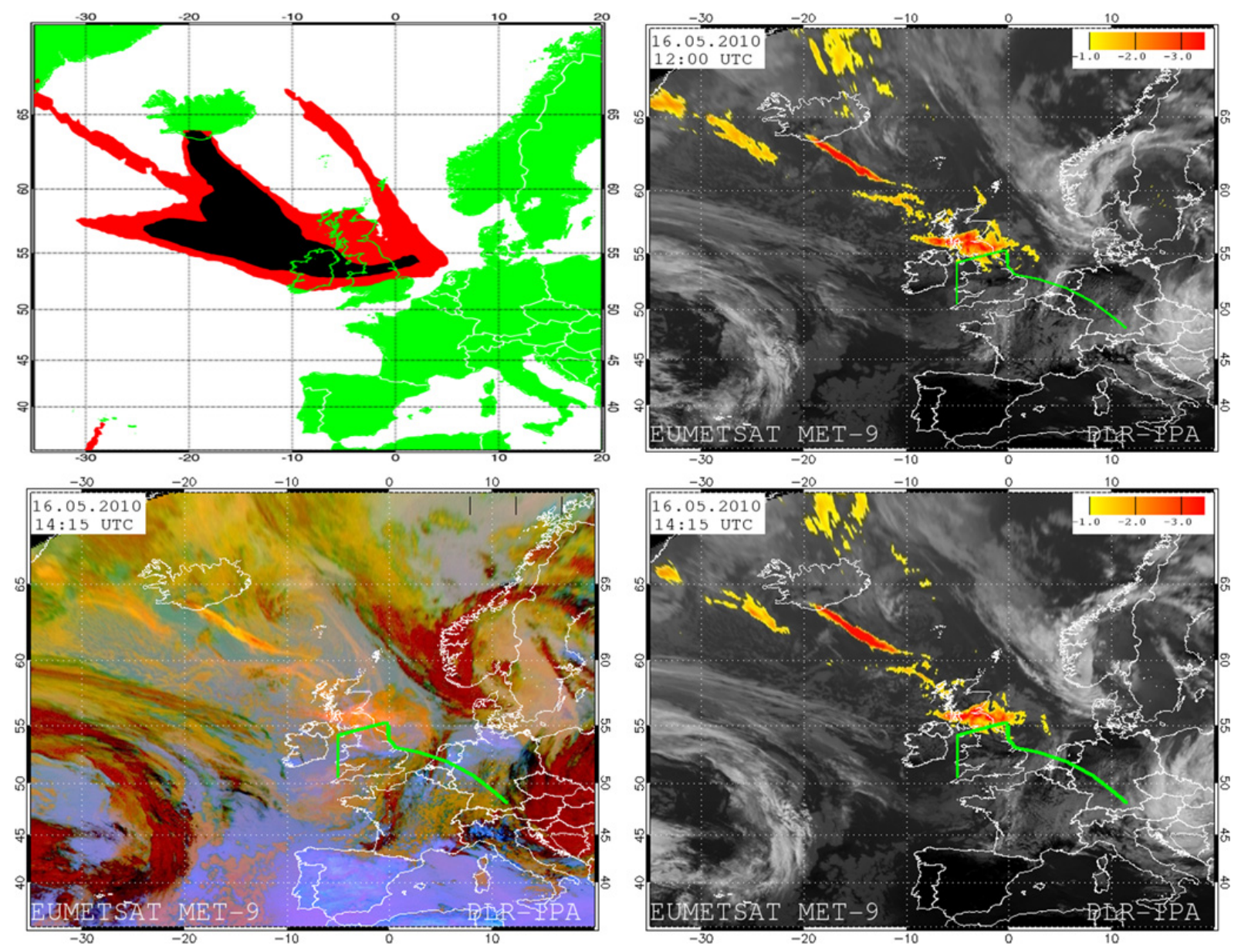

Fig. 14. Comparison of VAAC prediction for flight levels 0-6 km, issued 12:00 UTC 16 May 2010 (top left) together with various ash detection results based on Meteosat-8 SEVIRI data, in Mercator projection, including the Falcon flight path (green curve). Top: 12:00 UTC 16 May 2010; bottom: 14:15 UTC 16 May 2010. Right panels: Ash product based on brightness temperature difference $10.8 \mu \mathrm{m}-12.0 \mu \mathrm{m}$ (color bar, in Kelvin) in combination of smoothing and an upper threshold of $-1.0 \mathrm{~K}$. The grayscale background represents the $10.8 \mu \mathrm{m}$ brightness temperature. Bottom left: Dust composite, as described in text. Ash appears orange in this composite.

\subsubsection{One hour of measurements in ash over the Southern North Sea, 17 May}

The plume observed over Northern England was predicted to travel further eastward and reach Germany the next day, see Fig. 15. Therefore, the Falcon performed two measurement flights, first over the Baltic Sea and East Germany, and then over the Netherlands and the North Sea, with vertical profiles between about 6 and $1.5 \mathrm{~km}$ altitude. At the same time, VA layers were observed at $2-4 \mathrm{~km}$ altitude by a ceilometer over Essen $\left(51.4^{\circ} \mathrm{N}, 7.0^{\circ} \mathrm{E}\right)$ in Northwest Germany (Harald Flentje, personal communication, 2010). Over Leipzig, the VA layer was visible between 2.5 and $3.5 \mathrm{~km}$ altitude according to the lidar depolarization signal at 12:00 UTC. During the flight, the Meteosat ash product revealed the maximum ash signal at $54^{\circ} \mathrm{N}, 2.5^{\circ} \mathrm{E}$ at 13:00 UTC, moving southward to $53^{\circ} \mathrm{N}, 2.5^{\circ} \mathrm{E}$ at $16: 00 \mathrm{UTC}$, i.e. further west than predicted. The VA layer was detectable also in the visible range of
Meteosat SEVIRI. This information was used to direct the Falcon to fly further out to the North Sea, where an ash cloud was clearly visible, see Fig. 10d. As seen in the Meteosat ash product, Fig. 15, the measured plume arrived over the Netherlands the same day at about 18:00 UTC. The Cabauw lidar detected the ash layer at 5 to $7 \mathrm{~km}$ altitude at 19:30 UTC (Keith Wilson, personal communication, 2010).

The lidar observations revealed a distinct VA plume at 3.2 to $6.3 \mathrm{~km}$ altitude over the North Sea area, see Fig. 16. The backward trajectory analyses showed that this layer contained ashes of various ages; about $60 \mathrm{~h}$ at layer top, $80 \mathrm{~h}$ at layer bottom, because of different wind speeds. In the plume, an average mass concentration of $0.19 \mathrm{mg} \mathrm{m}^{-3}$ was determined from the in-situ measurements (case $\mathrm{M}$ ), with maximum concentrations reaching $0.54 \mathrm{mg} \mathrm{m}^{-3}$. $\mathrm{SO}_{2}$ mixing ratios were up to $66 \mathrm{nmol} \mathrm{mol}^{-1}$ (based on 10-s averages). The in-situ aerosol measurements showed a thick ash layer reaching from 3.3 to $6.5 \mathrm{~km}$ altitude with highly elevated particle 

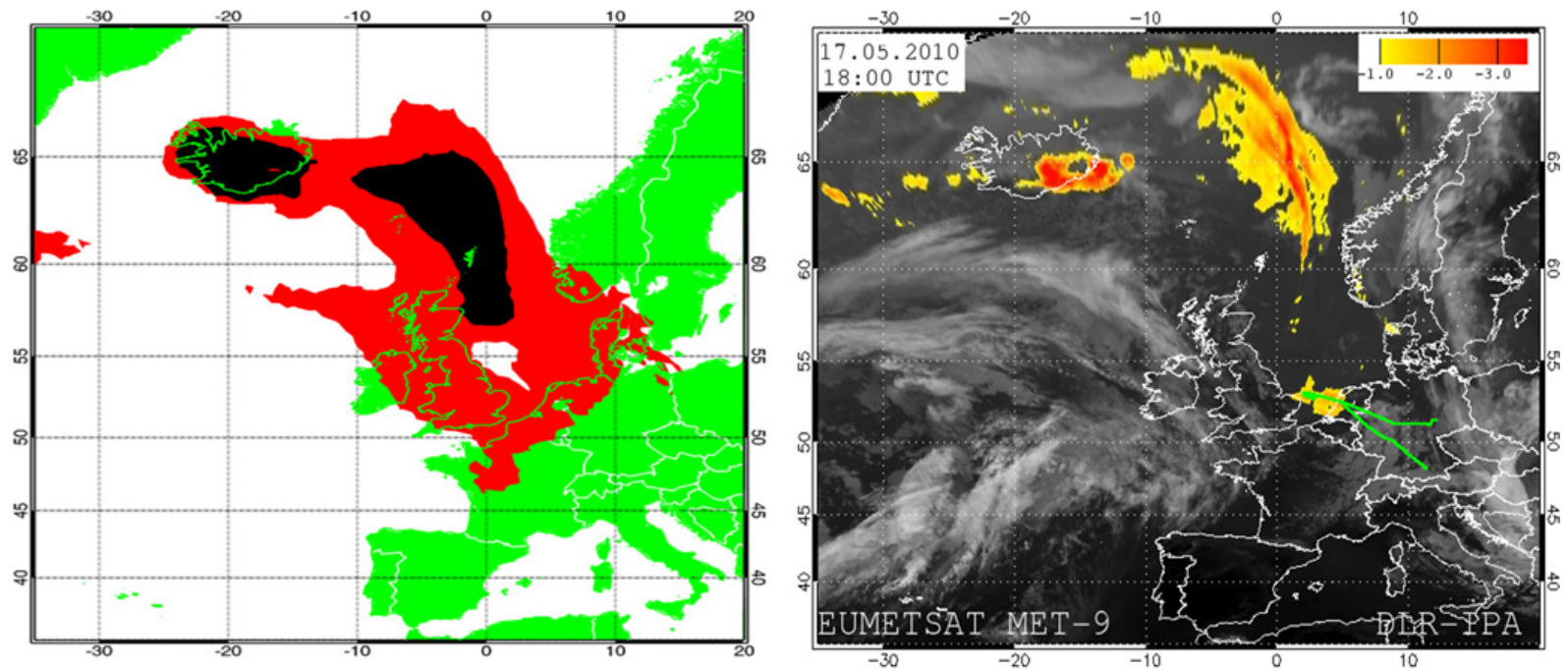

Fig. 15. VAAC prediction (issued at 18:00 UTC 17 May 2010) and Meteosat VA analysis including the Falcon flight path (green curve) for 18:00 UTC 17 May 2010.

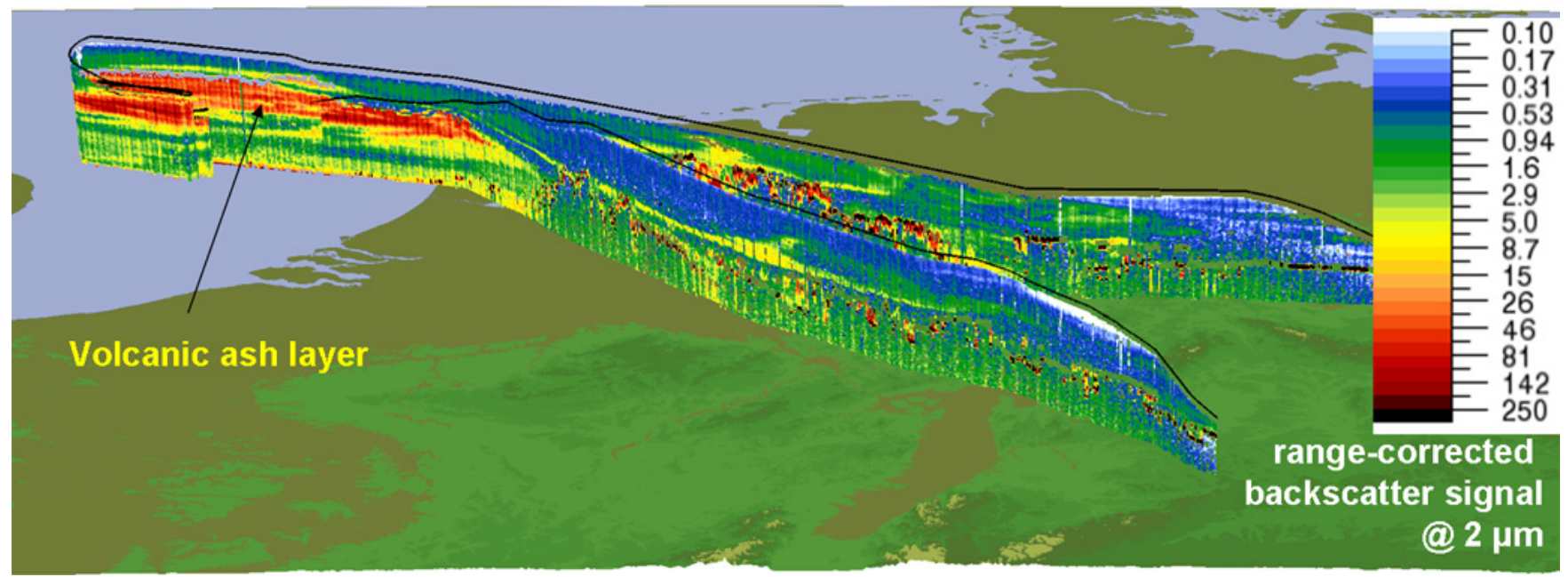

Fig. 16. Lidar cross-section of range corrected backscatter signal along the flight path from Leipzig (Germany) to the North Sea and back to Oberpfaffenhofen near Munich (Germany) in the afternoon of 17 May 2010. The volcanic ash layers over the North Sea are indicated by red and yellow colors. The flight altitude above the North Sea was $8.4 \mathrm{~km}$.

concentrations in all size classes (Fig. 17). The $\mathrm{SO}_{2}$ correlated well with the measured particle concentrations. The 1-h layer-mean $\mathrm{SO}_{2}$ concentration of $27 \mathrm{nmol} \mathrm{mol}^{-1}$ corresponds to about 4.2 Dobson units $\left(1 \mathrm{DU}=2.7 \times 10^{16} \mathrm{~cm}^{-2}\right)$.

\subsubsection{Decreasing ash load of ageing plume over Germany, 18 May}

During 18 May, the plume reached Southern Germany and the Alps. At 00:00 UTC 18 May, the VAAC predicted a "black zone" with ash concentration exceeding $2 \mathrm{mg} \mathrm{m}^{-3}$ over the Netherlands for 12:00 UTC 18 May. Six hours later, the predictions, see Fig. 18, showed lower ash concentrations over the Netherlands. However, the Meteosat ash product of 03:30 UTC 18 May showed the VA maximum further west, at about $48^{\circ} \mathrm{N}, 7^{\circ} \mathrm{W}$, see also Fig. 18. Therefore, a further Falcon flight was performed to check for the ash cloud loading.

The Falcon performed a flight over Germany and the North Sea 07:25-10:34 UTC 18 May. Almost over the entire Falcon flight, multiple VA layers were observed over Germany by the lidar. In a layer over Hamburg, the maximum $\mathrm{SO}_{2}$ mixing ratio reached up to $25 \mathrm{nmol} \mathrm{mol}^{-1}$, the aerosol mass concentrations reached up to $0.11 \mathrm{mg} \mathrm{m}^{-3}$. During the return flight, in southern Germany between 3.5 and $5.2 \mathrm{~km}$ altitude, and descent between Stuttgart and Munich, this ash 
number concentration $/ \mathrm{cm}^{-3}$
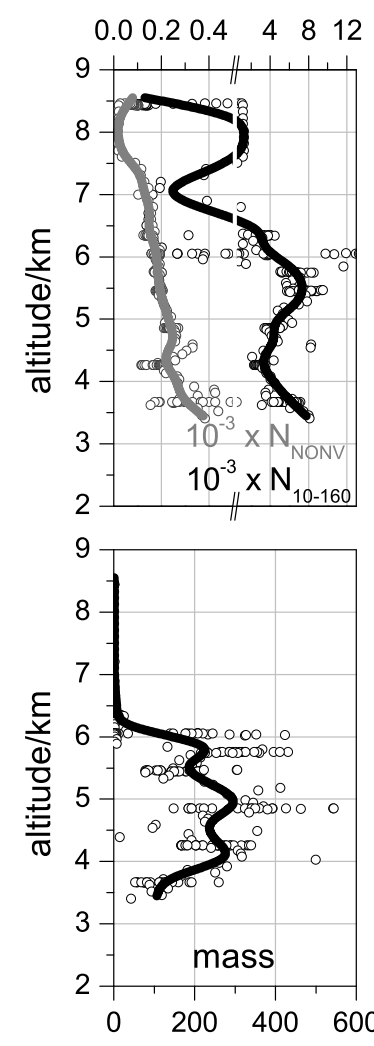

mass conc./( $\left.\mu \mathrm{g} \mathrm{m}^{-3}\right)$
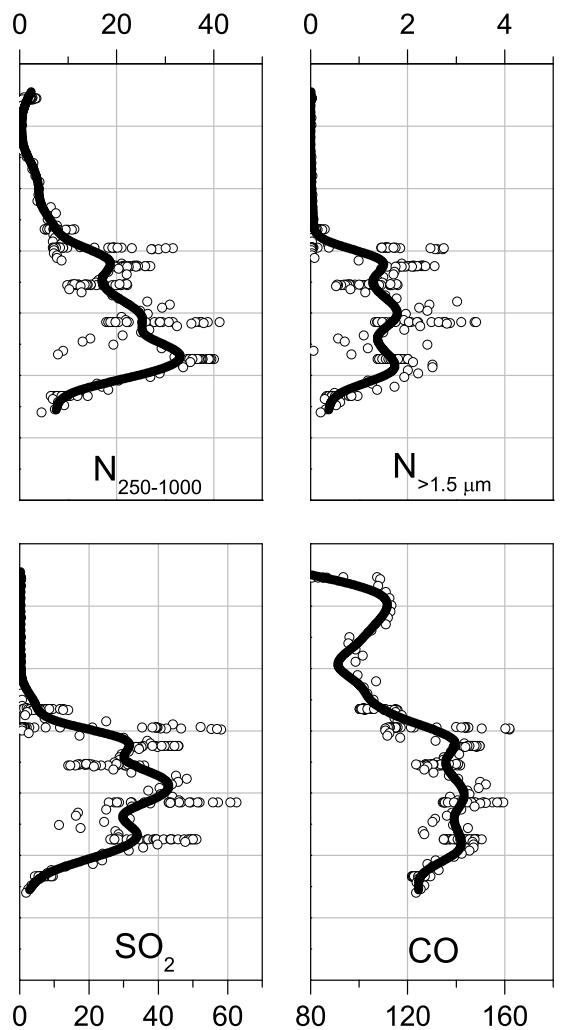

mixing ratio/(nmol $\left.\mathrm{mol}^{-1}\right)$
$\mathrm{RH} / \%$
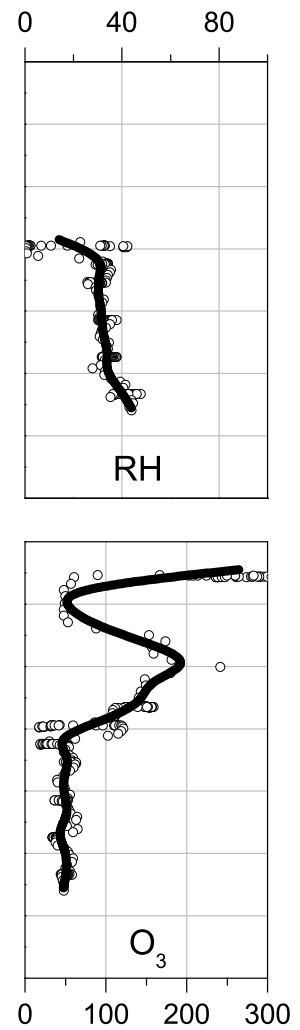

Fig. 17. Number concentrations of total aerosol particles in three size classes $(10-160 \mathrm{~nm}, 0.25-1.0 \mu \mathrm{m}$ and $>1.5 \mu \mathrm{m})$ and non-volatile particles $(>14 \mathrm{~nm}$ ), relative humidity RH, particle mass concentration (case M), and mixing ratios of sulfur dioxide, carbon monoxide and ozone versus altitude during Falcon descent over the North Sea, 15:41:00-16:32:00 UTC 17 May. Dots represent 10-s mean data and curves the 300-m-median.
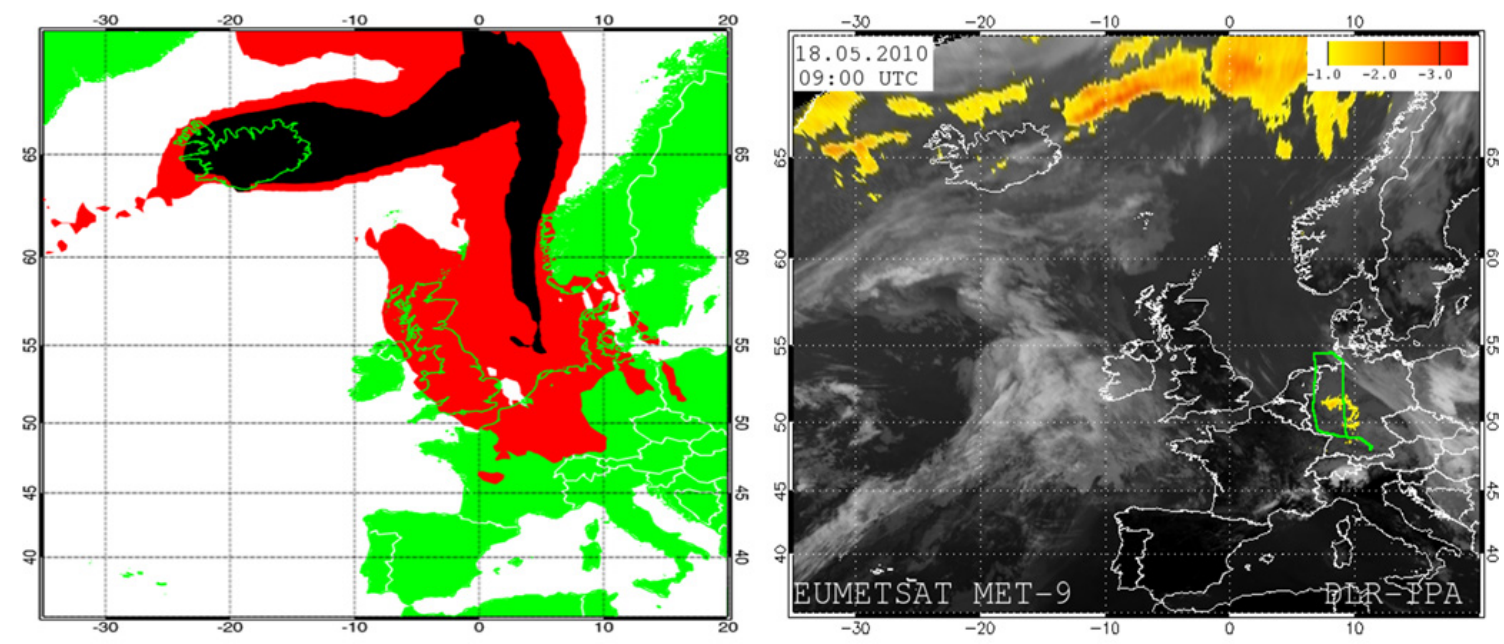

Fig. 18. VAAC prediction (issued at 06:00 UTC 18 May 2010) and Meteosat VA analysis for 09:00 UTC 18 May 2010, including the Falcon flight path. 
plume showed the highest concentration during this flight with 10 -s mean values up to $0.34 \mathrm{mg} \mathrm{m}^{-3}$ for analysis $\mathrm{M}$. The results are consistent with Meteosat ash products, showing dispersed ash traces over Germany between 06:00 and 11:00 UTC 18 May 2010; see Fig. 18. As a whole, the ash clouds were diluted and mass concentrations were lower than over the North Sea area on the previous day.

The Falcon observations are consistent with other ash plume observations the same day. The ash layer was observed by lidar in Jülich around 06:00 UTC (Martina Krämer, personal communication, 2010), above Zurich $\left(47.5^{\circ} \mathrm{N}\right.$, $8.5^{\circ} \mathrm{E}$ ) after about 00:00 UTC 18 May (Thomas Peter, personal communication, 2010), at 07:00 UTC in DWD Ceilometers over western and at 10:00 UTC over southern parts of Germany, and in terms of elevated $\mathrm{SO}_{2}$ above $2 \mathrm{nmol} \mathrm{mol}^{-1}$ at the Schneefernerhaus station $\left(47.4^{\circ} \mathrm{N}\right.$, $11.0^{\circ} \mathrm{E}$ ) (Harald Flentje, personal communication, 2010), and at the Stuttgart lidar between 3.0 and $4.5 \mathrm{~km}$ altitude at 07:40-08:00 UTC (Andreas Behrendt, personal communication, 2010). Measurements by the Swiss MetAir-Dimona aircraft over Switzerland revealed a shallow layer with VA above $3.5 \mathrm{~km}$, first above Bienne $\left(47^{\circ} \mathrm{N}, 7^{\circ} \mathrm{E}\right)$ at $12: 00$ 14:00 UTC; the maximum VA mass concentration was estimated near $0.25 \mathrm{mg} \mathrm{m}^{-3}$; the team also detected increased $\mathrm{CO}_{2}, \mathrm{CO}$, reduced $\mathrm{O}_{3}$, and reduced $\mathrm{H}_{2} \mathrm{O}$ (Bruno Neininger et al., personal communication, 2010). Measurements of particle mass concentrations with a small piston-motor driven aircraft showed inhomogeneous ash layers with concentrations $0.1-0.2 \mathrm{mg} \mathrm{m}^{-3}$ at altitudes slightly above $2.5 \mathrm{~km}$ and increased $\mathrm{SO}_{2}$ column densities over North-West Germany (Weber et al., 2010).

\section{Discussion}

\subsection{Ash mass concentration properties}

As has been pointed out before, it is not possible to measure the ash mass concentration directly. Instead, we derive the ash mass concentration by integration over the volume size distribution deduced from the optical particle counters. We recall that the results of this method depend strongly on the assumed refractive index, in particular the imaginary part, particle bulk mass density and to lesser extent, on the particle shape. We used three different values for the imaginary refractive index in our analysis (Table 5). The density assumed to convert from volume to mass concentrations may be a bit large if the particles are porous or contain large fractions of sulfate. Most critical was the analysis of the FSSP data. In this campaign, the instrument suffered from electronic problems in the largest and smallest channels. Elimination of the largest, incorrect FSSP channels in addition to the smallest ones caused the main difference to the analysis presented in the discussion version of this paper. From the whole set of results, we assume that the best results are close to those for case $\mathrm{M}$ or in between cases $\mathrm{L}$ and $\mathrm{M}$. We have several supporting evidences for this: The refractive index values derived from the single particle analysis (Table 4) are between those values assumed for cases L and M. The FSSP signals are clearly correlated with all other signals $\left(\mathrm{SO}_{2}\right.$, CO, OPC, PCASP) when entering volcanic ash plumes (see Figs. 11, 13 and 17). Outside of clouds or volcanic aerosol plumes, the FSSP did not show any counts. With the present analysis method, the FSSP-300 used shows results consistent with FSSP-100 data measured in boundary layer coarse mode aerosol after the volcanic period. The maximum particle size measured on 2 May is consistent with the size of particles collected (Fig. 4). The maximum particle sizes in all VA plumes detected with the FSSP $(23 \mu \mathrm{m}$, case M) are consistent with the 2D-C probe, with a lower detection size of about $25 \mu \mathrm{m}$, which did not show a single particle count in any of the VA layers measured. The volume size spectra reach their maximum values at sizes below the maximum size, with log-normal approximations showing small mass outside the range resolved, at least for cases $\mathrm{L}$ and $\mathrm{M}$.

Special attention requires the fact, that practically all volume size distributions exhibit an asymmetric shape with its maximum close to the upper margin of the entire size range covered by the instruments. Similar findings were reported from other in-situ and remote sensing studies, without further explanation, for volcanic ash (Hobbs et al., 1982, 1991; Watson and Oppenheimer, 2001), and for desert dust (Duce, 1995). On the other hand, log-normal coarse-mode size distributions were derived for the volcanic ash cloud observed over Munich early 17 April 2010 from lidar and sun photometer measurements (Gasteiger et al., 2010). Hence, the observed volume-size spectra shape needs to be explained.

Here we offer an explanation with the effect of sedimentation in a finite and vertically nearly homogeneous ash layer; see Fig. 19: We assume that the measurements occur at a certain level $z_{\mathrm{m}}$ with distance $s$ below the ash-cloud top $z_{\mathrm{t}}$. In the young plume, those particles, which get lost by sedimentation, are replaced by particles of the same size $D$ from above. However, after some time $s / v$ depending on the distance $s$ and the fall velocity $v(D)$, which increases quadratically with diameter $D$, the layer above the level of measurements is depleted from all such large particles (see Fig. 19, left panel for $t>t_{0}$ ). Thereafter, particles falling down are no longer replaced by particles coming from above and then this size class is depleted. This depletion of particles progresses with plume age $t$, see right panel of Fig. 19. It starts in the largest size class and then gradually affects smaller ones. Therefore, after some plume age $t$, the volume size distribution still increases at small sizes with diameter up to a maximum. However, the volume concentration vanishes above the size $D$ for which $t>s / v$. Near the volcano, tephra samples from the ground (see Sect. 1) indicate initial peak diameters $D_{\max }$ of $60-150 \mu \mathrm{m}$. The value of $D_{\max }$ is far larger than maximum particle sizes detected in the airborne measurements. Hence, all our results occur at times when 

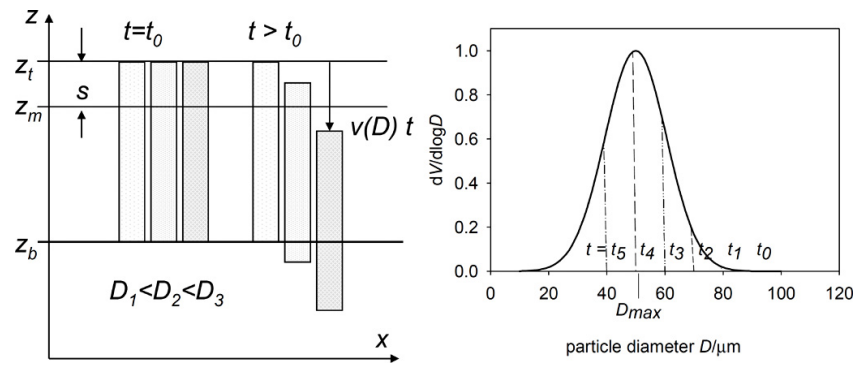

Fig. 19. Schematic explaining the formation of volume size spectra with sudden cut-off near the largest measured diameter $D$. The left panel shows a horizontal ash layer at two times, $t_{0}$ and $t>t_{0}$. The levels of plume top $\left(z_{\mathrm{t}}\right)$, plume bottom $\left(z_{\mathrm{b}}\right)$, and level of measurement $\left(z_{\mathrm{m}}\right)$, are identified, with vertical separation $s=z_{\mathrm{t}}-z_{\mathrm{m}}$. The three rectangles show plume segments with different particle sizes separated in $\mathrm{x}$-direction for illustration. For $t>t_{0}$ the segment with largest particles has been sedimented uniformly over the largest distance $v(D) t$. The right panel shows the volume size distribution starting from an arbitrary initial distribution with maximum volume diameter $D_{\max }$ at $t=t_{0}$. Because of sedimentation, a cut-off forms and gradually ( $t=t_{1}, t_{2}$, etc.) moves to smaller diameters, so that after time $t_{4}$ a volume distribution with maximum at this cut-off evolves.

particles larger than this initial peak size have been lost. If the plume particle distribution is vertically inhomogeneous within the layer, the volume concentration is changed also below the cut-off at earlier times so that the cut-off becomes somewhat smoothed. Turbulent motions may also transport larger particles upward and will further contribute to smooth the size distribution. In order to be comparable to the sedimentation velocity, the vertical turbulent velocities must be larger than $0.1 \mathrm{~m} \mathrm{~s}^{-1}$ for particle sizes larger than $30 \mu \mathrm{m}$. Horizontal mixing with ash-free air outside the plume will reduce the concentrations at all sizes. Hence, the observed behavior of the volume size distributions appears to be reasonable.

The same kind of asymmetric shape of the coarse mode spectrum is found in simulations. Figure 20 shows the measured results for 17 May in comparison to FLEXPART simulation results. Here, the NILU results were taken from the study of Stohl et al. (2011); the DLR results are similar, though computed using different source parameters and size bin resolution. The simulation results are in close agreement with the measured coarse mode results.

Next, we show that the maximum particle sizes derived for case $\mathrm{H}$ are beyond what is expected from sedimentation, while case $\mathrm{M}$ is consistent with this constraint. Because of sedimentation, very large particles would fall below the altitude at which the measurements are performed. Assuming laminar flow and neglecting rarefied gas effects and nonsphericity of the particles, the classical Stokes law (Hinds, 1999), suitable for particle diameters $D<50 \mu \mathrm{m}$, relates the terminal fall velocity $v$ to $D$, gravity $g=9.81 \mathrm{~m} \mathrm{~s}^{-2}$, particle bulk density $\rho_{\mathrm{P}}=2.6 \mathrm{~g} \mathrm{~cm}^{-3}$, and dynamic viscosity of air

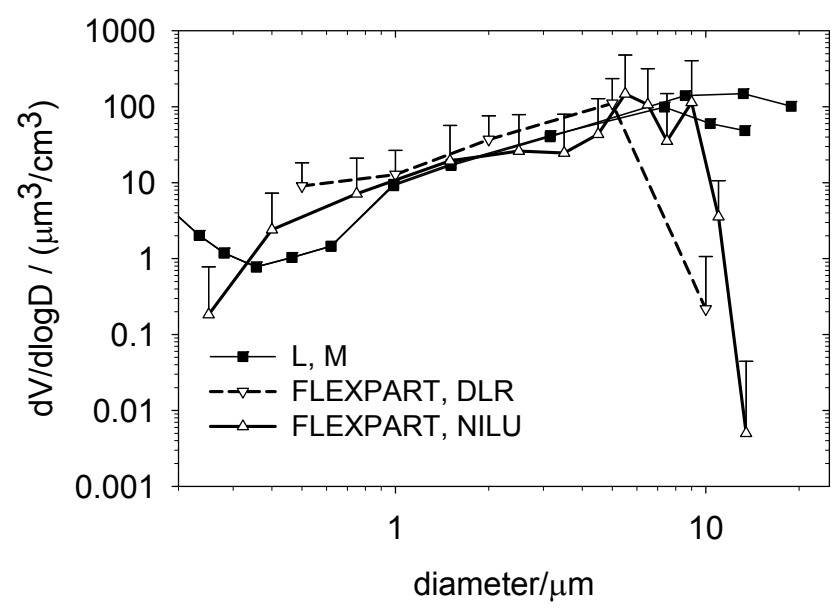

Fig. 20. Volume size spectra as derived from the measurements (L, M) and from simulation (FLEXPART, DLR and NILU) inside the ash cloud (leg 10 of Table 3, 16:11:45-16:19:55 UTC) for 17 May. The higher measured result is for case $M$. The simulations use different ash source parameters. The error bars to the model results reflect the standard deviations along the flight track.

$\eta=14 \times 10^{-6} \mathrm{~kg} \mathrm{~m}^{-1} \mathrm{~s}^{-1}$,

$v=\frac{g \rho_{\mathrm{P}} D^{2}}{18 \eta}$

The fall distance over plume age $t_{\text {age }}$ is $s=v t_{\text {age }}$. Hence, the maximum particle size $D_{\max }$ surviving sedimentation at an altitude $s$ below the initial plume top altitude is about

$D_{\max }=\sqrt{\frac{18 \eta s}{g \rho_{\mathrm{P}} t_{\mathrm{age}}}}$

Inclusion of a shape factor (Hinds, 1999) would increase the values of $D_{\max }$ by about 10 to $30 \%$, which is not essential for this discussion. Figure 21 shows the limiting diameter $D_{\max }$ as a function of age for typical fall distances $s$ of up to $6 \mathrm{~km}$. Since the plume top height was mostly below $10 \mathrm{~km}$ and most of the measurements were performed at 2.6 to $6.5 \mathrm{~km}$, this range should cover all measured cases. The special case of 2 May, with smallest fall distance $(0.2-0.4 \mathrm{~km})$ and smallest plume age (about $0.3 d$ ), is plotted also. Hence, the plumes of ages larger than 2 days should be free of particles larger than $15 \mu \mathrm{m}$ due to sedimentation, unless the particles are porous with significantly smaller effective density.

Observations of elongated volcanic glass particles (equivalent spherical diameter about $50 \mu \mathrm{m}$ ) in ground samples collected in Northern Ireland on 25 April (Davies et al., 2010) would be consistent with our sedimentation estimate assuming a high altitude eruption $(10 \mathrm{~km})$ and short transport time (about $8 \mathrm{~h}$ ) during the early strong wind period. However, our sedimentation model seems to be in conflict with observations of "ultragiant" ash particles of up to about $30 \mu \mathrm{m}$ diameter at more than $1.5 \mathrm{~km}$ altitude which have been derived from radar and lidar observations in Southern Italy, in 


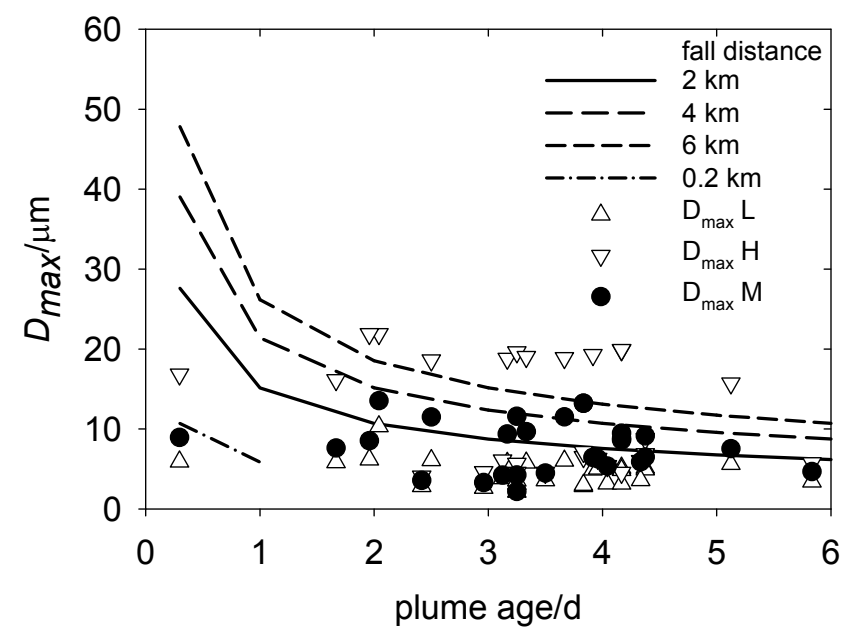

Fig. 21. Sedimentation-limited particle diameter $D_{\max }$ as a function of plume age and fall distance below plume top height. Also plotted are the diameters $D_{\max }$ for which the measured volume size spectra assume their maximum value from the FSSP data for analysis cases $\mathrm{L}, \mathrm{M}$ and $\mathrm{H}$.

four periods from 19 April to 13 May 2010 (Madonna et al., 2010). As a potential explanation, one may consider electrostatic forces. Ash particles have been observed to be electrically charged (Harrison et al., 2010). Charging has been suggested to reduce particle sedimentation (Ulanowski et al., 2007). On the other hand, if charging enhances coagulation between large and small-sized aerosol (Clement et al., 1995), this could also result in larger particles and shorter residence times.

Figure 21 also depicts the values of $D_{\max }$ derived from the measured volume size spectra. The $D_{\max }$ values generally decrease with plume age. A uniform decrease cannot be expected because each plume experienced different vertical synoptic motions, and started from different initial plume altitudes. Moreover, the initial maximum particle size may have changed during the course of the eruption. On the other hand, the results for case $\mathrm{H}$ often exceed the sedimentation limit. This gives strong support that case $\mathrm{H}$ provides upper bound results while cases $\mathrm{M}$ and $\mathrm{L}$ provide best estimate and lower bound results.

\subsection{Comparison with ground-based observations}

Support for the validity of our data, in particular for case $\mathrm{M}$, is also provided by comparing the Falcon in-situ results with ground based data. Figure 22 compares the ash mass concentrations derived from the Falcon in-situ measurements with simultaneous observation results derived from lidar and sun photometer measurements over Leipzig and Munich for 19 April. Here, the Leipzig estimate of mass concentration is based on the analysis of the backscatter and depolarization ratio observations. In the analysis, the backscatter of

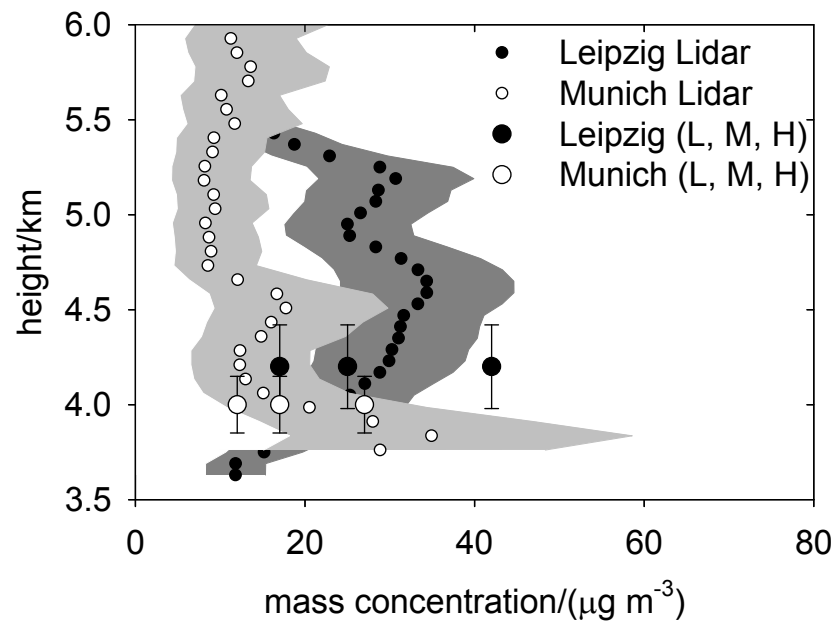

Fig. 22. Comparison of aircraft and ground-based derived ashmass concentration versus altitude. The results are obtained over Leipzig (15:08-15:15 UTC 19 April 2010: dots representing 300m-smoothed results) and Munich (17:34-17:45 UTC same day: every tenth data point after 80 -m-smoothing). The grey shaded areas represent the range of uncertainties of these results. Also shown are the leg-mean mass concentration values derived from the Falcon insitu data for cases $\mathrm{L}, \mathrm{M}$ and $\mathrm{H}$, with vertical error bars indicating the layer depth in which these data were taken (leg 1 and leg 3, Table 3).

non-spherical ash particles and spherical sulfate particles is separated (Tesche et al., 2009). AERONET sun photometer data are analyzed to find the context between ash particle volume concentration (for the vertical column) and the coarse mode-related aerosol optical thickness (Ansmann et al., 2010). The coarse mode volume to optical thickness ratio applied to the ash-related backscatter coefficients (multiplied by the measured extinction-to-backscatter ratios) and multiplied by the ash density of $2.6 \mathrm{~g} \mathrm{~cm}^{-3}$ yields the ash mass concentration shown. The Munich estimate of mass concentration is based on the Klett retrieval (Klett, 1985) of the particle extinction coefficient using the extinction-tobackscatter ratio of $55 \mathrm{sr}$ found for volcanic ash (Wiegner et al., 2011). The resulting particle extinction coefficient is multiplied with the mass-to-extinction conversion factor for volcanic ash of $1.45 \mathrm{~g} \mathrm{~m}^{-2}$ (Gasteiger et al., 2010) to yield the mass concentration. The grey shaded areas indicate the systematic uncertainties of the lidar analysis. The comparison shows fair agreement of the ground-based and aircraftbased ash mass concentration results for all refractive index cases considered, in particular for case $\mathrm{M}$.

Additional support for the validity of our data analysis and further insight are obtained from comparisons of the effective diameter, extinction and backscatter coefficients with ground-based observations of 16/17 April. Values of $D_{\text {eff }}$, derived from the FSSP data for the 34 VA cases are plotted versus ash mass concentration in Fig. 23 and listed for selected cases in Table 3. The effective diameter measures the 


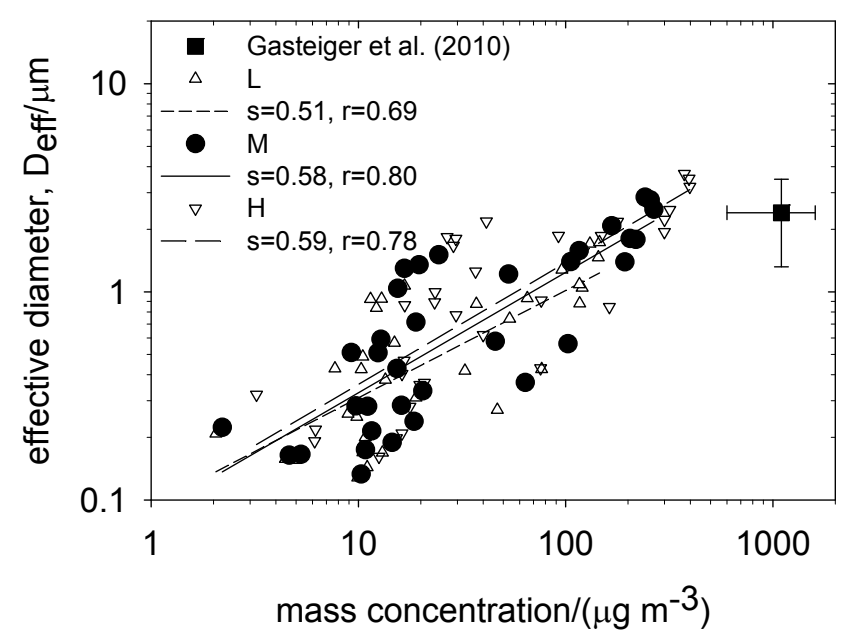

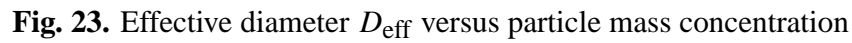
(including Aitken mode particles; FSSP data analyzed for cases L, $\mathrm{M}$, and $\mathrm{H}$ ). The slope $s$ and correlation coefficient $r$ of a linear regression are given. Also included is the result of ground-based observations for Munich, 17 April 2010 (Gasteiger et al., 2010).

ratio of particle volume to particle cross-section area. For the measured size spectra, with rather slow decrease of particle concentration with size, the coarse ash particles contribute most to the volume, while the small (Aitken mode, possibly with a large fraction of sulfate aerosols) particles contribute most to the cross-section area. Including the Aitken mode, the values of $D_{\text {eff }}$ are about $50 \%$ smaller than without this mode. The values vary between $0.2-3 \mu \mathrm{m}$, without systematic trend with plume age. The magnitude of the $D_{\text {eff }}$ values is similar to the values $1-3 \mu \mathrm{m}$ derived from multispectral optical depth analysis for the Mt. Etna aerosol plume (Watson and Oppenheimer, 2001). For comparable ash mass concentrations, our results are only a little larger than those derived from lidar and sun photometer data by Gasteiger et al. (2010) for the Eyjafjalla ash over Munich in the morning of 17 April 2010, see Fig. 23. The value of $D_{\text {eff }}$ increases less than linear (power 0.5-0.6) with the ash mass concentration, but with large scatter. Hence, higher ash concentrations are correlated with larger and more numerous ash particles. The agreement is insensitive to the analysis $\mathrm{L}, \mathrm{M}$ or $\mathrm{H}$, because both the ash concentration and $D_{\text {eff }}$ increase in proportion from case $\mathrm{L}$ to $\mathrm{H}$.

For comparison with extinction coefficients $(\alpha)$ and backscatter coefficients $(\beta)$ derived from ground-based lidar observations, we also compute single-scattering optical properties for the 34 size spectra, for cases $\mathrm{L}, \mathrm{M}$ and $\mathrm{H}$ (Table 5), for $532 \mathrm{~nm}$ wavelength, using the T-matrix approximation for prolate spheres with aspect ratio (largest to smallest diameter) of 1.6. The results were found to be insensitive to the aspect ratio as long as it is significantly larger than one. For constant extinction efficiency $Q_{\text {ext }}$, i.e. in the geometric optics limit with $Q_{\text {ext }}=2$, we would have $\alpha=(3 / 2)$

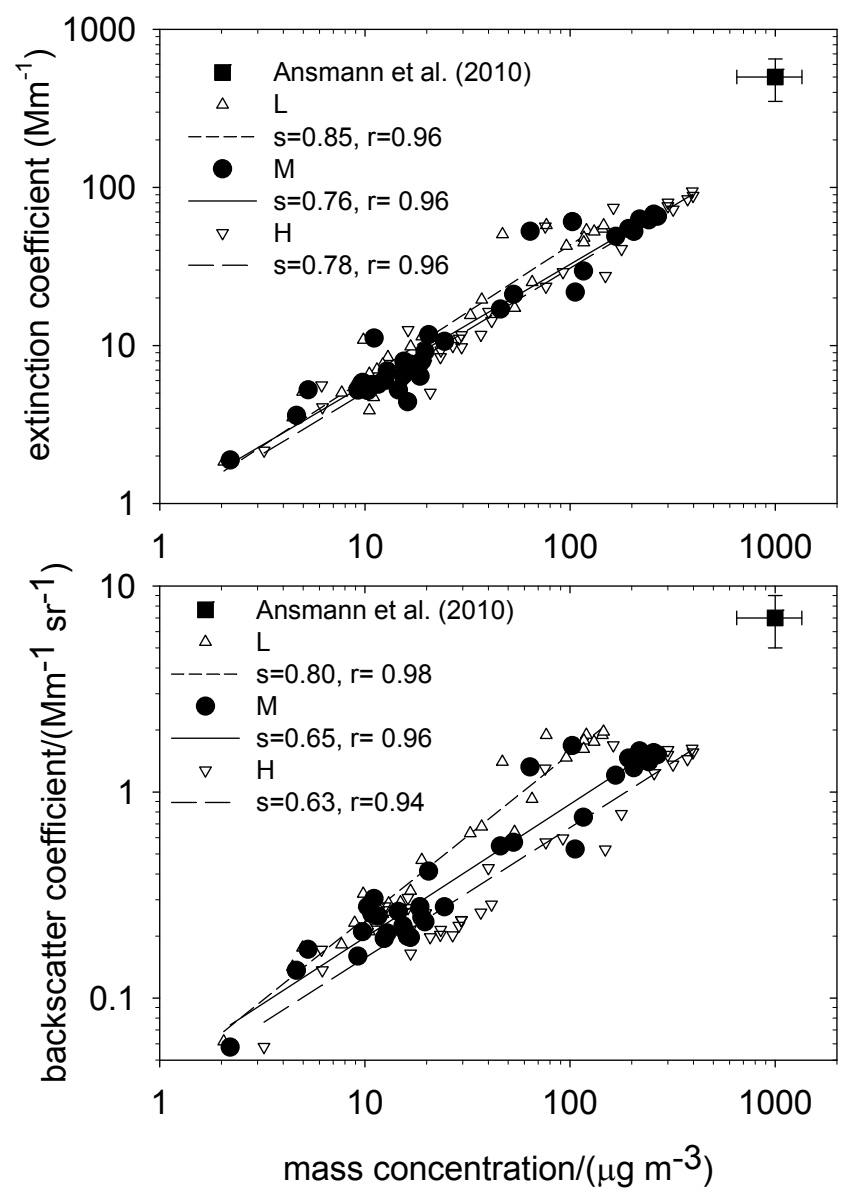

Fig. 24. Extinction coefficient $\alpha$ and backscatter coefficient $\beta$ for $532 \mathrm{~nm}$ wavelength versus particle mass concentration $c$ as computed using T-matrix approximation for prolate spheroids (aspect ratio 1.6), including Aitken, accumulation and coarse mode particles, and various refractive indices and corresponding FSSP data (cases L, M, and H, see Table 5). The slope $s$ and correlation coefficient $r$ of a linear regression are given. Also included are the results of ground-based observations for Leipzig, 16 April 2010 (Ansmann et al., 2010).

$Q_{\text {ext }} \mathrm{c} /\left(\rho_{\mathrm{P}} D_{\text {eff }}\right)$ for given particle density $\rho_{\mathrm{P}}$, ash mass concentration $c$ and effective diameter $D_{\text {eff }}$ (Hansen and Travis, 1974; Schumann et al., 2011). In our cases, the effective size parameters ( $\pi$ times effective diameter over wavelength) are below 17 , so that $Q_{\text {ext }}$ varies considerably with particle sizes. Figure 24 shows that the derived extinction coefficients increase nearly linear with ash mass $c$. This is a consequence of the weak increases of the extinction efficiencies and of $D_{\text {eff }}$ with $c$. For the same reason the extinction-to-mass conversion factor $k=\alpha / c$ decreases (from about $k=1 \mathrm{~m}^{2} \mathrm{~g}^{-1}$ to $0.2 \mathrm{~m}^{2} \mathrm{~g}^{-1}$ for $c=1$ to $1000 \mu \mathrm{g} \mathrm{m}^{-3}$ ) with growing mass concentration $c$. When extrapolated to $c=1000 \mu \mathrm{g} \mathrm{m}^{-3}$, our results for case L imply $\alpha$ of about $300(100-400) \mathrm{Mm}^{-1}$, slightly below the value $500(400-700) \mathrm{Mm}^{-1}$ derived from 


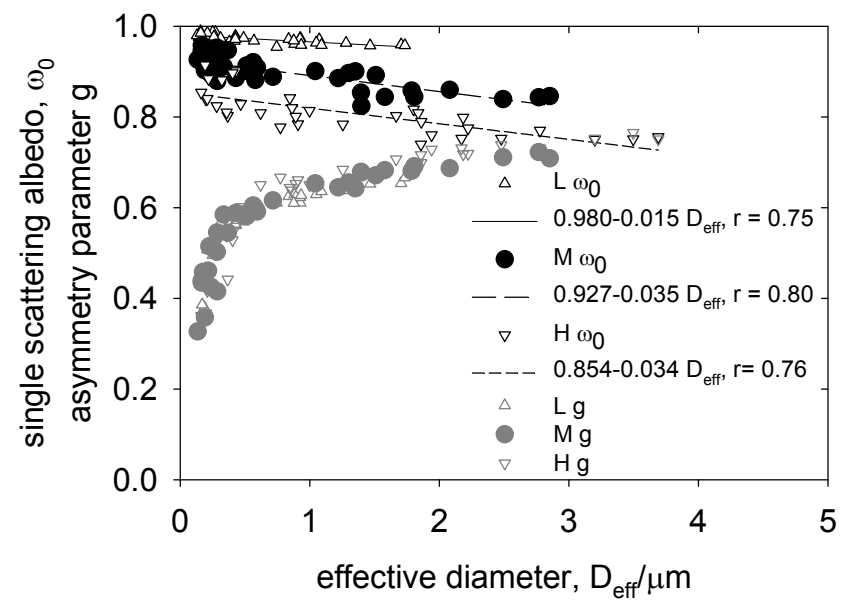

Fig. 25. Single scattering albedo $\omega_{0}$ and asymmetry parameter $g$ for $532 \mathrm{~nm}$ wavelength versus effective diameter $D_{\text {eff }}$. Note, the Tmatrix computations for case $\mathrm{L}$ are performed for an imaginary part of the refractive index of 0.001 . The lines represent least squares fits to the $\omega_{0}$ data versus $D_{\text {eff }}$ (in $\mu \mathrm{m}$ ), with correlation coefficients $r$ as given.

lidar observations over Leipzig and Munich on 16/17 April (Ansmann et al., 2010). Agreement between the lidar and in-situ results is nearly the same for all cases $\mathrm{L}, \mathrm{M}$ and $\mathrm{H}$, but best for case L. Both $\alpha$ and $k$ increase for decreasing val-

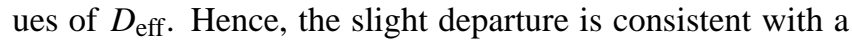
larger $D_{\text {eff }}$ in our measurements compared to the 16/17 April lidar results. Figure 24 also shows the backscattering coefficient computed the same way. The comparison shows that case $\mathrm{H}$ gives too small backscatter. Best agreement with observed data (Ansmann et al., 2010; Gasteiger et al., 2010) is obtained for case $\mathrm{M}$.

As an outlook to further studies, we note that for a $2-\mu \mathrm{m}$ lidar, the extinction and backscatter coefficients have been computed for the size-spectra and found to both increase about linearly with the ash mass concentration. Hence, a 2$\mu \mathrm{m}$ lidar is particular well suited to measure the ash mass concentrations. For a wavelength of $532 \mathrm{~nm}$, the single scattering albedo $\omega_{0}$ decreases about linearly with the product of $D_{\text {eff }}$ and the imaginary part of the refractive index, and the asymmetry parameter $g$ (average cosine of phase function)

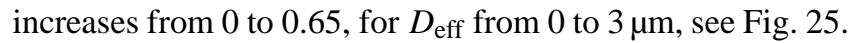
Note, here the T-matrix method is applied for case L with an imaginary part of the refractive index of 0.001 (otherwise $\left.\omega_{0}=1\right)$.

\subsection{Ash mass and trace gas correlations versus plume age}

For aviation safety, it would be desirable to have a parameter indicating volcanic emissions that is more easily measurable than the ash mass concentration. Volcanoes are a major source of $\mathrm{SO}_{2}$ in the atmosphere (Bandy et al., 1982; Hobbs et al., 1982, 1991; Hunton et al., 2005). However, there are

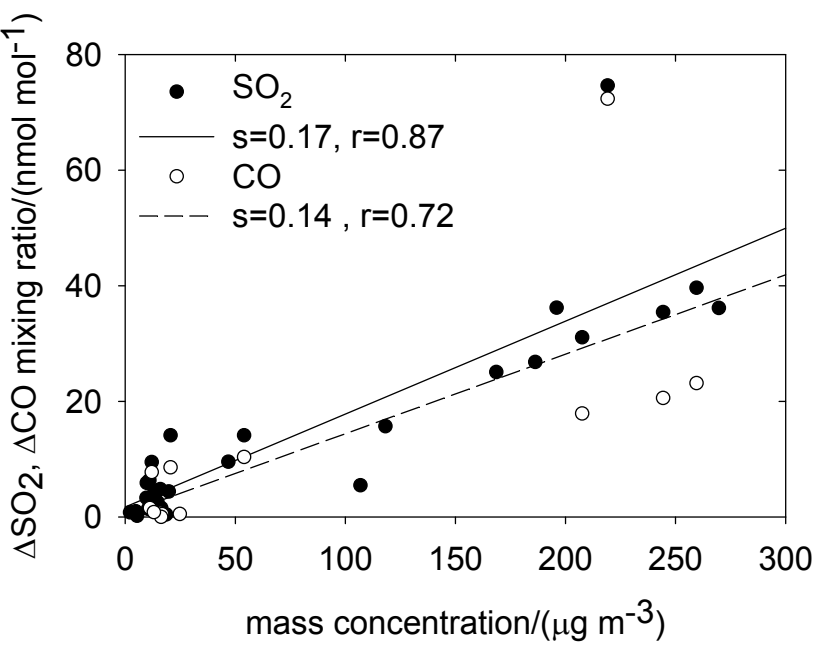

Fig. 26. Correlation between $\mathrm{SO}_{2}$ and $\mathrm{CO}$ mixing ratio increases over background with particle mass concentration (analysis for case $\mathrm{M})$. The points in the upper part of the diagram with largest gas mixing ratios result from the measurements on 2 May. The legend identifies the correlation coefficients $r$ of the linear fits.

documented cases where ash and $\mathrm{SO}_{2}$ separate and travel at different heights in the atmosphere (Prata, 2009). In fact, we too found a few cases with enhanced ash concentration but virtually no $\mathrm{SO}_{2}$ and vice versa (e.g. on 22 April over the Skagerrak and on 13 May over the North Sea). Such separation can be due to particle sedimentation or result from photochemistry and washout. Moreover, the ratio of $\mathrm{SO}_{2}$ to ash concentration likely varies between different volcanoes and eruption periods. Nevertheless, our measurements show some correlation between the $\mathrm{SO}_{2}$ and the ash mass concentrations (see Fig. 26). In logarithmic scales (not plotted), one notes that the correlation is better at higher concentrations (fresh ash plumes). This correlation might be of practical value for rough estimates of ash mass concentration for given $\mathrm{SO}_{2}$ measurements. The latter measurement is far simpler than that of the ash mass.

For this specific volcano and the eruption in April/May 2010, an ash concentration of $1 \mathrm{mg} \mathrm{m}^{-3}$ corresponds to about $170 \mathrm{nmol} \mathrm{mol}^{-1} \mathrm{SO}_{2}$ enhancement in mixing ratio. Hunton et al. (2005) also show a correlation between aerosol volume and $\mathrm{SO}_{2}$ mixing ratio. Their results correspond to only $0.04 \mathrm{mg} \mathrm{m}^{-3}$ increase in aerosol mass for an $\mathrm{SO}_{2}$ enhancement of $170 \mathrm{nmol} \mathrm{mol}^{-1}$, because their particle counters measured only particles smaller than $2 \mu \mathrm{m}$. For $\mathrm{CO}$ enhancement we also find quite large increases inside volcanic plumes (about $140 \mathrm{nmol} \mathrm{mol}^{-1}$ in $\mathrm{CO}$ for $1 \mathrm{mg} \mathrm{m}^{-3}$ of ash mass), at least for young plumes, but the correlation is weaker, and the larger background (order $100 \mathrm{nmol} \mathrm{mol}^{-1}$ ) and its larger variability makes CO less suited for VA detection. The data points in Fig. 26 for ash concentration of $218 \mu \mathrm{g} \mathrm{m}^{-3}$, for 2 May, appear as outliers. This could be caused by measuring in the upper-most 
high- $\mathrm{SO}_{2}$ part of the plume, in which sedimentation reduced the concentrations of large particles.

The mean $\mathrm{SO}_{2}$ mass concentration (computed from the mean measured $\mathrm{SO}_{2}$ mixing ratio and ambient pressure and temperature, for each of the 34 VA cases, excluding 2 May) is 0.25-0.44 times lower than the ash mass concentration based on cases $\mathrm{L}$ and $\mathrm{M}$. Hence, the total ash mass of about 10 (350) Tg implies a total $\mathrm{SO}_{2}$ mass emission of about 3 (0.623) $\mathrm{Tg}$ for the whole April/May 2010 period.

Another simple ash concentration indicator is plume age. In general, one would expect that the concentrations decay with plume age, mainly because of dilution, and in fact, this is generally the case. However, the details depend strongly on the actual volcano source strength feeding the plumes measured, and on the meteorological conditions, as to be expected. For example, the absolute particle concentration was rather modest in the youngest case, over the North Atlantic (2 May) because at the time of leaving the volcano the eruption source strength was well below maximum values. In order to reduce the influence of source strength, we normalize the measured data with the source strength derived from Fig. 2 at the time of emission at the volcano as computed with the HYSPLIT backward trajectories, see Table 3.

Figure 27 shows the concentrations normalized to source strength of 100 units (the maximum value in the complete period, see Fig. 2) versus plume age. We note that the concentrations follow roughly an exponential decay law with half times of a little less than a day. Still, the correlation is quite weak, mainly because of the strong influence of the specific meteorological conditions. Moreover, this result applies to the April/May 2010 Eyjafjalla eruption only. Other decay laws will apply for other volcanoes and other periods.

\section{Conclusions}

Airborne measurements have been performed in VA plumes over Europe between Southern Germany and Iceland during the major eruption period of the Eyjafjalla volcano in April/May 2010. The measurements provided information on the ash plume properties in many respects, in particular the particle properties, the spatial distribution, horizontal and vertical depth, lidar backscatter, particle number-size distribution, mass concentration, mixing ratios of some trace gases $\left(\mathrm{CO}, \mathrm{SO}_{2}, \mathrm{O}_{3}\right)$, and meteorological parameter values including wind profile and relative humidity.

The combination of remote sensing profiling with lidar and in-situ measurements of aerosol and trace gas in-situ instruments including particle impactors turned out to be well suited for this purpose. Lidar observations from above served as pathfinder before the aircraft descended into ash plume layers. The Falcon aircraft being equipped with lidar windows and wing stations to carry optical particle counters to measure large ash particles was essential for this purpose. Particle counters inside the cabin would be insufficient

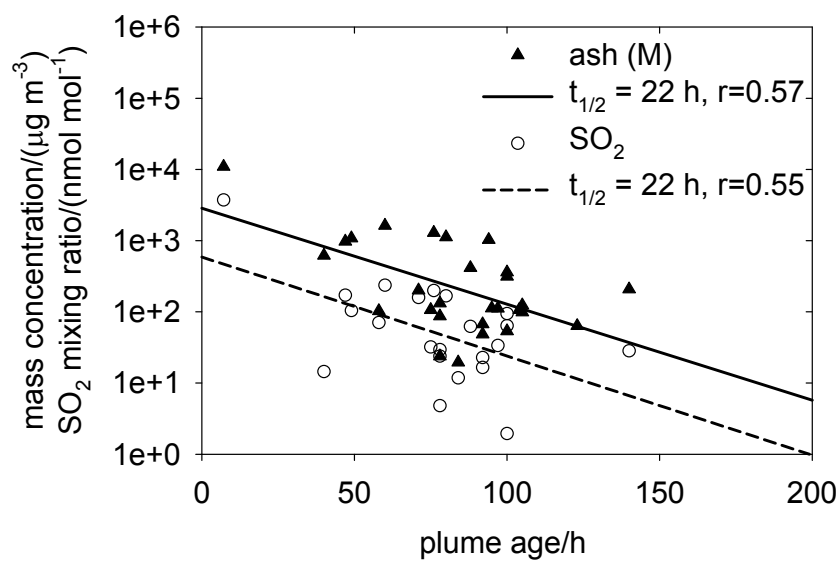

Fig. 27. Normalized (relative to maximum source strength) particle mass concentration (median case $\mathrm{M}$ ) and $\mathrm{SO}_{2}$ mixing ratio versus plume age. The legend identifies the half-value time $t_{1 / 2}$ and the correlation coefficients $r$ of the linear fits.

to measure particles with diameters larger than about 2.5$1.5 \mu \mathrm{m}$ (decreasing with altitude) because of unavoidable losses in the aerosol inlet. Weather and ash plume forecasts and refined satellite observations were essential for flight planning. During analysis, trajectory models were used to identify the plume age, the initial plume release height at the volcano, and the relative eruption source strength. The latter was used for normalization when comparing ash and trace gas concentrations at various plume ages.

The analysis of the coarse-mode size distribution and ash mass concentration from the suite of instruments for optically counting and sizing the particles is highly sensitive to the refractive index and material mass density. Most critical in this respect was the analysis of the FSSP data. Analysis of particles collected by impactors revealed particles up to $20 \mu \mathrm{m}$ at about $10 \mathrm{~h}$ plume age, with size dependent composition, refractive index, and density properties. Ash mass concentration is evaluated for a material density of $2.6 \mathrm{~g} \mathrm{~cm}^{-3}$ and three refractive index values with low, medium and high imaginary parts (Table 5). In addition, as explained in Sect. 3.3, the specific FSSP-300 instrument used in this study suffered from electronic problems in the largest and smallest channels, which were therefore excluded from data analysis in the revised version of this paper. As explained in Sect. 4, we have several supporting evidences for the validity of the particle data derived this way. The remaining uncertainty of the ash mass concentration is estimated to be about a factor of two.

The observations show that the VA cloud spread over large parts of Central Europe, mostly in layers of a few $100 \mathrm{~m}$ to $3 \mathrm{~km}$ depth, at 1 to $7 \mathrm{~km}$ altitude, and typically 100 to $300 \mathrm{~km}$ width. In many cases, the ash plume was several days old, with concentrations below $0.2 \mathrm{mg} \mathrm{m}^{-3}$. The ash was detectable to the combined lidar/in-situ measurements in regions with predicted ash clouds, even at very low 
concentrations of order $0.01 \mathrm{mg} \mathrm{m}^{-3}$. In selected cases, the Falcon flew in ash clouds up to about $0.8 \mathrm{mg} \mathrm{m}^{-3}$ for a few minutes (2 May) and in an ash cloud of about $0.2 \mathrm{mg} \mathrm{m}^{-3}$ mean concentration for about one hour (maximum larger than $0.32 \mathrm{mg} \mathrm{m}^{-3}$, on 17 May 2010). In most cases, the $\mathrm{SO}_{2}$ concentration is well correlated with the ash mass concentration. Typically, $1 \mathrm{mg} \mathrm{m}^{-3}$ ash concentration is related to $170 \mathrm{nmol} \mathrm{mol}^{-1} \mathrm{SO}_{2}$ mixing ratio, and $140 \mathrm{nmol} \mathrm{mol}^{-1} \mathrm{CO}$ mixing ratio increases above background. However, other correlations will apply for other volcanoes and other periods. Under suitable daytime conditions, the ash plume was visible slantwise as faint dark layers even for low concentrations below $0.1 \mathrm{mg} \mathrm{m}^{-3}$. Inside the thicker plumes, visibility was significantly reduced. The ozone concentration and the humidity were often reduced compared to ambient values. A large fraction of volatile particles in the Aitken mode (between 10 and $160 \mathrm{~nm}$ ) was found suggesting that many sulfuric acid droplets formed from the emitted sulfur dioxide. The Aitken mode contributed most of the specific surface area while the coarse mode contributes most of the specific mass. Concentrations of particles in the accumulation mode (100-1000 nm) were rather low. Higher ash concentrations were correlated with larger and more numerous ash particles. Hence, the VA is a rather unusual type of atmospheric aerosol.

The distal ash mass concentration depends on the volcano source strength and the plume age besides many other parameters. To first order ash concentration and the $\mathrm{SO}_{2}$ mixing ratio decreased by a factor of two within less than a day, mainly by dilution. Estimates of the plume volume flux and ash mass fluxes have been provided for the young plume of 1-2 May. The distal ash mass flux was about $500(240-1600) \mathrm{kg} \mathrm{s}^{-1}$, estimated from lidar observations of the plume extent, wind profile, and aerosol backscatter profile, backed by the in-situ observations of the mass concentration in the upper part of the plume. The volcano was only moderately active during the 1-2 May period (but stronger than reported at that time). The initial eruption rate was estimated to about 50 times larger than on these two days. Based on these results and the eruption history as given in Fig. 2, the volcano caused about 10 (2.5-50) Tg of distal ash mass over the April/May period. From the mean mass ratio of $\mathrm{SO}_{2} /$ ash for 33 VA cases, the $\mathrm{SO}_{2}$ mass concentration and emission rate were about a factor 0.16 to 0.25 smaller than for distal ash, implying a total $\mathrm{SO}_{2}$ emission of 3 (0.6-23) Tg in total over the April/May period. Certainly, these values are order of magnitude estimates and have to be checked when the eruption flux history is more accurately quantified in other studies. Taking the best estimate values for granted, they imply that the Eyjafjalla emitted amounts of $\mathrm{SO}_{2}$ larger than those in the recent eruptions of Sarychev: 1.2 Tg (Haywood et al., 2010) and Mt. Kasatochi: $1.5 \mathrm{Tg}$ (Karagulian et al., 2010), but less than Mt. Pinatubo in 1991: 20 Tg, (McCormick et al., 1995), and certainly less than the 1783-1784 Laki eruption in Iceland: $122 \mathrm{Tg}$ (Thordarson and Self, 2003).
The results were used to support aviation agencies in their airspace decisions. The ash mass concentrations derived from the Falcon in-situ data in 34 VA cases from 19 April to 18 May were always smaller than the maximum value of $1.35 \mathrm{mg} \mathrm{m}^{-3}$ derived from ground-based observations over Leipzig and Munich on 16-17 April 2010. From the sum of evidences available during flight (visibility, lidar backscatter, layer depth, particle concentration in the coarse mode, absorption, and $\mathrm{SO}_{2}$ concentration), and comparing to Sahara dust experiences, one could assess early whether the ash loading locally exceeded $0.5 \mathrm{mg} \mathrm{m}^{-3}$ (1, 2, 16 May) or stayed below $0.1 \mathrm{mg} \mathrm{m}^{-3}$ (19, 20, 22 April; 9, 13 May). Besides the measurements, also the fact that the Falcon returned from all the missions without any detectable engine defect from VA supported in assessing aviation safety. In particular, the measurements of 19 April and 9 May over Germany contributed to reopening decisions. The observations of 1-2 May over the North-Atlantic caused an increase of the ash mass source rate used for the VAAC predictions. On the days of 17 and 18 May, a considerable part of air space over Central Europe had more than $0.2 \mathrm{mg} \mathrm{m}^{-3}$ but far less than $2 \mathrm{mg} \mathrm{m}^{-3}$ ash loading. These measurements confirmed VAAC predictions to a degree that closure of air space over Germany could have been avoided. The data described in this paper will be used for further studies, such as validation of satellite and model based studies of the volcanic ash emission sources (Stohl et al., 2011).

Acknowledgements. The measurements were performed on request of the Deutscher Wetterdienst (DWD, German Weather Service) and the Bundesministerium für Verkehr, Bau und Stadtentwicklung (BMVBS, Federal Ministry of Transport, Building and Urban Development). The flight to Iceland was supported by BMVBS and the Icelandic Air Traffic Control Agency, ISAVIA. We gratefully acknowledge the excellent performance of the pilots Steffen Gemsa, Stefan Grillenbeck, Michael Grossrubatscher, Phillip Weber, Roland Welser, the mechanics Alexander Wolf, the flight dispatchers Andrea Hausold and Frank Probst, the Falcon data processing by Andreas Giez, Volker Dreiling, and Martin Zöger, and the 2D-C probe data analysis by Christophe Gourbeyre. Moreover, we are grateful to support by many further colleagues including Andreas Dörnbrack, Andreas Petzold, Anke Roiger, Martin Wirth, Florian Dahlkötter, Klaus-Dirk Gottschaldt, Thomas Hamburger, Patrick Jöckel, Heinrich Brockstieger, Christian Hinz, Wolfgang Schneider, Robert Uebelacker, Josef Wiesmiller, Stephan Bensberg, Heidi Huntrieser, Sigrun Matthes, Hans Volkert, Andreas Schütz and Johann-Dietrich Wörner of DLR, and Nathalie Benker from TU Darmstadt. We thank Andreas Petzold for suggestions improving the paper. Finally, we thank the reviewers for remarks, which helped improving the data analysis and the paper.

Edited by: G. Pappalardo 


\section{References}

Ansmann, A., Tesche, M., Groß, S., Freudenthaler, V., Seifert, P., Hiebsch, A., Schmidt, J., Wandinger, U., Mattis, I., Müller, D., and Wiegner, M.: The 16 April 2010 major volcanic ash plume over central Europe: EARLINET lidar and AERONET photometer observations at Leipzig and Munich, Germany, Geophys. Res. Lett., 37, L13810, doi:10.1029/2010GL043809, 2010.

Arnold, F., Bührke, T., and Qiu, S.: Evidence for stratospheric ozone-depleting heterogeneous chemistry on volcanic aerosols from El Chichón, Nature, 348, 49-50, doi:10.1038/348049a0, 1990.

Balkanski, Y., Schulz, M., Claquin, T., and Guibert, S.: Reevaluation of Mineral aerosol radiative forcings suggests a better agreement with satellite and AERONET data, Atmos. Chem. Phys., 7, 81-95, doi:10.5194/acp-7-81-2007, 2007.

Bandy, A. R., Maroulis, P. J., Wilner, L. A., and Torres, A. L.: Estimates of the fluxes of $\mathrm{NO}, \mathrm{SO}_{2}, \mathrm{H}_{2} \mathrm{~S}, \mathrm{CS}_{2}$ and OCS from Mt. St. Helens deduced from in situ plume concentration measurements, Geophys. Res. Lett., 9, 1097-1100, doi:10.1029/GL009i009p01097, 1982.

Bonasoni, P., Cristofanelli, P., Calzolari, F., Bonafè, U., Evangelisti, F., Stohl, A., Zauli Sajani, S., van Dingenen, R., Colombo, T., and Balkanski, Y.: Aerosol-ozone correlations during dust transport episodes, Atmos. Chem. Phys., 4, 1201-1215, doi:10.5194/acp-4-1201-2004, 2004.

Borrmann, S., Luo, B., and Mishchenko, M.: Application of the T-matrix method to the measurement of aspherical (ellipsoidal) particles with forward scattering optical particle counters, J. Aeros. Sci., 31, 789-799, 2000.

Casadevall, T. J.: Volcanic hazards and aviation safety: Lessons of the past decade, Flight Safety Foundation - Flight Safety Digest, 1-9 May 1993.

Clarke, A. D.: A thermo-optic technique for in situ analysis of sizeresolved aerosol physicochemistry, Atmos. Env., A25, 635-644, 1991.

Clarke, A. D., Charlson, R. J., and Ogren, J. A.: Stratospheric aerosol light absorption before and after El Chichón, Geophys. Res. Lett., 10, 1017-1020, doi:10.1029/GL010i011p01017, 1983.

Clement, C. F., Clement, R. A., and Harrison, R. G.: Charge distributions and coagulation of radioactive aerosols, J. Aeros. Sci., 26, 1207-1225, 1995.

Cronn, D. R. and Nutmagul, W.: Characterization of trace gases in 1980 volcanic plumes of Mt. St. Helens, J. Geophys. Res., 87, 11153-11160, 1982.

Davies, S. M., Larsen, G., Wastegard, S., Turney, C. S. M., Hall, V. A., Coyle, L., and Thordarson, T.: Widespread dispersal of Icelandic tephra: how does the Eyjafjöll eruption of 2010 compare to past Icelandic events?, J. Quat. Sci., 25, 605-611, doi:10.1002/jqs.1421, 2010.

Draxler, R. R.: Evaluation of an ensemble dispersion calculation, J. Appl. Meteorol., 42, 308-317, 2003.

Draxler, R. R. and Hess, G. D.: An overview of the HYSPLIT4 modeling system of trajectories, dispersion, and deposition, Aust. Meteor. Mag., 47, 295-308, 1998.

Duce, R. A.: Sources, distributions, and fluxes of mineral aerosols and their relationship to climate, in: Aerosol Forcing of Climate, edited by: Charlson, R. J. and Heintzenberg, J., Wiley, Chichester, 43-72, 1995.
Dunn, M. G. and Wade, D. P.: Influence of Volcanic Ash Clouds on Gas Turbine Engines, Proceedings of the First International Symposium on Volcanic Ash and Aviation Safety, Washington, 1994.

Durant, A. J., Shaw, R. A., Rose, W. I., Mi, Y., and Ernst, G. G. J.: Ice nucleation and overseeding of ice in volcanic clouds, J. Geophys. Res., 113, D09206, doi:10.1029/2007JD009064, 2008.

Ebert, M., Weinbruch, S., Rausch, A., Gorzawski, G., Helas, G., Hoffmann, P., and Wex, H.: Complex refractive index of aerosols during LACE 98 as derived from the analysis of individual particles, J. Geophys. Res., 107, 8121, doi:10.1029/2000JD000195, 2002.

Fiebig, M.: Das troposphärische Aerosol in mittleren Breiten Mikrophysik, Optik und Klimaantrieb am Beispiel der Feldstudie LACE 98, DLR-Forschungsbericht 2001-23, 259 pp., 2001.

Fiedler, V., Arnold, F., Schlager, H., Dörnbrack, A., Pirjola, L., and Stohl, A.: East Asian $\mathrm{SO}_{2}$ pollution plume over Europe - Part 2: Evolution and potential impact, Atmos. Chem. Phys., 9, 47294745, doi:10.5194/acp-9-4729-2009, 2009.

Flentje, H., Claude, H., Elste, T., Gilge, S., Köhler, U., PlassDülmer, C., Steinbrecht, W., Thomas, W., Werner, A., and Fricke, W.: The Eyjafjallajökull eruption in April 2010 - detection of volcanic plume using in-situ measurements, ozone sondes and lidar-ceilometer profiles, Atmos. Chem. Phys., 10, 1008510092, doi:10.5194/acp-10-10085-2010, 2010.

Gasteiger, J., Groß, S., Freudenthaler, V., and Wiegner, M.: Volcanic ash from Iceland over Munich: mass concentration retrieved from ground-based remote sensing measurements, Atmos. Chem. Phys. Discuss., 10, 26705-26750, doi:10.5194/acpd-10-26705-2010, 2010.

Gayet, J.-F., Shcherbakov, V., Mannstein, H., Minikin, A., Schumann, U., Ström, J., Petzold, A., Ovarlez, J., and Immler, F.: Microphysical and optical properties of midlatitude cirrus clouds observed in the southern hemisphere during INCA, Q. J. R. Meteorol. Soc., 132, 2719-2748, doi:10.1256/qj.05.162, 2006.

Gayet, J.-F., Treffeisen, R., Helbig, A., Bareiss, J., Matsuki, A., Herber, A., and Schwarzenboeck, A.: On the onset of the ice phase in boundary layer Arctic clouds, J. Geophys. Res., 114, D19201, doi:10.1029/2008JD011348, 2009.

Gerbig, C., Schmitgen, S. , Kley, D., Volz-Thomas, A., Dewey, K., and Haaks, D.: An improved fast-response vacuum-UV resonance fluorescence CO instrument, J. Geophys. Res., 104, 16991704, 1999.

Grindle, T. J. and Burcham Jr., F. W.: Even minor volcanic ash encounters can cause major damage to aircraft, ICAO Journal, 7-10 November 2002.

Grindle, T. J. and Burcham Jr., F. W.: Engine Damage to a NASA DC-8-72 Airplane From a High-Altitude Encounter With a Diffuse Volcanic Ash Cloud, National Aeronautics and Space Administration, Dryden Flight Research Center, Edwards, California 93523-0273, NASA/TM-2003-212030, 2003.

Hansen, J. E. and Travis, L. D.: Light scattering in planetary atmospheres, Space Sci. Rev., 16, 527-610, 1974.

Harrison, R. G., Nicoll, K. A., Ulanowski, Z., and Mather, T. A.: Self-charging of the Eyjafjallajökull volcanic ash plume, Environ. Res. Lett., 5, 024004, doi:10.1088/1748-9326/5/2/024004, 2010.

Haywood, J. M., Jones, A., Clarisse, L., Bourassa, A., Barnes, J., Telford, P., Bellouin, N., Boucher, O., Agnew, P., Clerbaux, 
C., Coheur, P., Degenstein, D., and Braesicke, P.: Observations of the eruption of the Sarychev volcano and simulations using the HadGEM2 climate model, J. Geophys. Res., 115, D21212, doi:10.1029/2010JD014447, 2010.

Heue, K.-P., Brenninkmeijer, C. A. M., Baker, A. K., RautheSchöch, A., Walter, D., Wagner, T., Hörmann, C., Sihler, H., Dix, B., Frieß, U., Platt, U., Martinsson, B. G., van Velthoven, P. F. J., Hermann, M., Zahn, A., and Ebinghaus, R.: $\mathrm{SO}_{2}$ and $\mathrm{BrO}$ observation in the plume of the Eyjafjallajökull volcano 2010: CARIBIC and GOME-2 retrievals, Atmos. Chem. Phys. Discuss., 10, 29631-29682, doi:10.5194/acpd-10-29631-2010, 2010a.

Heue, K.-P., Brenninkmeijer, C. A. M., Wagner, T., Mies, K., Dix, B., Frieß, U., Martinsson, B. G., Slemr, F., and van Velthoven, P. F. J.: Observations of the 2008 Kasatochi volcanic $\mathrm{SO}_{2}$ plume by CARIBIC aircraft DOAS and the GOME-2 satellite, Atmos. Chem. Phys., 10, 4699-4713, doi:10.5194/acp-10-4699-2010, 2010b.

Hinds, W. C.: Aerosol Technology, John Wiley \& Sons, New York, 504 pp., 1999.

Hobbs, V. P., Tuell, J., Hegg, D., Radke, L., and Eltgroth, M.: Particles and gases in the emissions from the 1980-1981 volcanic eruptions of Mt. St. Helens, J. Geophys. Res., 87, 11062-11086, 1982.

Hobbs, V. P., Radke, L. F., Lyons, J. H., Ferek, R. J., Coffman, D. J., and Casadevall, T. J.: Airborne measurements of particle and gas emissions from the 1990 volcanic eruptions of Mount Redoubt, J. Geophys. Res., 96, 18735-18752, 1991.

Hunton, D. E., Viggiano, A. A., Miller, T. M., Ballenthin, J. O., Reeves, J. M., Wilson, J. C., Lee, S.-H., Anderson, B. E., Brune, W. H., Harder, H., Simpas, J. B., and Oskarsson, N.: In-situ aircraft observations of the 2000 Mt. Hekla volcanic cloud: Composition and chemical evolution in the Arctic lower stratosphere, J. Volcan. Geothermal Res., 145, 23-34, 2005.

ICAO: Volcanic Ash Contingency Plan - EUR and NAT regions, EUR Doc 019, NAT Doc 006, Part II, International Civil Aviation Authority, Montreal, 1-26, 2010.

Jones, A., Johnson, D., Hort, M., and Devenish, B.: The UK Met Office's Next-Generation Atmospheric Dispersion Model, NAME III, in: Air Pollution Modeling and Its Application XVII, edited by: Borrego, C., and Norman, A.-L., Springer, 580-589, doi:10.1007/978-0-387-68854-1, 2007.

Jurkat, T., Voigt, C., Arnold, F., Schlager, H., Aufmhoff, H., Schmale, J., Schneider, J., Lichtenstern, M., and Dörnbrack, A.: Airborne stratospheric ITCIMS-measurements of $\mathrm{SO}_{2}, \mathrm{HCl}$, and $\mathrm{HNO}_{3}$ in the aged plume of volcano Kasatochi, J. Geophys. Res., 115, D00L17, doi:10.1029/2010JD013890, 2010.

Kandler, K., Schütz, L., Deutscher, C., Ebert, M., Hofmann, H., Jäckel, S., Jaenicke, R., Knippertz, P., Lieke, K., Massling, A., Petzold, A., Schladizt, A., Weinzierl, B., Wiedensohler, A., Zorn, S., and Weinbruch, S.: Size distribution, mass concentration, chemical and mineralogical composition and derived optical parameters of the boundary layer aerosol at Tinfou, Morocco, during SAMUM, Tellus, 61B, 32-50, 10.1111/j.16000889.2008.00385.x, 2009.

Karagulian, F., Clarisse, L., Clerbaux, C., Prata, A. J., Hurtmans, D., and Coheur, P. F.: Detection of volcanic $\mathrm{SO}_{2}$, ash, and $\mathrm{H}_{2} \mathrm{SO}_{4}$ using the Infrared Atmospheric Sounding Interferometer (IASI), J. Geophys. Res., 115, D00L02,
doi:10.1029/2009JD012786, 2010.

Klett, J. D.: Lidar inversion with variable backscatter/extinction ratios, Appl. Opt., 24, 1638-1643, doi:10.1364/AO.24.001638, 1985.

Köpp, F., Rahm, S., and Smalikho, I.: Characterization of aircraft wake vortices by $2-\mu \mathrm{m}$ pulsed Doppler lidar, J. Atmos. Ocean. Techn., 21, 194-206, 2004.

Kotra, J. P., Finnigan, D. L., Zoller, W. H., Hart, M. A., and Moyers, J. L.: El Chichón: Composition of plume gases and particles, Science, 222, 1018-1021, doi:10.1126/science.222.4627.1018, 1983.

Krotkov, N. A., Flittner, D. E., Krueger, A. J., Kostinski, A., Riley, C., Rose, W., and Torres, O.: Effect of particle non-sphericity on satellite monitoring of drifting volcanic ash clouds, J. Quant. Spectrosc. Radiat. Transf., 63, 613-630, 1999.

Lawson, R. P., O’Connor, D., Zmarzly, P., Weaver, K., Baker, B., Mo, Q., and Jonsson, H.: The 2D-S (stereo) probe: Design and preliminary tests of a new airborne, high-speed, high-resolution particle imaging probe, J. Atmos. Ocean. Techn., 23, 1462-1477, 2006.

Lilly, D. K.: Cirrus outflow dynamics, J. Atmos. Sci., 45, 1594$1605,1988$.

Luke, W. T.: Evaluation of a commercial pulsed fluorescence detector for the measurements of low-level $\mathrm{SO}_{2}$ concentrations during the Gas-Phase Sulfur Intercomparison Experiment, J. Geophys. Res., 102, 16255-16265, 1997.

Madonna, F., A. Amodeo, D'Amico, G., Mona, L., and Pappalardo, G.: Observation of non-spherical ultragiant aerosol using a microwave radar, Geophys. Res. Lett., 37, L21814, doi:10.1029/2010GL044999, 2010.

Martinsson, B. G., Brenninkmeijer, C. A. M., Carn, S. A., Hermann, M., Heue, K.-P., Velthoven, P. F. J. V., and Zahn, A.: Influence of the 2008 Kasatochi volcanic eruption on sulfurous and carbonaceous aerosol constituents in the lower stratosphere, Geophys. Res. Lett., 36, L12813, doi:10.1029/2009GL038735, 2009.

Mason, B. G., Pyle, D. M., and Oppenheimer, C.: The size and frequency of the largest explosive eruptions on Earth, Bull. Volcanol., 66, 735-748, doi:10.1007/s00445-004-0355-9, 2004.

Mastin, L. G., Guffanti, M., Servranckx, R., Webley, P., Barsotti, S., Dean, K., Durant, A., Ewert, J. W., Neri, A., Rose, W. I., Schneider, D., Siebert, L., Stunder, B., Swanson, G., Tupper, A., Volentik, A., and Waythomas, C. F.: A multidisciplinary effort to assign realistic source parameters to models of volcanic ash-cloud transport and dispersion during eruptions, J. Volcan. Geothermal Res., 186, 10-21, doi:10.1016/j.jvolgeores.2009.01.008, 2009.

Mattis, I., Siefert, P., Müller, D., Tesche, M., Hiebsch, A., Kanitz, T., Schmidt, J., Finger, F., Wandinger, U., and Ansmann, A.: Volcanic aerosol layers observed with multiwavelength Raman lidar over central Europe in 2008-2009, J. Geophys. Res., 115, D00L04, doi:10.1029/2009JD013472, 2010.

McCormick, M. P., Thomason, L. W., and Trepte, C. R.: Atmospheric effects of the Mt Pinatubo eruption, Nature 373, 399404, doi:10.1038/373399a0, 1995.

McFarquhar, G. M. and Heymsfield, A. J.: The definition and significance of an effective radius for ice clouds, J. Atmos. Sci., 55, 2039-2052, 1998.

Minikin, A., Petzold, A., Ström, J., Krejci, R., Seifert, M., Velthoven van, P., Schlager, H., and Schumann, U.: Aircraft observations of the upper tropospheric fine particle aerosol in 
the northern and southern hemispheres at midlatitudes, Geophys. Res. Lett., 30, 1503, doi:10.1029/2002g1016458, 2003.

Mishchenko, M. I. and Travis, L. D.: Light scattering by polydispersions of randomly oriented spheroids with sizes comparable to wavelenghts of observation, Appl. Opt., 33, 7206-7225, 1994.

Mishchenko, M. I. and Travis, L. D.: Capabilities and limitations of a current FORTRAN implementation of the T-matrix method for randomly oriented, rotationally symmetric scatterers, J. Quant. Spectrosc. Radiat. Transf., 60, 309-324, doi:10.1016/S00224073(98)00008-9, 1998.

Munoz, O., Volten, H., Hovenier, J. W., Veihelmann, B., Zande, W. J. V. D., Waters, L. B. F. M., and Rose, W. I.: Scattering matrices of volcanic ash particles of Mount St. Helens, Redoubt, and Mount Spurr Volcanoes, J. Geophys. Res., 109, D16201, doi:10.1029/2004JD004684, 2004.

Ouimette, J. R. and Flagan, R. C.: The extinction coefficient of multicomponent aerosols, Atmos. Env., 16, 2405-2419, 1982.

Patterson, E. M.: Optical properties of the crustal aerosol: Relation to chemical and physical characteristics, J. Geophys. Res., 86, 3236-3246, doi:10.1029/JC086iC04p03236, 1981.

Patterson, E. M., Pollard, C. O., and Galindo, I.: Optical properties of the ash from El Chichón Volcano, Geophys. Res. Lett., 10, 317-320, doi:10.1029/GL010i004p00317, 1983.

Petzold, A., Rasp, K., Weinzierl, B., Esselborn, M., Hamburger, T., Dörnbrack, A., Kandler, K., Schütz, L., Knippertz, P., Fiebig, M., and Virkkula, A.: Saharan dust absorption and refractive index from aircraft-based observations during SAMUM 2006, Tellus, 61B, 118-130, doi:10.1111/j.1600-0889.2008.00383.x, 2009.

Pieri, D., Ma, C., Simpson, J. J., Hufford, G., Grindle, T., and Grove, C.: Analyses of in-situ airborne volcanic ash from the February 2000 eruption of Hekla Volcano, Iceland, Geophys. Res. Lett., 29, 1767, doi:10.1029/2001GL013688, 2002.

Pollack, J. B., Toon, O. B., and Khare, B. N.: Optical properties of some terrestrial rocks and glasses, Icarus, 19, 372-389, 1973.

Prata, A. J.: Satellite detection of hazardous volcanic clouds and the risk to global air traffic, Natural Hazards, 51, 303-324, doi:10.1007/s11069-008-9273-z, 2009.

Prata, A. J. and Grant, I. F.: Retrieval of microphysical and morphological properties of volcanic ash plumes from satellite data: Application to Mt. Ruapehu, New Zealand, Q. J. R. Meteorol. Soc., 127, 2153-2179, 2001.

Przedpelski, Z. J. and Casadevall, T. J.: Impact of volcanic ash from 15 December 1989 Redoubt volcano eruption on GE CF6-80C2 turbofan engines, Proceedings of the First International Symposium on Volcanic Ash and Aviation Safety, Washington, 1994.

Reitebuch, O., Werner, C., Leike, I., Delville, P., Flamant, P. H., Cress, A., and Engelbart, D.: Experimental validation of wind profiling performed by the airborne $10-\mu$ m-heterodyne Doppler lidar WIND, J. Atmos. Ocean. Techn., 18, 1331-1344, 2001.

Reitebuch, O., Lemmerz, C., Nagel, E., Paffrath, U., Durand, Y., Endemann, M., Fabre, F., and Chaloupy, M.: The Airborne Demonstrator for the Direct-Detection Doppler Wind Lidar ALADIN on ADM-Aeolus: I. Instrument design and comparison to satellite instrument, J. Atmos. Ocean. Techn., 26, 2501-2515, doi:10.1175/2009JTECHA1309.1, 2009.

Roiger, A.: Shipboard sulfur dioxide measurements in the North Atlantic marine boundary layer, Master thesis, Munich University of Applied Sciences, 2007.

Rose, W. I. and Durant, A. J.: Fine ash content of ex- plosive eruptions, J. Volcan. Geothermal Res., 186, 32-39, doi:10.1016/j.jvolgeores.2009.01.010, 2009.

Rose, W. I., Millard, G. A., Mather, T. A., Hunton, D. E., Anderson, B., Oppenheimer, C., Thornton, B. F., Gerlach, T. M., Viggiano, A. A., Kondo, Y., Miller, T. M., and Ballenthin, J. O.: Atmospheric chemistry of a 33-34 hour old volcanic cloud from Hekla Volcano (Iceland): Insights from direct sampling and the application of chemical box modeling, J. Geophys. Res., 111, D20206, doi:10.1029/2005JD006872, 2006.

Schlager, H., Konopka, P., Schulte, P., Schumann, U., Ziereis, H., Arnold, F., Klemm, M., Hagen, D. E., Whitefield, P. D., and Ovarlez, J.: In situ observations of air traffic emission signatures in the North Atlantic flight corridor, J. Geophys. Res., 102, 10739-10750, 1997.

Schmale, J., Schneider, J., Jurkat, T., Voigt, C., Kalesse, H., Rautenhaus, M., Lichtenstern, M., Schlager, H., Ancellet, G., Arnold, F., Gerding, M., Mattis, I., Wendisch, M., and Borrmann, S.: Aerosol layers from the 2008 eruptions of Mount Okmok and Mount Kasatochi: In situ upper troposphere and lower stratosphere measurements of sulfate and organics over Europe, J. Geophys. Res., 115, D00L07, doi:10.1029/2009JD013628, 2010.

Schröder, F. and Ström, J.: Aircraft measurements of sub micrometer aerosol particles $(>7 \mathrm{~nm})$ in the midlatitude free troposphere and tropopause region, Atmos. Res., 44, 333-356, 1997.

Schumann, U., Arnold, F., Busen, R., Curtius, J., Kärcher, B., Curtius, J., Petzold, A., Schlager, H., Schröder, F., and Wohlfrom, K. H.: Influence of fuel sulfur on the composition of aircraft exhaust plumes: The experiments SULFUR 1-7, J. Geophys. Res., 107, 4247, doi:10.1029/2001JD000813, 2002.

Schumann, U., Mayer, B., Gierens, K., Unterstrasser, S., Jessberger, P., Petzold, A., and Voigt, C.: Effective radius of ice particles in cirrus and contrails, J. Atmos. Sci., 68, 300-321, doi:10.1175/2010JAS3562.1, 2011.

Schütz, L.: Long range transport of desert dust with special emphasis on the Sahara, Annals of The New York Academy of Sciences, 338, 515-532, doi:10.1111/j.1749-6632.1980.tb17144.x, 1980.

Seibert, P. and Frank, A.: Source-receptor matrix calculation with a Lagrangian particle dispersion model in backward mode, Atmos. Chem. Phys., 4, 51-63, doi:10.5194/acp-4-51-2004, 2004.

Sigmundsson, F., Hreinsdóttir, S., Hooper, A., Árnadóttir, T., Pedersen, R., Roberts, M. J., Óskarsson, N., Auriac, A., Decriem, J., Einarsson, P., Geirsson, H., Hensch, M., Ófeigsson, B. G., Sturkell, E., Sveinbjörnsson, H., and Feigl, K. L.: Intrusion triggering of the 2010 Eyjafjallajökull explosive eruption, Nature, 468, 426-430, doi:10.1038/nature09558, 2010.

Sokolik, I. N. and Toon, O. B.: Incorporation of mineralogical composition into models of the radiative properties of mineral aerosol from UV to IR wavelengths, J. Geophys. Res., 104, 9423-9444, doi:10.1029/1998JD200048, 1999.

Sparks, R. S. J., Bursik, M. I., Carey, S. N., Gilbert, J. S., Graze, L. S., Sigurdsson, H., and Woods, A. W.: Volcanic Plumes, J. Wiley and Sons, Chichester, 574 pp., 1997.

Stohl, A., Forster, C., Eckhardt, S., Spichtinger, N., Huntrieser, H., Heland, J., Schlager, H., Wilhelm, S., Arnold, F., and Cooper, O.: A backward modeling study of intercontinental pollution transport using aircraft measurements, J. Geophys. Res., 108, 4370, doi:10.1029/2002JD002862, 2003. 
Stohl, A., Forster, C., Frank, A., Seibert, P., and Wotawa, G.: Technical note: The Lagrangian particle dispersion model FLEXPART version 6.2, Atmos. Chem. Phys., 5, 2461-2474, doi:10.5194/acp-5-2461-2005, 2005.

Stohl, A., Prata, A. J., Eckhardt, S., Clarisse, L., Durant, A., Henne, S., Kristiansen, N. I., Minikin, A., Schumann, U., Seibert, P., Stebel, K., Thomas, H. E., Thorsteinsson, T., Tørseth, K., and Weinzierl, B.: Determination of time- and height-resolved volcanic ash emissions for quantitative ash dispersion modeling: the 2010 Eyjafjallajökull eruption, Atmos. Chem. Phys. Discuss., 11, 5541-5588, doi:10.5194/acpd-11-5541-2011, 2011.

Tesche, M., Ansmann, A., Müller, D., Althausen, D., Engelmann, R., Freudenthaler, V., and Groß, S.: Vertically resolved separation of dust and smoke over Cape Verde using multiwavelength Raman and polarization lidars during Saharan Mineral Dust Experiment 2008, J. Geophys. Res., 114, D13202, doi:10.1029/2009JD011862, 2009.

Thordarson, T., and Self, S.: Atmospheric and environmental effects of the 1783-1784 Laki eruption: A review and reassessment, J. Geophys. Res., 108, 4011, doi:10.1029/2001JD002042, 2003.

Tröger, W. E.: Optische Bestimmung der gesteinsbildenden Minerale Teil I.: Bestimmungstabellen, edited by: Bambauer, H. U., Taborszky, F., and Trochim, H.-D., Schweitzerbartsche Verlagsbuchhandlung, Stuttgart, 1982.

Ulanowski, Z., Bailey, J., Lucas, P. W., Hough, J. H., and Hirst, E.: Alignment of atmospheric mineral dust due to electric field, Atmos. Chem. Phys., 7, 6161-6173, doi:10.5194/acp-7-6161-2007, 2007.

Virkkula, A.: Correction of the calibration of the 3-wavelength Particle Soot Absorption Photometer ( $3 \lambda$ PSAP), Aerosol Sci. Techn., 44, 706-712, 2010.

Voigt, C., Schumann, U., Jurkat, T., Schäuble, D., Schlager, H., Petzold, A., Gayet, J.-F., Krämer, M., Schneider, J., Borrmann, S., Schmale, J., Jessberger, P., Hamburger, T., Lichtenstern, M., Scheibe, M., Gourbeyre, C., Meyer, J., Kübbeler, M., Frey, W., Kalesse, H., Butler, T., Lawrence, M. G., Holzäpfel, F., Arnold, F., Wendisch, M., Döpelheuer, A., Gottschaldt, K., Baumann, R., Zöger, M., Sölch, I., Rautenhaus, M., and Dörnbrack, A.: In-situ observations of young contrails - overview and selected results from the CONCERT campaign, Atmos. Chem. Phys., 10, 90399056, doi:10.5194/acp-10-9039-2010, 2010. von Glasow, R.: Atmospheric chemistry in volcanic plumes, P. Natl. Acad. Sci. USA, 107, 6594-6599, 2010.

Watson, I. M. and Oppenheimer, C.: Photometric observations of Mt. Etna's different aerosol plumes, Atmos. Env., 35, 35613572, 2001.

Weber, K., Vogel, A., Fischer, C., Haren, G. V., and Pohl, T.: Airborne measurements of the Eyjafjallajökull volcanic ash plume over North-Western Germany with a light aircraft and an optical particle counter - first results, Proceedings of the International Conference on Lidar Technologies, Techniques, and Measurements for Atmospheric Remote Sensing, Toulouse, France, 2010.

Webley, P. and Mastin, L.: Improved prediction and tracking of volcanic ash clouds, J. Volcan. Geothermal Res., 186, 1-9, 2009.

Weinzierl, B., Petzold, A.,Esselborn, M., Wirth, M., Rasp, K., Kandler, L., Schütz, L., Koepke, P., and Fiebig, M.: Airborne measurements of dust layer properties, particle size distribution and mixing state of Saharan dust during SAMUM 2006, Tellus, 61B, 96-117, doi:10.1111/j.1600-0889.2008.00392.x, 2009.

Weissmann, M., Braun, F. J., Gantner, L., Mayr, G., Rahm, S., and Reitebuch, O.: The Alpine mountain-plain circulation: Airborne Doppler lidar measurements and numerical simulations, Mon. Wea. Rev., 133, 3095-3109, 2005a.

Weissmann, M., Busen, R., Dörnbrack, A., Rahm, S., and Reitebuch, O.: Targeted observations with an airborne wind lidar, J. Atmos. Ocean. Techn., 22, 1706-1719, 2005b.

Wendisch, M., Coe, H., Baumgardner, D., Brenguier, J. L., Dreiling, V., Fiebig, M., Formenti, P., Hermann, M., Kraemer, M., Levin, Z., Maser, R., Mathieu, E., Nacvass, P., Noone, K., Osborne, S., Schneider, J., Schütz, L., Schwarzenböck, A., Stratmann, F., and Wilson, J. C.: Supplement to aircraft particle inlets: State-ofthe-art and future needs, Bull. Amer. Meteorol. Soc., 85, p. 92, 2004.

Wiegner, M., Gasteiger, J., Groß, S., Schnell, F., Freudenthaler, V., and Forkel, R.: Characterization of the Eyjafjallajökull ashplume: Potential of lidar remote sensing, Phys. Chem. Earth, in press, doi:10.1016/j.pce.2011.01.006, 2011.

Winker, D. M. and Osborn, M. T.: Airborne lidar observations of the Pinatubo volcanic plume, Geophys. Res. Lett., 19, 167-170, doi:10.1029/91GL02867, 1992. 